\title{
25. PALYNOSTRATIGRAPHY, PALYNOFACIES, AND THERMAL MATURATION OF CRETACEOUS- PALEOCENE SEDIMENTS FROM THE CÔTE D'IVOIRE-GHANA TRANSFORM MARGIN ${ }^{1}$
}

\author{
Francisca E. Oboh-Ikuenobe, ${ }^{2}$ Oscar Yepes, ${ }^{2,3}$ and Jay M. Gregg ${ }^{2}$
}

\begin{abstract}
Cretaceous to Paleocene sediments from Ocean Drilling Program Sites 959 to 962 in the Côte d'Ivoire-Ghana Transform Margin yield a rich assemblage of dinoflagellate cysts, few acritarchs, spores and pollen, and 12 types of dispersed organic matter. Dinoflagellate cysts proved invaluable in the refinement of shipboard-generated age determinations for Turonian to Paleocene sediments and identification of the Cretaceous/Paleocene boundary at Site 959. A few spore and pollen taxa are of stratigraphic significance. All but two samples of the tectonized basal siliciclastic sediments are barren of dinoflagellate cysts at Sites 959 and 960, but a few samples yield a very low diversity assemblage of spores and pollen. Palynofacies analysis indicates that amorphous organic matter is the dominant organic component in the sediments. However, the tectonized siliciclastic sedments are richer in identifiable terrestrially derived components (wood, black debris, and cuticles) or amorphous organic matter of terrestrial origin. Samples immediately below post-Albian unconformity surfaces at Sites 959 to 961 are enriched in wood and black debris. Thermal alteration indices (TAI) were derived from semiquantitative assessment of spore and pollen colors and used to interpret the thermal maturation of the sediments. TAI values indicate (1) a mature to overmature stage (values $>2.5$, occasionally dark) for the tectonized basal siliciclastic sediments at all four sites; (2) a moderately mature stage (22.5) for some Upper Cretaceous sediments at Sites 959, 960, and 962; and (3) an immature stage (<2) for the rest of the stratigraphic section. The most mature sediments were deposited during the syntransform phase of basin evolution.
\end{abstract}

\section{INTRODUCTION}

During Leg 159, Sites 959 through 962 (Fig. 1) were drilled along the transform passive margin of Côte d'Ivoire-Ghana (CIG). These sites reveal a sedimentary sequence that included Cretaceous to Pliocene strata and helped to obtain stratigraphic and structural information on the area. The data obtained helped to interpret the tectonic and sedimentary processes involved in the creation of the transform margin and its geologic evolution. Additionally, this data helped to recognize the paleoceanographic history of the area (Mascle, Lohmann, Clift, et al., 1996). Site 959 is situated on the flanks of the Deep Ivorian Basin and drilled the most complete stratigraphic record from Albian to Pleistocene sediments. Sites 960, 961, and 962 are located closer to the CIG Marginal Ridge, which is a fossil ridge that connects laterally with the extinct Romanche Fracture Zone (Fail et al., 1970). The stratigraphic sequences drilled in these three sites are marked by hiatuses and condensed sections.

The sedimentation history of the transform margin has been summarized by the Shipboard Scientific Party (1996a). The sedimentary sequences drilled were divided into five lithologic units each at Sites 959 and 960, and three each at Sites 961 and 962 (Shipboard Scientific Party, 1996b-1996e; see Figs. 4-7 for Cretaceous-Paleocene lithologic units, this paper).

This paper focuses on the palynology of Cretaceous to Paleocene sediments at Sites 959 to 962 . Our main objectives are to present the identification of the marine and terrestrial palynomorphs contained in the sediments drilled, and a biostratigraphic subdivision of these sediments, based mainly on their content of dinoflagellate cysts. We also present our interpretation of the origin and depositional environments of the sequences drilled, based on the dispersed organic matter in the sediments, and present a thermal maturation analysis, based on the sporomorph thermal maturation index.

'Mascle, J., Lohmann, G.P., and Moullade, M. (Eds.), 1998. Proc. ODP, Sci. Results, 159: College Station, TX (Ocean Drilling Program).

${ }^{2}$ Department of Geology and Geophysics, University of Missouri-Rolla, Rolla, MO 65409-0410,U.S.A. Oboh-Ikuenobe: foboh@umr.edu

${ }^{3}$ Present address: Department of Geology and Geophysics, Texas A\&M University, College Station, TX 77845

\section{METHODS}

Eighty-six samples were processed from Holes 959D (33 samples), 960A (23), 961A (11), 961B (eight), 962B (four), and 962D (seven). Each sample was macerated and dissolved with $\mathrm{HCl}$ and $\mathrm{HF}$ before the organic matter fraction was separated in heavy liquid (Faegri and Iversen, 1989). Residues used for palynomorph identification were oxidized, sieved, and stained red with safranin. One slide per sample was scanned with transmitted light microscope for dinoflagellate cysts, acritarchs, spores, and pollen; and the abundance of each taxon observed was recorded. At least 300 specimens were counted in samples with very good recovery of dinoflagellate cysts. Several samples were barren of dinoflagellate cysts, whereas spores and pollen were generally rare. Selected palynomorph taxa, in particular those with biostratigraphical value and good preservation, are illustrated in Plates 1 through 10.

Residues used for identification of dispersed organic matter (palynodebris) were not oxidized or sieved because the colors of the organic components were used for identification purposes. This also ensured that amorphous organic matter (AOM) was not removed through sieving. Three hundred particles of palynodebris (each with a minimum size of $5 \mu \mathrm{m}$ ) were counted per slide. Fluorescence light microscopy was used to differentiate between marine-derived and terrestrially derived AOM since the former tends to fluoresce (Lorente, 1990). However, the results obtained are considered as tentative because highly degraded, liptinite-rich terrestrial organic matter types also have a tendency to fluoresce (T. Wagner, pers. comm., 1995). Twelve types of organic matter were identified, using a modified version of the classification system of Jaramillo (1995). They are AOM, marine palynomorphs, terrestrial algae, resins, black debris, yellow-brown fragments, black-brown fragments, cuticles, plant tissue, wood, sporomorphs (spores and pollen), and fungi (Pl. 11, Figs. 1-12). These organic matter types are described in ObohIkuenobe et al. (1997). Details of how thermal maturation indices were derived from colors of spores and pollen can also be found in Oboh-Ikuenobe et al. (1997). Average linkage cluster analysis (Qand R-mode, SYSTAT, 1990-92) was used to interpret the relative abundances of the organic matter components. Cluster analysis was performed on a data matrix of Euclidean correlation coefficients. Al- 
Figure 1. Locations of Sites 959 through 962 in the Côte d'Ivoire-Ghana (CIG) Transform Margin.

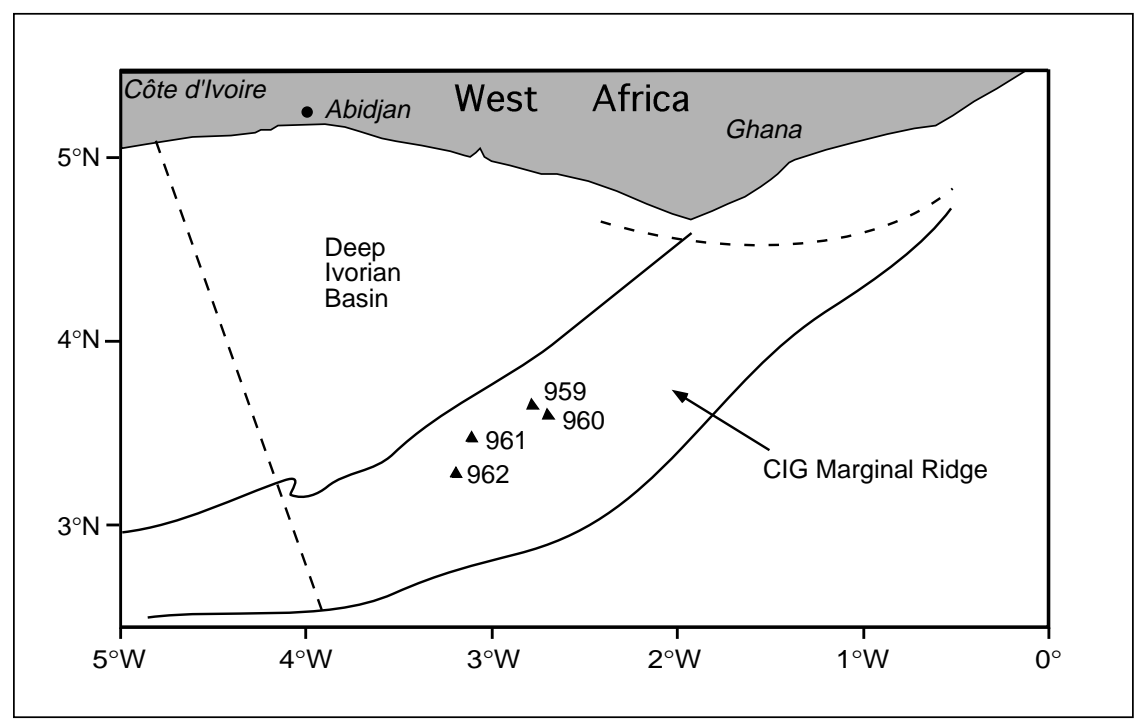

though statistical analysis was performed on data from Cretaceous to Pleistocene samples, only data for the Cretaceous to Paleocene will be discussed in this paper.

\section{BIOSTRATIGRAPHY}

The biostratigraphic interpretations presented for each site are based largely on the dinoflagellate cysts identified in the samples. A total of 152 taxa of dinoflagellate cysts, 10 species of acritarchs, and three species of chlorophytes have been identified at the four sites (see Appendix A). Additionally, 47 sporomorph taxa, 24 of which are illustrated in Plate 10 (Appendix B), are integrated with dinoflagellate cysts for interpretation. Since most of the marine taxa were recovered from Hole 959D (Fig. 2; Pls. 1-9), the discussion of Site 959 is more detailed and organized in ascending chronological order. By contrast, only general biostratigraphic interpretations are made for Sites 960 to 962 on the basis of the sparse occurrences of dinoflagellate cysts.

The Upper Cretaceous from low-latitude areas lack detailed, reliable and globally accepted dinoflagellate cyst zones. For that reason, age determinations in this study are based on comparison with dinoflagellate cyst assemblages described from different Turonian to Danian sections around the world (the oldest sample dated by dinoflagellate cysts in our study was Turonian). The stratigraphic ranges used here for selected dinoflagellate taxa (Fig. 3) are those reported in Williams and Bujak (1985), Helby et al. (1987), and Williams et al. (1993).

\section{Site 959}

Thirty-three samples from Cretaceous to Paleocene sediments in Hole 959D were analyzed (Table 1). Samples from the interval from 1094.26 to 1157.4 m below seafloor (mbsf; 159-959D-72R-3, 6-11 $\mathrm{cm}$, through 78R-6, 70-73 cm) are barren of palynomorphs. These samples were obtained from tectonized siliciclastic sediments of lithologic Unit V, which represents a mature to overmature thermal stage (see "Thermal Maturation Analysis" section). This unit is also barren of planktonic foraminifers and calcareous nannofossils (Shipboard Scientific Party, 1996b). Late Turonian to Danian samples (159-959D-68R-1, 16-19 cm, through 46R-1, 7-12 cm) from lithologic Units III and IV at Hole 959D yield rich assemblages of dinoflagellate cysts (illustrated in Plates 1-9). These lithologic units are comprised of deep marine (bathyal) black claystones, shelf lime- stones, and sandy limestones, respectively (see Fig. 4; Shipboard Scientific Party, 1996b; Oboh-Ikuenobe et al., 1997). With the exception of the claystone with nannofossils at the basal part of Unit III (Core 159-959D-66R), the black claystones from Cores 159-959D-48R to 65R (860.6-1033.7 mbsf) lack planktonic foraminifers and calcareous nannofossils. As a result, this interval was tentatively dated by pollen as Late Cretaceous to Paleocene (Shipboard Scientific Party, 1996b).

Low sedimentation rates in bathyal environments produce condensation in the stratigraphic record. Furthermore, the fossil record of dinoflagellate cysts in bathyal environments most likely reflects a thanatocoenosis of cysts brought together from the shelf by different sedimentary processes, rather than by virtue of having originally lived there collectively. Consequently, the preservation of the fossil record is random for dinoflagellate cysts in bathyal environments. This may be reflected in the stratigraphic record by the recovery of apparently "short-ranging" species (e.g., occurrences of taxa restricted to one sample because of the randomness of the fossil record), and the mixing of taxa because of condensation. There is also the possibility that some of the "short-ranging" species occur in strata between sample points. Only a continuous trench sampling would document all floral horizons.

\section{Late Turonian to Coniacian}

Two samples from lithologic Subunit IVA contain dinoflagellate cysts. Sample 159-959D-68R-1, 16-19 cm (1053.16 mbsf), yields only two specimens of nondiagnostic dinoflagellate cysts. Sample 159-959D-68R-1, 24-25 cm (1053.24 mbsf), located $5 \mathrm{~cm}$ below, was dated early Turonian by shipboard paleontologists based on calcareous nannoplankton. Of the 20 species of dinoflagellates and three acritarchs identified in Sample 159-959D-67R-1, 10-14 cm (1043.40 mbsf), many are long-ranging species, and only three taxa are of stratigraphic importance. Circulodinium vannophorum has its only occurrence at this site in this sample. Since this dinoflagellate cyst has its last occurrence (LO) in Coniacian strata (Williams and Bujak, 1985), its presence here indicates a Coniacian or older age for this sample. A late Turonian to Coniacian age is proposed for this sample based on the presence of $C$. vannophorum together with the first occurrences (FO) of Dinogymnium acuminatum and D. cretaceum. The first appearance of the genus Dinogymnium occurs in upper Turonian to lower Coniacian rocks in Australia (Helby et al., 1987), in the Northern Hemisphere (Williams et al., 1993) and in Venezuela (J. Helenes, pers. comm., 1996). Tricolpites reticulominutus, Tricolpites 
sp. 1, Tricolpites sp. 2, Tricolpites sp. 3, Ephedripites multicostatus, Ephedripites sp. 1, and Monosulcites spp. are some of the sporomorph taxa present in this sample. Jardiné and Magloire (1965) described T. reticulominutus in Maastrichtian rocks in Senegal and Côte d'Ivoire, but noted that similar forms were also recovered from Cenomanian to Turonian rocks. Tricolpites sp. 3 and Monosulcites spp. occur in several Upper Cretaceous and Paleocene samples.

\section{Santonian}

The interval between Samples 159-959D-62R-1, 21-24 cm, and 65R-6, 10-13 cm (995.61-1031.70 mbsf), yields the FO of Dinogymnium undulosum (Sample 159-959D-65R-6, 10-13 cm), the LO of Canningia senonica (Sample 159-959D-64R-5, 89-93 cm) and the only occurrence of the short-ranging and morphologically characteristic Odontochitina porifera (Sample 159-959D-62R-1, 21-24 cm). Dinogymnium undulosum first appears in the lower Santonian rocks in the North Atlantic (Williams and Bujak, 1985) and Venezuela (J. Helenes, pers. comm., 1996). Canningia senonica has a reported stratigraphic range from Cenomanian to Santonian (Williams and Bujak, 1985). The LO of Odontochitina porifera has been reported in the upper Santonian in Colombia (Jaramillo and Yepes, 1994), upper Santonian to lower Campanian rocks in Australia (Helby et al., 1987) and Venezuela (J. Helenes, pers. comm., 1996), and middle Santonian in the North Atlantic (Williams et al., 1993). Based on the above discussion, a Santonian age is assigned to this interval. The LO of $O$. porifera has been used as Site 959's Santonian/Campanian boundary, assuming that the only occurrence of $O$. porifera in Sample 159959D-62R-1, 21-24 cm, corresponds to the LO of this species.

A single specimen of Subtilisphaera zawia has its only occurrence at this site in Sample 159-959D-65R-6, 10-13 cm. The uppermost documented occurrence of this species is in lower Cenomanian rocks (Uwins and Batten, 1988). Below (1981) and Helenes (1984) reported the occurrence of this species in the Albian of Morocco and Baja California (Mexico, respectively. We interpret its occurrence as a reworked specimen from pre-Cenomanian sediments from lithologic Unit V. Circulodinium distinctum and Spiniferites twistringiensis are the dominant species in the dinoflagellate cyst assemblage of this interval. Dinogymnium undulosum and D. acuminatum are common in Sample 159-959D-64R-5, 89-93 cm, which also contained a specimen of the Albian spore Corrugatisporites ivoriensis. In Sample 159959D-63R-6, 2-5 cm (1012.52 mbsf), the relative abundance of dinoflagellate cysts and species diversity decrease with respect to the samples below this depth. Only two species were recovered in this sample: Spiniferites twistringiensis (which predominates) and Palaeohystrichophora infusorioides. Specimens of the acritarch Leiosphaeridia spp. are common in the sample.

Based on poor to moderately preserved calcareous nannoplankton specimens, shipboard paleontologists assigned, tentatively, a late Santonian age for Samples 159-959D-65R-CC (1033.7 mbsf) and 66R-2, 61-62 cm (1035.9 mbsf), and an early Coniacian age for interval 159-959D-66R-7, 19-20 cm, through 66R-CC (1042.9$1043.3 \mathrm{mbsf}$ ). Age assignments based on dinoflagellate cysts and calcareous nannoplankton indicate that the lower Santonian and probably part of the upper Coniacian are represented by a relatively condensed section ( $7 \mathrm{~m}$ of nannofossil claystone) located between the upper Santonian Sample 159-959D-66R-2, 61-62 cm (1035.9 mbsf) and the uppermost lower Coniacian Sample 159-959D-66R-7, 19-20 $\mathrm{cm}$ (1042.9 mbsf). The presence of three phosphatic hardgrounds interbedded with this $7 \mathrm{~m}$ of nannofossil claystone (Shipboard Scientific Party, 1996b) supports a condensed section that may indicate hiatuses due to prolonged history of exposure of the seafloor.

\section{Early Campanian}

Sample 159-959D-60R-4, 94-96 cm (981.54 mbsf), records the FO of Cerodinium sp., and contains few dinoflagellate specimens.
Although the lowermost documented occurrence of species of this genus is Cenomanian (J. Helenes, pers. comm., 1996), there is approximately $15 \mathrm{~m}$ of stratigraphic section below this depth that was not sampled. The pollen Rugulatisporites caperatus, which is present in this sample, occurs in Upper Cretaceous (mainly Campanian to Maastrichtian) sediments in Nigeria (van Hoeken-Klinkenberg, 1964; Salami, 1990). Sample 159-959D-60R-2, 100-104 cm (978.60 mbsf), yields high species diversity and abundance of dinoflagellate cysts, with Trichodinium castanea and Spiniferites cf. S. lenzii as the dominant species. The concurrent presence of T. castanea and Palaeocystodinium lidiae in this sample, below the FO of Areoligera senonensis in Sample 159-959D-60R-4, 94-96 cm, indicates an early Campanian age for this interval.

\section{Late Campanian}

The interval from Sample 159-959D-58R-1, 2-5 cm, to 59R-2, $45-50 \mathrm{~cm}$ (956.82-968.45 mbsf), is dated as late Campanian, based on the LO of Trichodinium castanea and Palaeohystrichophora infusorioides, and the FO of Areoligera senonensis, Cerodinium diebelii and C. leptoderma (see Fig. 2; Helby et al., 1987; Williams et al., 1993). The dinoflagellate cyst Geiselodinium psilatum and the spore Foveotriletes margaritae occur in this interval and in the lower Campanian Sample 159-959D-60R-2, 100-104 cm (978.60 mbsf). This dinoflagellate species is present in the Campanian to Maastrichtian rocks in Senegal (Jain and Millepied, 1973), whereas the spore occurs in Maastrichtian to Paleocene rocks in Nigeria and the Caribbean (Germeraad et al., 1968). The specimens of $F$. margaritae in two Campanian samples (Table 1) may be reworked.

\section{Early Maastrichtian}

The interval between Samples 159-959D-55R-3, 85-88 cm, and 57R-1, 31-34 cm (930.41-947.41 mbsf), is dated as early Maastrichtian, based on the FO of Systematophora placacantha and Spiniferites supparus, and the LO of Hystrichodinium pulchrum (Fig. 2). Areoligera coronata has its lowermost occurrence in the section in Sample 159-959D-57R-1, 31-34 cm (947.41 mbsf).

\section{Late Maastrichtian}

Samples 159-959D-49R-4, 99-102 cm, to 54R-1, 37-39 cm (875.69-918.47 mbsf), yield stratigraphically significant taxa that are used to assign a late Maastrichtian age to this interval. Sample 159-959D-54R-1, 37-39 cm (918.47 mbsf), yields the FO of Manumiella raijae and Cordosphaeridium fibrospinosum. The first fossil record of $C$. fibrospinosum is documented in uppermost lower Maastrichtian rocks in the North Atlantic (Williams et al., 1993). M. raijae occurs in uppermost lower Maastrichtian to upper Maastrichtian sediments in Sweden (Kjellström, 1973), and Maastrichtian rocks in Morocco (Rauscher and Doubinger, 1982). Spiniferites fluens has its lowermost occurrence in the section in Sample 159-959D-54R-1, $37-39 \mathrm{~cm}$ (918.47 mbsf). This species is present in the upper Maastrichtian rocks in the Atlantic Coastal Plain of the United States. (Habib and Miller, 1989), Maastrichtian to Danian rocks in Denmark (Hansen, 1977), Maastrichtian rocks in Baja California, Mexico (Helenes, 1984), upper Maastrichtian to Danian rocks in South Scandinavia (Hultberg, 1985), and lower Maastrichtian to Paleocene rocks in Morocco (Soncini and Rauscher, 1988).

The eight samples analyzed in the interval 159-959D-49R-4, 99$102 \mathrm{~cm}$, through 53R-4, 67-70 cm (875.69-912.46 mbsf), contain the FO of Cerodinium speciosum, Cyclapophysis monmouthensis, Manumiella seelandica, Pierceites pentagona, Kenleyia leptocerata, Kenleyia sp. A, K. cf. K. lophophora, Cribroperidinium wetzelii, Diphyes colligerum, Thalassiphora pelagica, Palaeocystodinium australinum, Cordosphaeridium inodes, Cordosphaeridium exilimurum, Glaphyrocysta perforata, Cyclonephelium? castelcasiense, and 


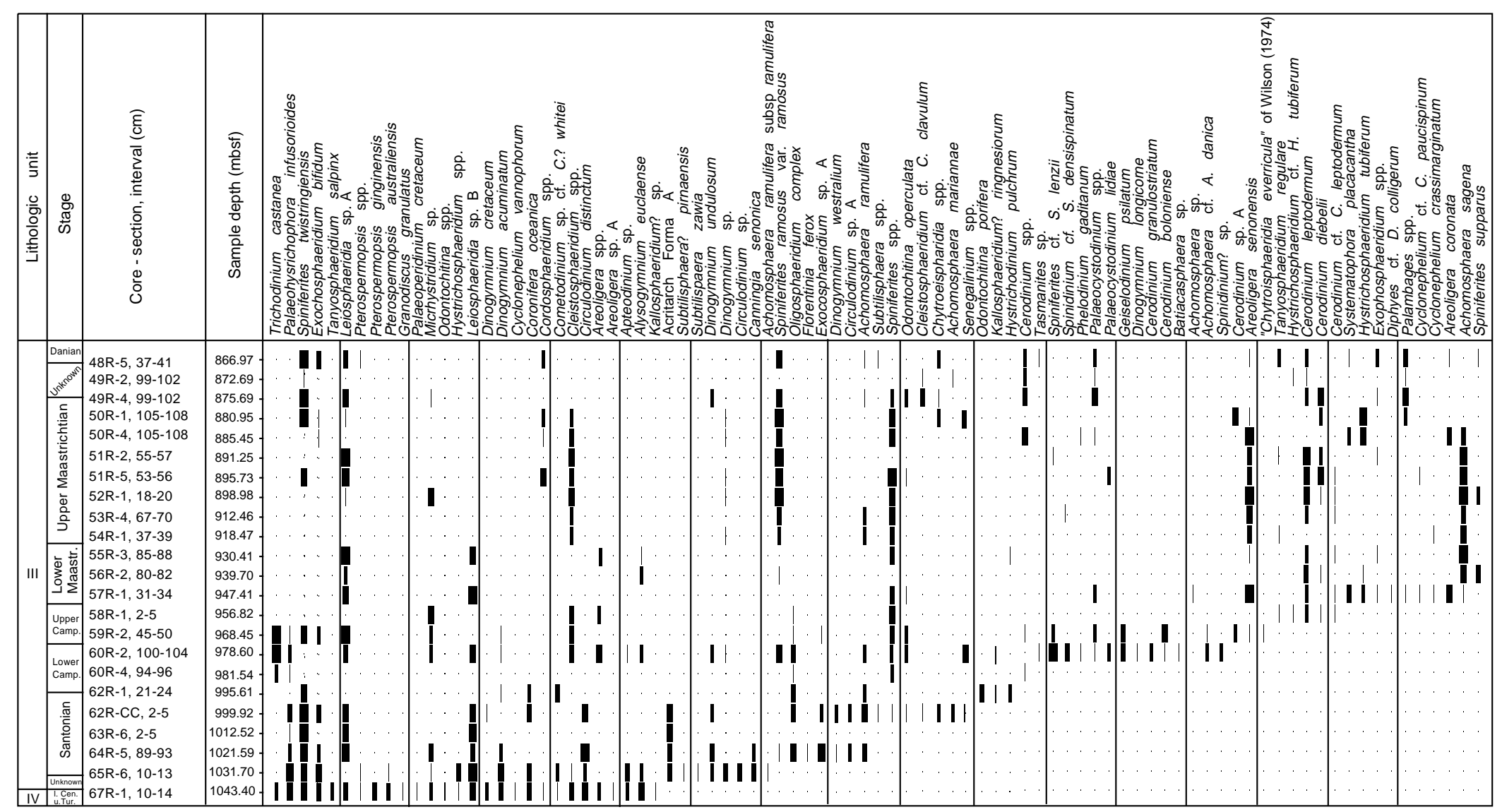

Figure 2. Range chart of phytoplankton species from Site 959. At least 300 specimens per slide were counted in samples with very good recovery. In samples with poorer recovery, the entire slide was scanned. 


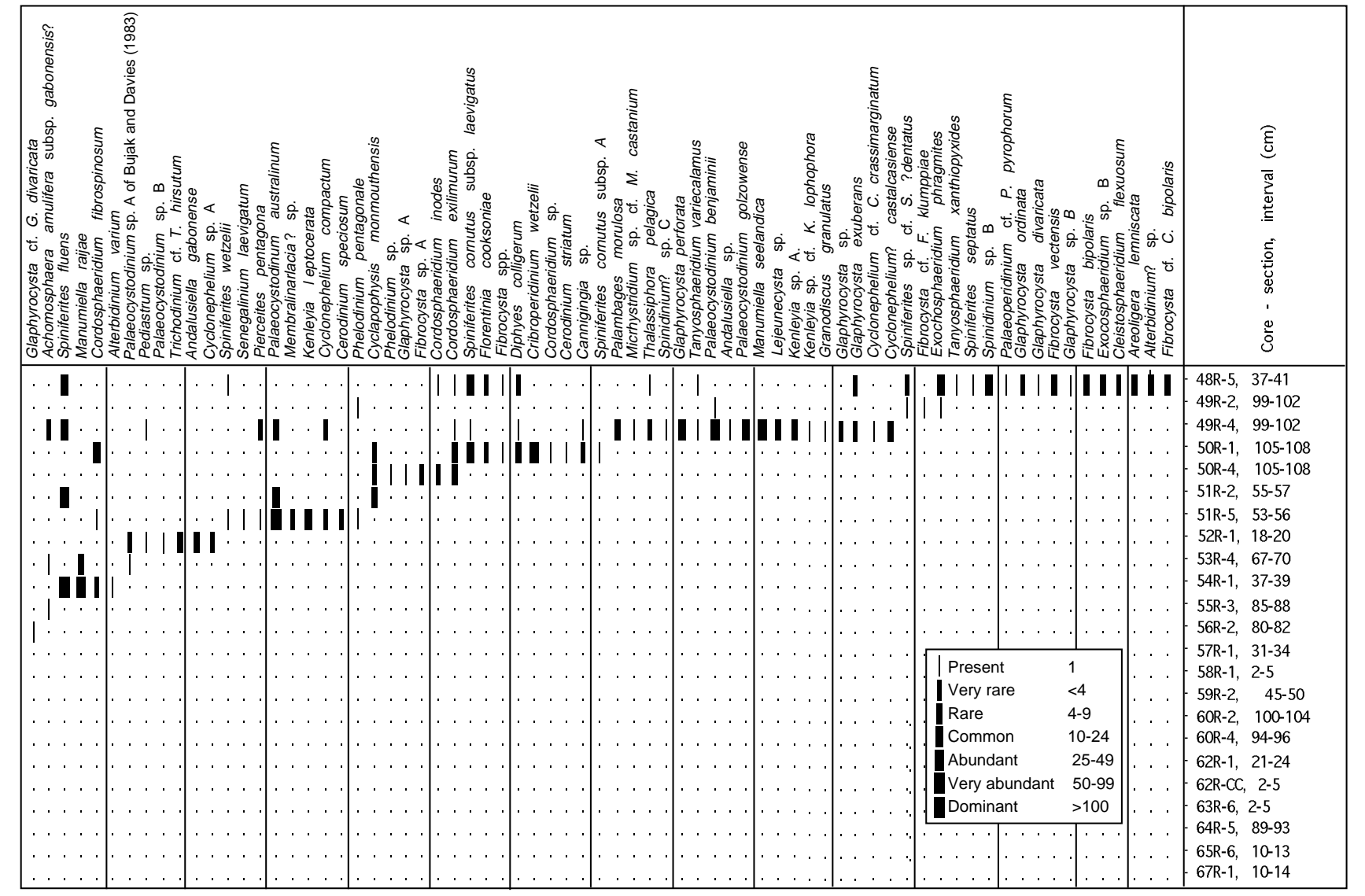

Figure 2 (continued). 


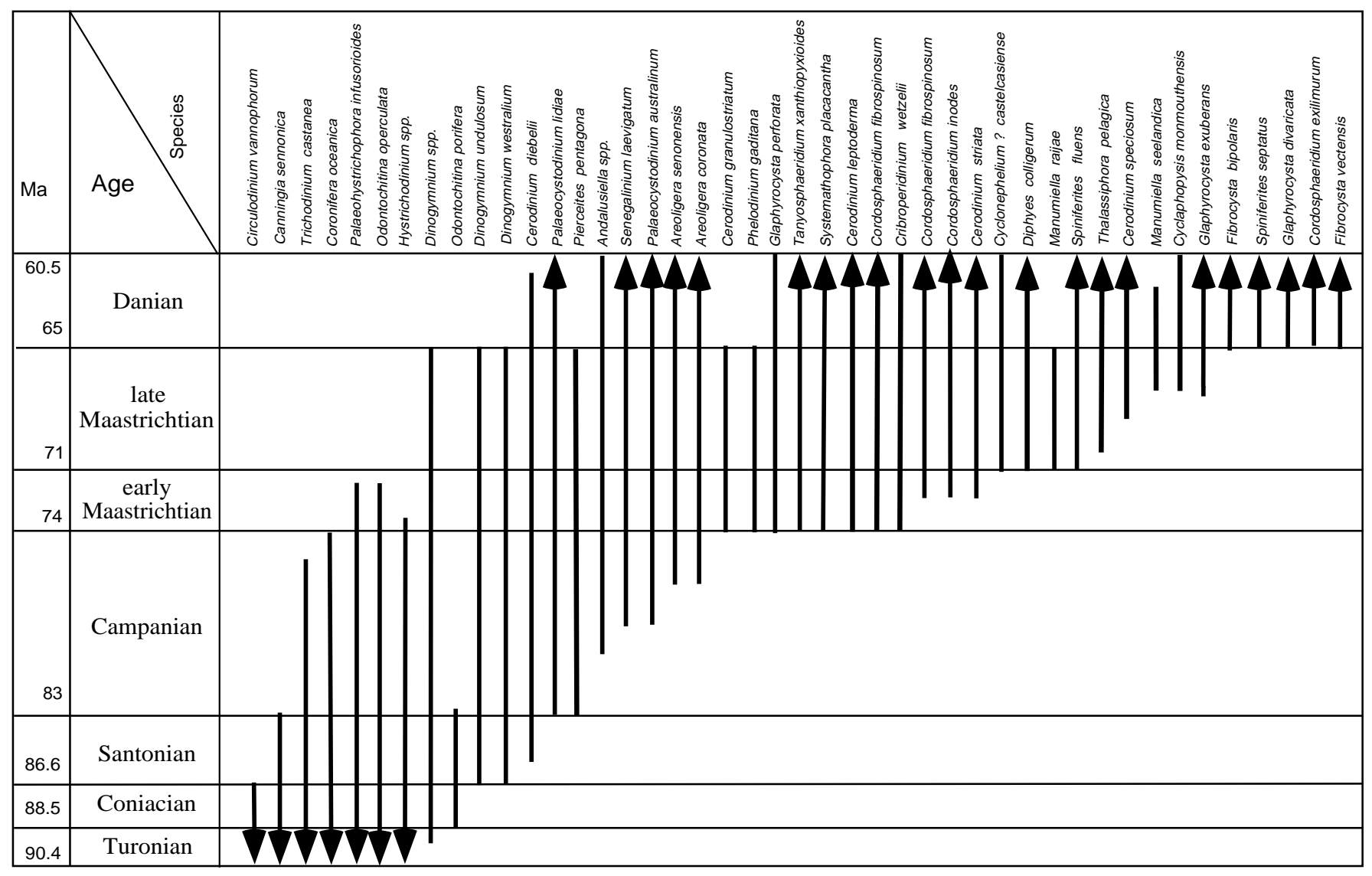

Figure 3. Stratigraphic ranges of selected dinoflagellate cysts from Site 959.

Palambages morulosa, in co-occurrence with Dinogymnium spp. Sample 159-959D-49R-4, 99-102 cm (875.69 mbsf), records the LO of Dinogymnium undulosum. The last fossil record of Dinogymnium spp. is found worldwide in uppermost Maastrichtian rocks, before the Maastrichtian/Danian boundary.

The first documented occurrences of Cyclapophysis monmouthensis and Manumiella seelandica are in uppermost Maastrichtian rocks elsewhere (Benson, 1976; Hansen, 1977; Koch and Olsson, 1977; Wilson, 1978; Firth, 1987; Helby et al., 1987; Brinkhuis and Leereveld, 1988). Pierceites pentagona has not been recovered above the Maastrichtian/Danian boundary (Firth, 1987). Other common taxa in this interval include P. australinum, C. exilimurum, and $C$. inodes.

\section{Latest Maastrichtian to Danian}

Sample 159-959D-49R-4, 99-102 cm (875.69 mbsf), which yields the LO of Dinogymnium spp. and Pierceites pentagona, probably marks the top of the upper Maastrichtian interval. As mentioned above, these species have not been recovered above the Maastrichtian/Danian boundary elsewhere. This sample also yields the only occurrence of Manumiella seelandica. Its relative abundance of $10 \%$ in this sample is high in comparison with the other taxa in the assemblage. The abundance of $M$. seelandica is a significant stratigraphic event at the Maastrichtian/Danian boundary. The relatively high abundance of this species correlates well with abundance events of the same species just below the Maastrichtian/Danian boundary in Georgia (Firth, 1987), in the Middle Waipara River Section in New Zealand (Helby et al., 1987), and within the Fish Clay boundary in Denmark (Hultberg, 1986). The abundance of this species above the
Maastrichtian/Danian boundary at the Woodside Creek section in New Zealand (Wilson, 1978) was reinterpreted by Helby et al. (1987) as representing mixing of ages in a condensed section at the boundary.

Other stratigraphically significant species that have their first and only occurrences in Sample 159-959D-49R-4, 99-102 cm, are Glaphyrocysta perforata, Cyclonephelium? castelcasiense and Thalassiphora pelagica. The FO of $G$. perforata is documented in upper Maastrichtian rocks from south Scandinavia (Hultberg, 1985), Maastrichtian rocks in Sweden and Denmark (Hultberg and Malmgren, 1987), Maastrichtian rocks in New Jersey (Koch and Olsson, 1977), Maastrichtian rocks in Venezuela (D.T. Pocknall, pers. comm., 1996). Cyclonephelium? castelcasiense can also be found in Maastrichtian rocks in Germany (Marheinecke, 1992). De Coninck and Smit (1982) reported a species with a strong morphological similarity to Cyclonephelium? castelcasiense in the Maastrichtian/Danian transition of Spain (as Glaphyrocysta sp. cf. Cyclonephelium castelcasiense). The lowest occurrence of $T$. pelagica has been documented in upper Maastrichtian rocks (Wilson, 1974; Hansen, 1977; Firth, 1987; Williams et al., 1993), and in lower to uppermost lower Maastrichtian rocks (Williams and Bujak, 1985; Firth, 1993). The pollen Tricolpites reticulominutus, which is present in this sample, occurs in upper Maastrichtian rocks in Senegal and Côte d'Ivoire (Jardiné and Magloire, 1965).

The FO of the lower latitude dinoflagellate Kenleyia spp. (see Pl. 5, Figs. 6-8, Pl. 7, Figs. 4-9) has been reported in upper Maastrichtian sediments where they are not common. They do, however, become more common in Danian sediments at lower latitudes, but are absent at higher latitudes (H. Brinkhuis, pers. comm., 1996). The FO of $K$. leptocerata is recorded in Sample 159-959D-51R-5, 53-56 cm 
Table 1. List of samples, sample depths, recovery of dinoflagellate cysts and acritarchs, and pollen and spores identified in Hole 959D.

\begin{tabular}{|c|c|c|c|c|}
\hline $\begin{array}{l}\text { Core, section, } \\
\text { interval }(\mathrm{cm})\end{array}$ & $\begin{array}{l}\text { Depth } \\
\text { (mbsf) }\end{array}$ & $\begin{array}{l}\text { Dinoflagellate cysts } \\
\text { and acritarchs }\end{array}$ & Pollen and spores & Remarks \\
\hline \multicolumn{5}{|l|}{ 159-959D- } \\
\hline 46R-1, 7-12 & 841.37 & Good recovery & & Danian \\
\hline $47 \mathrm{R}-1,66-69$ & 851.56 & Good recovery & $\begin{array}{l}\text { Monosulcites spp. } \\
\text { Granulatisporites sp. }\end{array}$ & Danian \\
\hline $48 \mathrm{R}-5,37-41$ & 866.97 & Very good recovery & $\begin{array}{l}\text { Buttinia andreevi } \\
\text { Longapertites vaneendenburgi } \\
\text { Laevigatosporites gracilis } \\
\text { Leiotriletes } \text { spp. } \\
\text { Tricolporopollenites spp. } \\
\text { Arecipites sp. } \\
\text { Monosulcites } \text { spp. }\end{array}$ & Danian \\
\hline 49R-2, 99-102 & 872.69 & Poor recovery & Monosulcites spp. & \\
\hline $49 \mathrm{R}-4,99-102$ & 875.69 & Very good recovery & $\begin{array}{l}\text { Parvisaccites cf. P. radiatus } \\
\text { Tricolpites reticulominutus } \\
\text { Tricolpites } \mathrm{sp} .3 \\
\text { Tricolpites } \mathrm{sp} .4 \\
\text { Monosulcites } \mathrm{spp} . \\
\text { Monocolpopollenites } \mathrm{sp} . \\
\text { Toroisporis sp. } \\
\text { Laevigatosporites gracilis }\end{array}$ & late Maastrichtian \\
\hline $50 \mathrm{R}-1,105-108$ & 880.95 & Very good recovery & Foveotricolpites sp. & late Maastrichtian \\
\hline $50 \mathrm{R}-4,105-108$ & 885.45 & Very good recovery & & late Maastrichtian \\
\hline $51 \mathrm{R}-2,55-57$ & 891.25 & Very good recovery & & late Maastrichtian \\
\hline 51R-5, 53-56 & 895.73 & Very good recovery & & late Maastrichtian \\
\hline $52 \mathrm{R}-1,18-20$ & 898.98 & Very good recovery & $\begin{array}{l}\text { Corollina? sp. } \\
\text { Triporopollenites sp. }\end{array}$ & late Maastrichtian \\
\hline $53 \mathrm{R}-4,67-70$ & 912.46 & Moderate recovery & Tricolpites sp. 3 & late Maastrichtian \\
\hline $54 \mathrm{R}-1,37-39$ & 918.47 & Very good recovery & & late Maastrichtian \\
\hline $55 \mathrm{R}-3,85-88$ & 930.41 & Good recovery & $\begin{array}{l}\text { Deltoidospora sp. } \\
\text { Dicolpites sp. }\end{array}$ & early Maastrichtian \\
\hline $56 \mathrm{R}-2,80-82$ & 939.70 & Poor recovery & & early Maastrichtian \\
\hline $57 \mathrm{R}-1,31-34$ & 947.41 & Good recovery & & early Maastrichtian \\
\hline $58 \mathrm{R}-1,2-5$ & 956.82 & Poor recovery & Monosulcites spp. & late Campanian \\
\hline $59 \mathrm{R}-2,45-50$ & 968.45 & Very good recovery & $\begin{array}{l}\text { Monosulcites spp. } \\
\text { Foveotriletes margaritae }\end{array}$ & late Campanian \\
\hline $60 \mathrm{R}-2,100-104$ & 978.60 & Very good recovery & $\begin{array}{l}\text { Foveotriletes margaritae } \\
\text { Deltoidospora } \mathrm{sp} \text {. }\end{array}$ & early Campanian \\
\hline $60 \mathrm{R}-4,94-96$ & 981.54 & Poor recovery & $\begin{array}{l}\text { Rugulatisporites caperatus } \\
\text { Striamonocolpites } \mathrm{sp} \text {. }\end{array}$ & early Campanian \\
\hline $62 \mathrm{R}-1,21-24$ & 995.61 & Poor recovery & Tricolporopollenites spp. & Santonian \\
\hline 62R-CC, $2-5$ & 999.92 & Very good recovery & Ephedripites sp. 3 & Santonian \\
\hline $63 \mathrm{R}-6,2-5$ & 1012.52 & Good recovery & & Santonian \\
\hline $64 \mathrm{R}-5,89-93$ & 1021.59 & Good recovery & $\begin{array}{l}\text { Proxapertites? sp. } \\
\text { Corrugatisporites ivoriensis }\end{array}$ & Santonian \\
\hline $65 \mathrm{R}-6,10-13$ & 1031.70 & Very good recovery & $\begin{array}{l}\text { Ephedripites } \text { sp. } 1 \\
\text { Ephedripites } \mathrm{sp} .3 \\
\text { Monosulcites } \mathrm{spp} . \\
\text { Tricolpites } \text { sp. } 3 \\
\text { Arecipites } \mathrm{sp} .\end{array}$ & Santonian \\
\hline $67 \mathrm{R}-1,10-14$ & 1043.40 & Good recovery & $\begin{array}{l}\text { Tricolpites reticulominutus } \\
\text { Tricolpites } \mathrm{sp} .1 \\
\text { Tricolpites } \mathrm{sp} .2 \\
\text { Tricolpites } \mathrm{sp} .3 \\
\text { Ephedripites multicostatus } \\
\text { Ephedripites } \mathrm{sp} .1 \\
\text { Tricolporopollenites } \mathrm{spp} . \\
\text { Verrutriletes } \mathrm{sp} . \\
\text { Monosulcites } \mathrm{spp} .\end{array}$ & late Turonian-Coniacian \\
\hline 68R-1, 16-19 & 1053.16 & Very poor recovery & Barren & late Turonian-Coniacian \\
\hline 72R-3, 6-11 & 1094.26 & Barren & Barren & \\
\hline $74 \mathrm{R}-2,79-83$ & 1112.79 & Barren & Barren & \\
\hline $75 \mathrm{R}-1,65-69$ & 1120.85 & Barren & Barren & \\
\hline $76 \mathrm{R}-2,49-53$ & 1131.79 & Barren & Barren & \\
\hline 76R-CC, $0-4$ & 1132.23 & Barren & Barren & \\
\hline $78 \mathrm{R}-5,70-73$ & 1155.90 & Barren & Barren & \\
\hline $78 \mathrm{R}-6,70-73$ & 1157.40 & Barren & Barren & \\
\hline
\end{tabular}

Notes: The dinoflagellate cyst and acritarch taxa recovered in this hole can be found in Figure 2 . The categories of recovery are as follows: very poor $=1-5$ specimens per slide, poor $=5-50$, moderate $=50-100$, good $=100-300$, very good $=>300$. For pollen and spores, single specimens were recovered with the exception of Tricolpites sp. 2, Tricolpites sp. 3 , Monosulcites spp., and Ephedripites spp.

(895.73 mbsf). Kenleyia spp. are common in Sample 159-959D-49R$4,99-102 \mathrm{~cm}$ (875.69 mbsf). We believe that the common co-occurrence of Kenleyia spp. with well-known uppermost Maastrichtian dinoflagellate cysts (e.g., Dinogymnium spp. and Pierceites pentagona) represents a condensed Maastrichtian to Danian section in Sample 159-959D-49R-4, 99-102 cm (875.69 mbsf). Condensation due to low sedimentation rates can be found associated with bathyal environments of deposition, like those proposed for the black claystones of lithologic Unit III from benthic foraminifers and the pres- ence of Zoophycos ichnofacies (Shipboard Scientific Party, 1996b; Kuhnt et al., 1996; Oboh-Ikuenobe et al., 1997). The presence of glauconite in this part of the section (Fig. 4) also supports this interpretation. Although the higher percentage of nonfluorescing amorphous organic matter seems contradictory, an increase in terrestrially derived organic matter (wood, black debris, and black-brown fragments) is probably indicative of a drop in sea level just below the Cretaceous/Paleocene boundary (see "Palynofacies Analysis" section). 

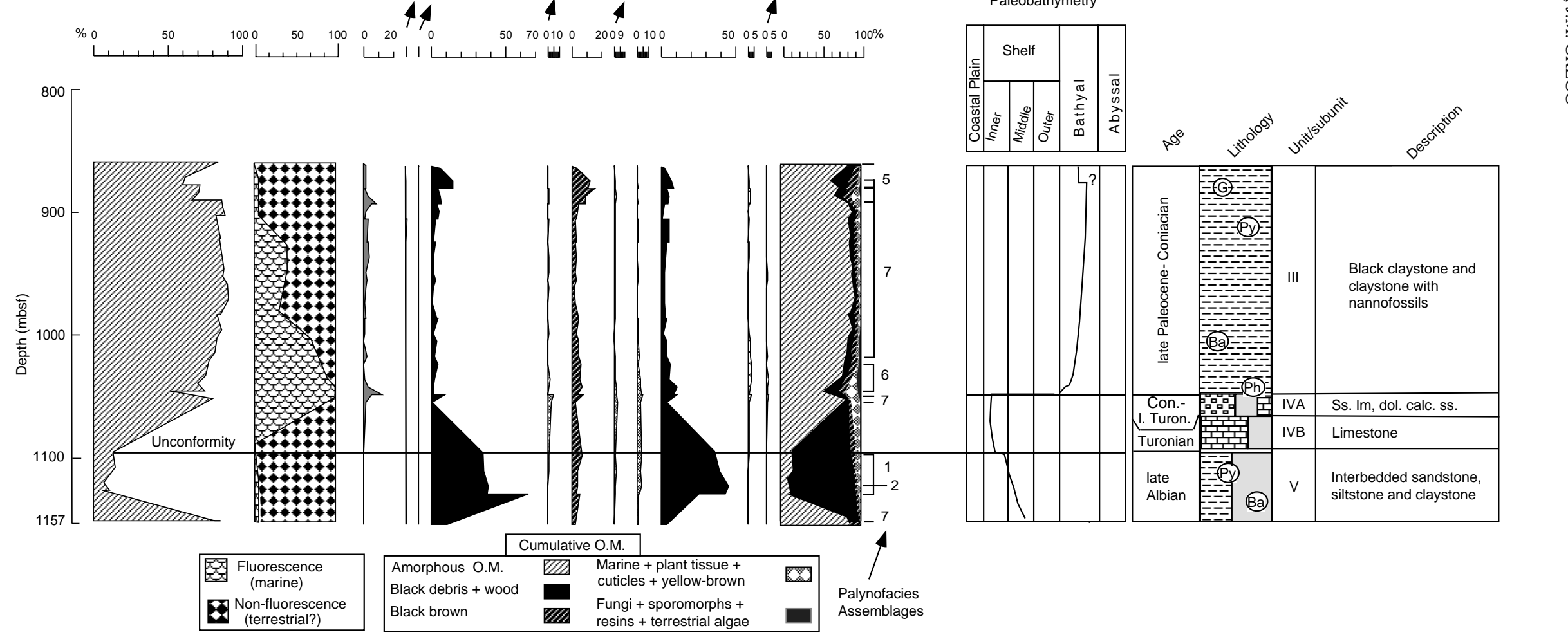

Figure 4. Composite chart of data at Site 959 showing the percent distribution of dispersed organic matter, cumulative organic matter types derived from R-mode cluster analysis, sample positions of palynofacies assemblages, reconstructed paleobathymetric curve and lithofacies. Fluorescence analysis is used to separate the marine and possibly terrestrial fractions of AOM. In the lithofacies column, Py = pyrite; $\mathrm{G}$ $=$ glauconite; $\mathrm{Ba}=$ barite nodule; $\mathrm{Ph}=$ phosphatic hardground. The current water depth at this site is $2100 \mathrm{~m}$ (modified from Oboh-Ikuenobe et al., 1997). Age assignments and lithology for lithologic Subunit IVB and Unit V are taken from Shipboard Scientific Party (1996b). 
Sample 159-959D-49R-2, 99-102 cm (872.69 mbsf), yields a poor assemblage of dinoflagellate cysts, and none of the taxa is stratigraphically diagnostic. Core 159-959D-49R was dated as late Maastrichtian by Kuhnt et al. (1996) on the basis of benthic foraminifers, and by Shipboard Scientific Party (1996b) because of the presence of Buttinia andreevi (see statement about this pollen below) in the core catcher (Section 49R-CC).

Sample 159-959D-48R-5, 37-41 cm (866.97 mbsf), is dated as Danian, based on the FO of Spiniferites septatus, Fibrocysta bipolaris, Fibrocysta vectensis, the co-occurrence of Cerodinum diebelii, and the absence of typical Maastrichtian species, such as Dinogymnium spp. and Pierceites pentagona. The absence of Manumiella seelandica, which ranges from upper Maastrichtian to lower Danian, suggests that part of the lowermost Danian is below Sample 159959D-48R-5, 37-41 cm (866.97 mbsf). Based on the above discussion we have placed the Maastrichtian/Danian boundary between Samples 159-959D-48R-5, 37-41 cm (866.97 mbsf), and 159-959D49R-4, 99-102 cm (875.69 mbsf), being perhaps represented by a condensed interval in Sample 159-959D-49R-4, 99-102 cm (875.69 mbsf).

Longapertites vaneendenburgi and Buttinia andreevi occur in Sample 159-959D-48R-5, 37-41 cm. L. vaneendenburgi has been reported in Maastrichtian to Danian rocks in Nigeria and the Caribbean (Germeraad et al., 1968). On the other hand, B. andreevi has a known LO in uppermost Maastrichtian rocks (Jardiné and Magloire, 1965; Germeraad et al., 1968). The presence of a poorly preserved specimen of this pollen in this sample (Pl. 10, Fig. 24) indicates that either (1) the specimen is reworked, although there is no other evidence from dinoflagellate cysts or lithologic features to support this hypothesis, or (2) B. andreevi probably ranges into the Danian. Sample 159959D-44R-3, 72-73 cm (825.6 mbsf), is dated as late Paleocene based on calcareous nannofossils (Shipboard Scientific Party, 1996b).

\section{Site 960}

Twenty-three samples were analyzed from Hole 960A. Among the lithologies sampled were glauconitic claystone from lithologic Subunit IVA at 159-960A-21R-1, 43-48 cm (184.53 mbsf), and the siliciclastics of Subunits VA and VB from interval 159-960A-37R-2, 1-4 cm, through 61R-1, 19-21 cm (interval 329.34-446.39 mbsf; see Fig. 5 for lithology). According to Shipboard Scientific Party (1996c), sediments below Section 159-960A-21R-CC (193.8 mbsf) are barren of calcareous nannoplankton and planktonic foraminifers. A majority of the samples we analyzed are barren of dinoflagellate cysts, and have very poor recovery of spores and pollen (Table 2).

Sample 159-960A-21R-1, 43-48 cm (184.53 mbsf), contains an Upper Cretaceous assemblage of dinoflagellate cysts, with abundant occurrences of Palaeohystrichophora infusorioides (45\%) and Dinogymnium spp. (25\%). The co-occurrence of Isabelidinium cooksoniae, Dinogymnium undulosum, and $P$. infusorioides indicates an age not younger than early Maastrichtian but not older than Santonian for this sample. Chenopodipollis sp. is the only pollen present in this sample. Lithologic Subunit IVA was interpreted as a condensed Coniacian to Maastrichtian section by Shipboard Scientific Party (1996c). Sample 159-960A-42R-2, 35-38 cm (355.35 mbsf), from Subunit VA yields a single occurrence of Cerodinium sp. This genus is not older than Cenomanian. One poorly preserved specimen of the Upper Cretaceous pollen Buttinia andreevi occurs in Sample 159960A-53R-2, 29-32 cm (404.59 mbsf). The presence of this palynomorph taxa in Subunit VA suggests a Late Cretaceous age, which is not in agreement with the assignment of a pre-Turonian age for the tectonized basal siliciclastic sediments (Shipboard Scientific Party, $1996 \mathrm{c}$ ). Its presence here is probably due to caving during sample drilling operations. The lowermost sample from Subunit VB (159-
960A-61R-1, 19-21 cm; $446.39 \mathrm{mbsf}$ ) contains the bisaccate pollen Parvisaccites cf. P. radiatus, which is common in Aptian to Cenomanian sediments (Brenner, 1963; Kemp, 1970).

\section{Site 961}

Nineteen core samples were analyzed from the site. Eleven samples were obtained from Hole 961A, from the interval from 167.75 to 305.32 mbsf (159-961A-19R-1, 35-38 cm, through 34R-2, 32-37 $\mathrm{cm})$. These samples were obtained from zeolite claystone and glauconite-rich porcellanite from Subunit IIB, and siliciclastic sediments from Unit III (see Fig. 6 for lithology). Eight samples were analyzed from Unit III in Hole 961B, from 323.08 to 369.91 mbsf (interval 159-961B-12R-1, 68-71 cm, through 19R-CC, 1-3 cm). The samples are barren of dinoflagellate cysts but contain a few spores and pollen (Table 3). The interval between Cores 159-961A-19R and 20R is dated late Paleocene on the basis of calcareous nannofossils and benthic foraminifers (Shipboard Scientific Party, 1996d). Unit III is generally barren of calcareous nannoplankton and planktonic foraminifer, although it has been assigned an early Cenomanian to late Albian age (J. Mascle, per. comm., 1996). The presence of very poorly preserved specimens of the long-ranging nannofossil Watznaueria barnesae (Bajocian-Maastrichtian age) in core-catcher samples from Cores 159-961B-9R (313.2 mbsf) and 11R (322.4 mbsf) is documented by Shipboard Scientific Party (1996d). All eight Unit III samples analyzed in Hole 961B are below $313.2 \mathrm{mbsf}$ and are barren of dinoflagellate cysts. However, they contain specimens of the long-ranging pollen Ephedripites spp., Cyathidites minor, and Monosulcites sp., which are common in Aptian to Cenomanian rocks (Brenner, 1963; Kemp, 1970; Kotova, 1978).

\section{Site 962}

Eleven samples were analyzed from this site. They were obtained from palygorskite claystone of Subunit IIB at $64.9 \mathrm{mbsf}$ (interval 159-962B-8H-1, 40-45 cm), chert and porcellanite of Subunit IIC from the interval from 72.61 to 94.33 mbsf (159-962B-8H-6, 61-66 $\mathrm{cm}$, through $13 \mathrm{X}-\mathrm{CC}, 3-5 \mathrm{~cm})$, and alternating tectonized siliciclastic and carbonate-bearing sediments of Unit III from the interval from 191.23 to 393.81 mbsf (159-962D-13R-1, 23-25 cm, through 37R-4, $81-84 \mathrm{~cm})$. These lithologies are shown in Figure 7. Table 4 lists the palynomorphs contained in the samples.

Three of the four samples analyzed in Hole 962B yield a very poor assemblage of dinoflagellate cysts. An age not older than late Albian is indicated for Sample 159-962B-13X-CC, 3-5 cm (94.33 mbsf), based on the presence of Palaeohystrichophora infusorioides, which has its lowermost documented occurrence in upper Albian sediments (Fig. 3). Williams et al. (1993) reported the FO of $P$. infusorioides in lower Cenomanian sediments in the Northern Hemisphere. This is in agreement with Clarke and Verdier (1967) who erected the Hystrichosphaeridium siphoniphorum Zone of Cenomanian to Turonian? age, the base of which is defined by the FO of $P$. infusorioides. However, Below (1984) reported the FO of $P$. infusorioides below the base ranges of well-known upper Albian dinoflagellate cysts from onshore sections in Morocco. Helby et al. (1987) recorded the base stratigraphic range of $P$. infusorioides in the upper part of the Xenascus asperatus Zone, which they indicated was Vraconian (late Albian) in age.

Sample 159-962B-9H-1, 69-73 cm (74.69 mbsf), yields a dinoflagellate cyst assemblage dominated by Palaeohystrichophora infusorioides (68\% of 107 taxa in one slide). An age not older than Cenomanian and not younger than late Campanian is assigned to this core sample, based on the co-occurrence of Cerodinium sp., Trichodinium castanea, and Palaeohystrichophora infusorioides. The latter has its uppermost documented occurrence in lower Maastrichtian rocks, 


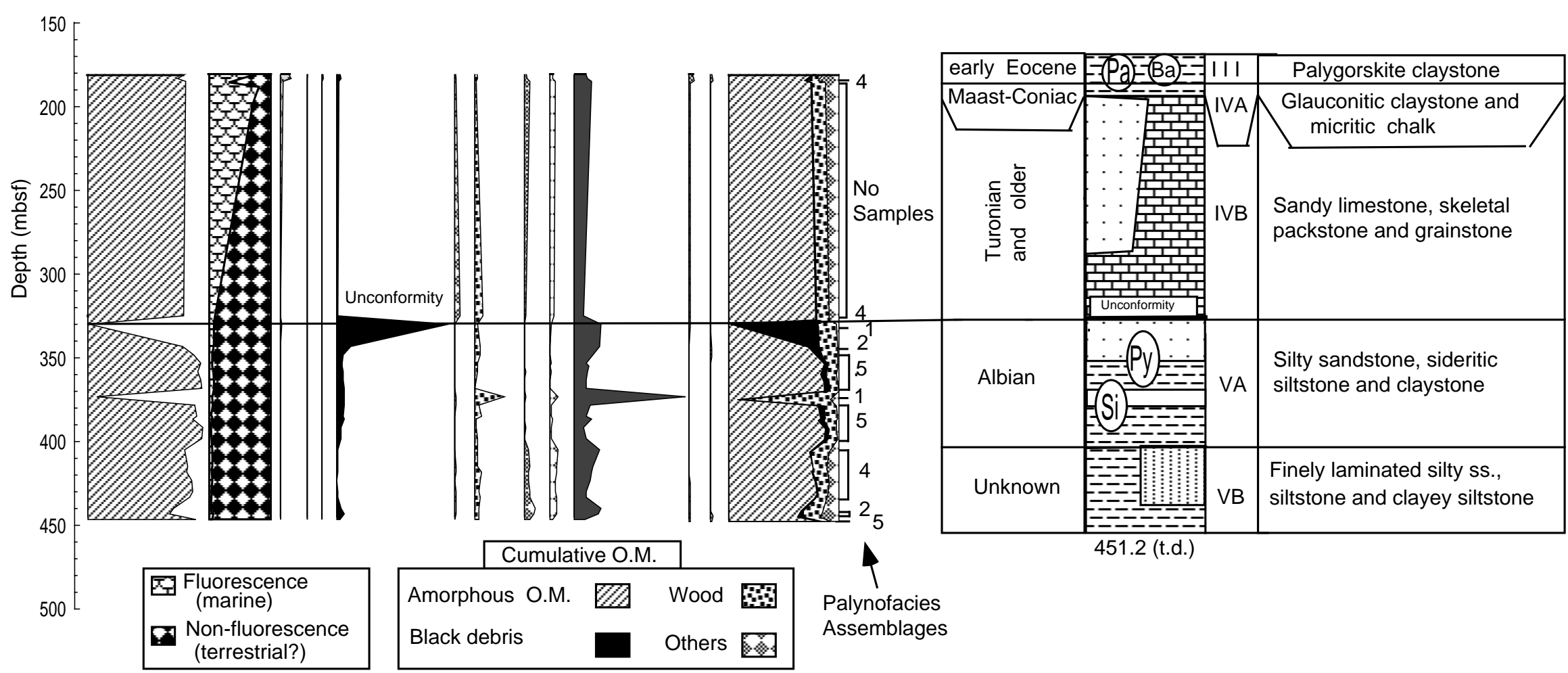

Figure 5. Percent distribution of dispersed organic matter at Site 960, including the fluorescence analysis of AOM, cumulative organic matter types derived from R-mode cluster analysis, sample positions of palynofacies assemblages, and lithofacies. In the lithofacies column, $\mathrm{Py}=$ pyrite; $\mathrm{Pa}=$ palygorskite claystone; $\mathrm{Ba}=$ barite nodule; $\mathrm{Si}=$ silica. The current water depth at this site is $2061 \mathrm{~m}$ (modified from ObohIkuenobe et al., 1997). Because of poor recovery of palynomorphs at this site, age assignments and lithology for all three lithologic Units shown (III through V) are taken from Shipboard Scientific Party (1996c). 
Table 2. List of samples, sample depth, and palynomorphs identified in Hole 960A.

\begin{tabular}{|c|c|c|c|c|}
\hline $\begin{array}{l}\text { Core, section, } \\
\text { interval }(\mathrm{cm})\end{array}$ & $\begin{array}{l}\text { Depth } \\
\text { (mbsf) }\end{array}$ & $\begin{array}{l}\text { Dinoflagellate cysts } \\
\text { and acritarchs }\end{array}$ & Pollen and spores & Remarks \\
\hline $\begin{array}{l}\text { 159-960A- } \\
\text { 21R-1, 43-48 }\end{array}$ & 184.53 & $\begin{array}{l}\text { Palaeohystrichophora infusorioides (120) } \\
\text { Achomosphaera ramosus subsp. ramosus (6) } \\
\text { Dinogymnium undulosum (25) } \\
\text { Cerodinium? sp. } \\
\text { Spinidinum sp. } \\
\text { Dinogymnium acuminatum (36) } \\
\text { Dinogymnium sp. } \\
\text { Fibrocysta } \text { sp. (5) } \\
\text { Spiniferites ramosus subsp. multibrevis } \\
\text { Isabelidinium cooksoniae (3) } \\
\text { Exocosphaeridium sp. } \\
\text { Alisogymniun euclaense (6) } \\
\text { Spiniferites ramosus subsp. ramosus (15) } \\
\text { Leiosphaeridia } \text { sp. (15) }\end{array}$ & Chenopodipollis sp. & $\begin{array}{l}\text { Not younger than early Maastrichtian, not older than Santonian } \\
\text { Maastrichtian, not older than Santonian }\end{array}$ \\
\hline $37 \mathrm{R}-2,1-4$ & 329.34 & Barren & Barren & \\
\hline $38 \mathrm{R}-4,22-26$ & 342.92 & Barren & Barren & \\
\hline $40 \mathrm{R}-1,31-34$ & 348.61 & Manumiella? sp. & Multiporopollenites sp. 2 & \\
\hline $41 \mathrm{R}-2,18-21$ & 352.68 & Acritarch forma A & Barren & Pediastrum sp. \\
\hline $42 \mathrm{R}-2,35-38$ & 355.35 & $\begin{array}{l}\text { Cerodinium } \mathrm{sp} . \\
\text { Spiniferites ramosus subsp. multibrevis }\end{array}$ & Barren & Not older than Cenomanian \\
\hline $43 \mathrm{R}-1,75-80$ & 358.25 & Barren & Barren & \\
\hline $44 \mathrm{R}-2,24-28$ & 364.04 & Barren & Barren & \\
\hline $45 \mathrm{R}-2,21-25$ & 368.91 & Barren & Barren & \\
\hline $46 \mathrm{R}-2,29-32$ & 373.59 & Barren & Barren & \\
\hline $47 \mathrm{R}-1,81-86$ & 377.61 & Barren & Barren & \\
\hline $48 \mathrm{R}-4,64-68$ & 384.44 & Barren & Barren & \\
\hline $49 \mathrm{R}-1,41-43$ & 386.81 & Barren & Barren & \\
\hline 50R-1, 7-11 & 391.17 & Barren & Barren & \\
\hline $52 \mathrm{R}-1,21-24$ & 397.51 & Barren & Barren & \\
\hline $53 \mathrm{R}-2,29-32$ & 404.59 & Dinocyst specimen & $\begin{array}{l}\text { Leiotriletes spp. } \\
\text { Buttinia andreevi }\end{array}$ & \\
\hline $54 \mathrm{R}-2,38-42$ & 414.98 & Barren & Barren & \\
\hline $55 \mathrm{R}-1,18-22$ & 417.98 & Barren & Barren & \\
\hline $56 \mathrm{R}-1,80-85$ & 423.60 & Barren & Barren & \\
\hline $58 \mathrm{R}-1,14-18$ & 432.54 & Barren & Barren & \\
\hline $59 \mathrm{R}-3,26-29$ & 440.02 & Barren & Brevicolporites sp. & \\
\hline $60 \mathrm{R}-2,73-76$ & 444.06 & Barren & Ephedripites sp. 1 & \\
\hline $61 \mathrm{R}-1,19-21$ & 446.39 & Barren & $\begin{array}{l}\text { Monosulcites spp. } \\
\text { Parvisaccites cf. P. radiatus } \\
\text { Trilete spore }\end{array}$ & \\
\hline
\end{tabular}

Note: The numbers in parentheses indicate the number of specimens counted for each species, whereas taxa without numbers indicate a single occurrence in the sample.

while the LO of T. castanea is in upper Campanian rocks (Williams et al., 1993). The lowermost documented occurrence of Cerodinium $s p$. is in Cenomanian rocks.

One specimen of the dinoflagellate cyst Cerodinium cf. C. leptodermum is present in Sample 159-962B-8H-6, 61-66 cm (72.61 mbsf). This dinoflagellate cyst also occurs at Site 959 and has its site base-stratigraphic range in Sample 159-959D-58R-1, 2-5 cm (956.82 mbsf), which is dated as late Campanian (see discussion for Site 959). Assuming that the FO of Cerodinium cf. C. leptodermum in Hole 959D corresponds to its lowermost occurrence in the stratigraphic record (regardless of preservation factors and/or condensation at that site), Sample 159-962B-8H-6, 61-66 cm (72.61 mbsf) is probably not older than late Campanian. The pollen Multiporopollenites sp. (Pl. 10, Fig. 26), which is present in this sample, occurs in upper Campanian rocks in the Book Cliffs, Utah, U.S.A. (ObohIkuenobe, unpubl. data). A Campanian to Maastrichtian age assignment is supported by the presence of the Late Cretaceous pollen Buttinia andreevi. Thus, palynological data can be used to bracket the age of Subunit IIC as late Albian to Maastrichtian. The interval from Core $159-962 \mathrm{~B}-11 \mathrm{H}$ through $13 \mathrm{H}$ is barren of calcareous nannofossils and planktonic foraminifers, although Core 159-962B-10H-CC (93 mbsf) was assigned a probable late Albian age on the basis of these microfossils (Shipboard Scientific Party, 1996e).

Two of seven samples from Hole 962D (Cores 159-962D-13R through 37R) yield single specimens of dinoflagellate cyst and acritarch taxa (Table 4). The dinoflagellate cysts reported in Samples 962D-24R-2, 41-45 cm (298.91 mbsf), and 962D-27R-1, 80-83 cm (312.10 mbsf), are not age diagnostic. On the contrary, stratigraphically important sporomorph taxa are present in this interval. The taxa include Triorites africaensis, Elaterosporites jardinei, Ephedripites multicostatus, Ephedripites spp., Circulina parva, Corollina jardi$n e i$, and $C$. torosus, which have been recovered in lower Albian to lower Cenomanian sediments in Senegal and Côte d'Ivoire (Jardiné and Magloire, 1965), lower Albian rocks in England (Kemp, 1970), Albian rocks in Maryland, U.S.A. (Brenner, 1963), and Albian to Cenomanian rocks in Brazil (Hengreen, 1972). The sporomorph data support the late Albian age assigned to this interval on the basis of calcareous nannofossils (Shipboard Scientific Party, 1996e).

\section{PALYNOFACIES ANALYSIS}

The dispersed organic matter in the sediments (Pl. 11, Figs. 1-12) are useful in deciphering the sources and depositional conditions of the drilled sequences. Several factors control the amount and types of dispersed organic matter in sedimentary rocks, and they include the sources of organic matter, depositional environment, lithology, tectonic setting, sea-level fluctuations, paleoclimate, paleoproductivity, sedimentation rate, diagenesis, and paleoceanography. In a marine setting, the narrow width of the continental shelf, such as the present shelf in the Côte d'Ivoire-Ghana Transform Margin (Mascle, Lohmann, Clift, et al., 1996), will exert an important control on the relative positions of proximal and distal facies of the different environments.

The palynofacies data presented in this study represent a subset of the Cretaceous to Pleistocene data discussed by Oboh-Ikuenobe et al. (1997). Qualitative analysis and R-mode cluster analysis indicate that the dominant palynodebris in most samples is AOM. A reduction in 

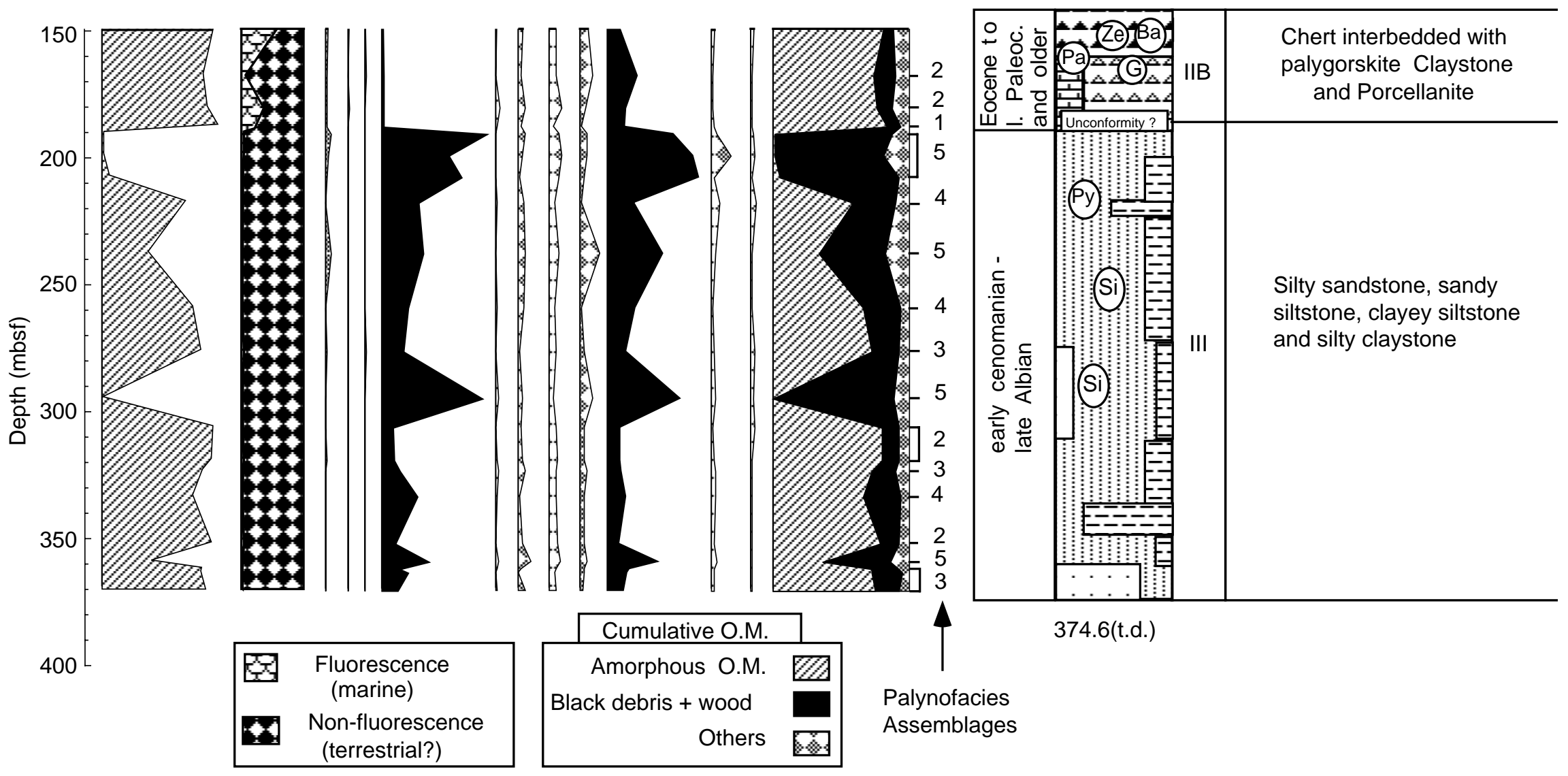

Figure 6. Percent distribution of dispersed organic matter at Site 961, including the fluorescence analysis of AOM, cumulative organic matter types derived from R-mode cluster analysis, sample positions of palynofacies assemblages, and lithofacies. In the lithofacies column, $\mathrm{Py}=$ pyrite; $\mathrm{Pa}=$ palygorskite claystone; $\mathrm{Ba}=$ barite nodule; $\mathrm{Ze}=\mathrm{zeolite} ; \mathrm{Si}=$ silica. The current water depth at this site is $3303 \mathrm{~m}$ (modified from Oboh-Ikuenobe et al., 1997). Age assignments and lithology for Subunit IIB and Unit III are based on Shipboard Scientific Party (1996d) and J. Mascle (pers. comm., 1996). 
Table 3. List of samples, sample depths, and palynomorphs identified in Holes 961A and 961B.

\begin{tabular}{|c|c|c|c|c|}
\hline $\begin{array}{l}\text { Core, section, } \\
\text { interval }(\mathrm{cm})\end{array}$ & $\begin{array}{l}\text { Depth } \\
\text { (mbsf) }\end{array}$ & $\begin{array}{c}\text { Dinoflagellate cysts } \\
\text { and acritarchs }\end{array}$ & Pollen and spores & Remarks \\
\hline \multicolumn{5}{|l|}{ 159-961A- } \\
\hline 19R-1, 35-38 & 167.75 & Barren & Barren & \\
\hline $20 \mathrm{R}-2,100-105$ & 179.50 & Barren & Barren & \\
\hline 21R-1, 63-68 & 187.33 & Barren & Barren & \\
\hline $21 \mathrm{R}-2,130-135$ & 189.50 & Barren & $\begin{array}{l}\text { Ephedripites spp. } \\
\text { Cyathidites minor }\end{array}$ & \\
\hline $22 \mathrm{R}-2,20-23$ & 198.10 & Barren & Cyathidites minor & Pediastrum sp. \\
\hline $23 \mathrm{R}-1,44-47$ & 206.54 & Barren & Barren & \\
\hline $24 \mathrm{R}-1,147-150$ & 217.17 & Barren & $\begin{array}{l}\text { Cyathidites minor } \\
\text { Ephedripites spp. }\end{array}$ & Pediastrum sp. \\
\hline $28 \mathrm{R}-3,20-22$ & 258.50 & Barren & Ephedripites spp. & \\
\hline $30 \mathrm{R}-1,66-68$ & 275.16 & Barren & Cyathidites minor & \\
\hline $32 \mathrm{R}-1,26-29$ & 294.06 & Barren & Ephedripites sp. 1 & \\
\hline $34 \mathrm{R}-2,32-37$ & 305.32 & Barren & $\begin{array}{l}\text { Ephedripites sp. } 2 \\
\text { Cyathidites minor }\end{array}$ & Pediastrum sp. \\
\hline \multirow{2}{*}{$\begin{array}{l}\text { 159-961B- } \\
11 \mathrm{R}-1,72-75\end{array}$} & & & & \\
\hline & 318.12 & Barren & $\begin{array}{l}\text { Cyathidites minor } \\
\text { Ephedripites spp. } \\
\text { Monosulcites } \mathrm{sp} .\end{array}$ & \\
\hline $12 \mathrm{R}-1,68-71$ & 323.08 & Barren & $\begin{array}{l}\text { Cyathidites minor } \\
\text { Ephedripites spp. }\end{array}$ & \\
\hline $13 \mathrm{R}-1,35-38$ & 332.45 & Barren & Retitriporites sp. & \\
\hline $15 \mathrm{R}-1,20-22$ & 351.60 & Barren & Barren & Pediastrum sp. \\
\hline $16 \mathrm{R}-3,30-33$ & 359.00 & Barren & $\begin{array}{l}\text { Cyathidites minor } \\
\text { Ephedripites spp. }\end{array}$ & \\
\hline $17 \mathrm{R}-1,24-28$ & 360.90 & Barren & Ephedripites spp. & \\
\hline $18 \mathrm{R}-1,48-51$ & 363.39 & Barren & $\begin{array}{l}\text { Cyathidites minor } \\
\text { Ephedripites spp. }\end{array}$ & \\
\hline 19R-CC, $1-3$ & 369.91 & Barren & & \\
\hline
\end{tabular}

Note: A single specimen was found for the listed taxa with the exception of Ephedripites spp. and Cyathidites minor.

AOM is often accompanied by an increase in terrestrially derived components such as wood and black debris. Q-mode cluster analysis of samples was used to identify palynofacies assemblages in the entire suite of sediments. The results, which are discussed in detail in Oboh-Ikuenobe et al. (1997), are summarized in Table 5. Figures 4 to 7 illustrate the distribution of palynodebris and cumulative patterns based on R-mode cluster analysis of Cretaceous to Paleocene sediments at the four sites. Five of the seven assemblages identified at Site 959 and one assemblage at Site 960 are illustrated and described in Plate 11, Figures 13 through 18. The amount of AOM in the sediments is the single most important factor that defines these assemblages. A paleobathymetric curve is also shown for Site 959 in Figure 4. This curve was reconstructed by integrating lithofacies, paleodepths of the CCD, trace fossils, benthic foraminifer, and tectonic setting with palynofacies data (see Oboh-Ikuenobe et al., 1997, for details and references).

Geochemical analysis using organic carbon vs. total nitrogen ratios $(\mathrm{C} / \mathrm{N})$ indicate that the organic components in the sediments were derived from both marine and terrestrial (dominant African) sources (Shipboard Scientific Party 1996b). This observation is confirmed by palynofacies analysis which shows that AOM is the dominant component in many samples. Fluctuations in TOC values and organic matter components show some correlation with lithology, although variations within lithologic units demonstrate changes in paleoenvironmental conditions and/or different stages of diagenetic overprint. Data obtained by Rock-Eval pyrolysis (Hydrogen Index and $\mathrm{T}_{\max }$ ) provide further information on the origin and stage of thermal maturity of organic matter in marine sediments (Espitalié et al., 1977; Tissot and Welte, 1984). Palynofacies data indicate that a high level of degradation has occurred at some intervals at all the sites. High values of nonfluorescing, more likely terrestrially derived AOM, are recorded, and the presence of poorly preserved spores, pollen, wood, and other fragments are documented for these intervals, such as lithologic Units III (black claystones) and Unit V (tectonized siliciclastic sediments) at Site 959 (Fig. 4). Hydrogen index values below 50 for Unit V suggest oxidation and biodegradation. Since this unit has the highest TAI value at this site, poor preservation may also be related to thermal maturation (see discussion below).
Terrestrially derived organic matter or AOM of terrestrial origin dominate the organic matter components of the siliciclastic sediments of the basal tectonized Unit V at Sites 959 and 960, and Unit III at Site 961 (Figs. 4-6). The absence of dinoflagellate cysts and microforaminiferal linings in these sediments is probably due to high degradation and/or dilution by high influx of sediment and landderived organic components (from Africa and possibly Brazil) into the basin. Based on the presence of varves in the siliciclastic sediments of Subunit VB at Site 960, these sediments have been interpreted as lacustrine (Shipboard Scientific Party, 1996c). The recovery of the highest percentages of cuticles and plant tissues in this subunit supports the above interpretation. Most of the organic matter components in these sediments have been degraded to nonfluorescing AOM. At Site 962, the basal Unit III contains interbedded hemipelagic siliciclastics and carbonate sediments (Fig. 7), and is rich in fluorescing AOM. Site 962 was deeper during the syntransform Albian stage with respect to the other three sites.

The general assumptions of palynofacies studies of passive margins (e.g., Oboh, 1992; Habib et al., 1994) indicate that a high concentration of terrestrially derived organic matter suggests proximity to the paleoshoreline, while a high concentration of marine-derived AOM is indicative of a distal location. In a transform margin setting, this assumption may not hold true in all cases because of tectonic processes. For example, the paleobathymetric curve for Site 959 (Fig. 4) shows that Unit IV, which is richer in marine AOM, is shallower than Unit V which is AOM poor (Palynofacies Assemblage 7 vs. Assemblages 1 and 2; Pl. 11, Figs. 13, 17). Lithologic evidence indicates that turbiditic processes have transported terrestrial organic matter into deep marine environments at some intervals, but in the absence of such lithologic evidence, we have related a high amount of such components to proximity to source.

The drastic increase in AOM and decrease in black debris and wood above lithologic Unit V at Sites 959 and 960 coincides with an unconformity between lithologic Units IV and V at these sites (Shipboard Scientific Party, 1996b; 1996c). The Upper Cretaceous to Paleocene black claystones of Unit III at Site 959 are absent at the other three sites. These sediments contain a high proportion of nonfluorescing, terrestrial AOM, and some input of wood, black debris, and 


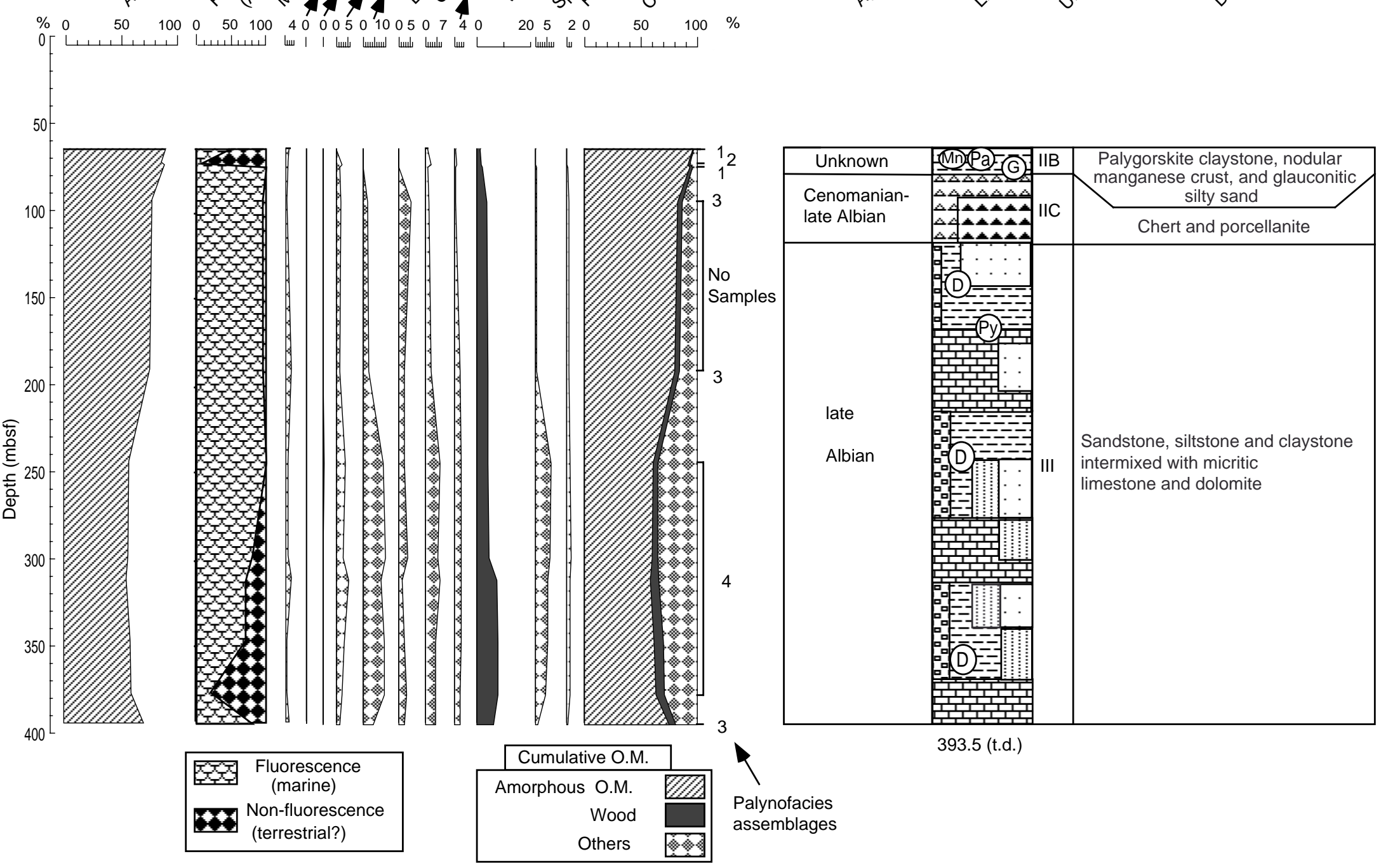

Figure 7. Percent distribution of dispersed organic matter at Site 962, including the fluorescence analysis of AOM, cumulative organic matter types derived from R-mode cluster analysis, sample positions of palynofacies assemblages, and lithofacies. In the lithofacies column, $\mathrm{Py}=$ pyrite; $\mathrm{G}=$ glauconite; $\mathrm{Pa}=$ palygorskite claystone; $\mathrm{Mn}=$ manganese nodule; $\mathrm{D}=$ dolomite. The current water depth at this site is $4662 \mathrm{~m}$ (modified from Oboh-Ikuenobe et al., 1997). Age assignments and lithology for Subunits IIB and IIC, and Unit III are based on Shipboard Scientific Party (1996e). 
Table 4. List of samples, sample depths, and palynomorphs identified in Holes 962B and 962D.

\begin{tabular}{|c|c|c|c|c|}
\hline $\begin{array}{l}\text { Core, section, } \\
\text { interval }(\mathrm{cm})\end{array}$ & $\begin{array}{l}\text { Depth } \\
\text { (mbsf) }\end{array}$ & $\begin{array}{l}\text { Dinoflagellate cysts } \\
\text { and acritarchs }\end{array}$ & $\begin{array}{l}\text { Pollen and } \\
\text { spores }\end{array}$ & Remarks \\
\hline \multicolumn{5}{|l|}{ 159-962B- } \\
\hline $8 \mathrm{H}-1,40-45$ & 64.90 & Spiniferites spp. & $\begin{array}{l}\text { Tricolpites sp. } 3 \\
\text { Tricolpopollenites spp. }\end{array}$ & Pediastrum sp. \\
\hline $8 H-6,61-66$ & 72.61 & $\begin{array}{l}\text { Leiosphaeridia "minor" } \\
\text { Cerodinium cf. C. leptoderma }\end{array}$ & Multiporopollenites sp. 1 & $\begin{array}{l}\text { Pediastrum } \mathrm{sp} . \\
\text { Not older than late Campanian }\end{array}$ \\
\hline $9 \mathrm{H}-1,69-73$ & 74.69 & $\begin{array}{l}\text { Cerodinium } \mathrm{sp} . \\
\text { Palaeohystrichophora infusorioides } \\
\text { Circulodinium distinctum } \\
\text { Trichodinium castaneum } \\
\text { Coronifera? } \text { cf. C. oceanica } \\
\text { Oligosphaeridium sp. } \\
\text { Exocosphaeridium } \mathrm{sp} . \\
\text { Spiniferites spp. } \\
\text { Areoligera } \mathrm{sp} . \\
\text { Cleistosphaeridium } \mathrm{sp} . \\
\text { Spinidinium } \mathrm{sp} . \\
\text { Leiosphaeridia } \mathrm{sp} . \\
\text { Pterospermella } \text { cf. P. ginginensis }\end{array}$ & $\begin{array}{l}\text { Tricolpites sp. } 3 \\
\text { Tricolpopollenites spp. } \\
\text { Tricolporopollenites } \mathrm{spp} . \\
\text { Classopollis torosus }\end{array}$ & Santonian-Campanian \\
\hline \multirow[t]{2}{*}{ 13X-CC, $3-5$} & 94.33 & Palaeohystrichophora infusorioides & Tricolpites sp. 3 & $\begin{array}{l}\text { Not older than late Albian-early } \\
\text { Cenomanian? }\end{array}$ \\
\hline & & $\begin{array}{l}\text { Spiniferites sp. } \\
\text { Spiniferites ramosus subsp. ramosus } \\
\text { Spiniferites cf. S. dentatus } \\
\text { Leiosphaeridia } \text { sp. }\end{array}$ & & \\
\hline \multicolumn{5}{|l|}{ 159-962D- } \\
\hline 13R-1, 23-25 & 191.23 & Barren & Tricolporopollenites spp. & late Albian \\
\hline 18R-4, 90-93 & 244.50 & Barren & & \\
\hline $24 \mathrm{R}-2,41-45$ & 298.91 & $\begin{array}{l}\text { Circulodinium distinctum } \\
\text { Exocosphaeridium? sp. } \\
\text { Spiniferites sp. }\end{array}$ & $\begin{array}{l}\text { Corollina torosus } \\
\text { Ephedripites sp. } 2 \\
\text { Circulina parva } \\
\text { Elaterosporites castelaini } \\
\text { Leiotriletes spp. } \\
\text { Triorites } \mathrm{cf} \text {. T. africaensis }\end{array}$ & late Albian \\
\hline $27 \mathrm{R}-1,80-83$ & 312.10 & $\begin{array}{l}\text { Exocosphaeridium bifidum } \\
\text { Cribroperidinium cf. C. auctificum } \\
\text { Pterospermopsis } \mathrm{sp} \text {. } \\
\text { Acritarch forma B }\end{array}$ & $\begin{array}{l}\text { Corollina jardinei } \\
\text { Striatopollis } \mathrm{sp} .\end{array}$ & late Albian \\
\hline $31 \mathrm{R}-2,89-92$ & 347.69 & Spiniferites ramosus & $\begin{array}{l}\text { Corollina jardinei } \\
\text { Buttinia? andreevi }\end{array}$ & late Albian \\
\hline $35 \mathrm{R}-2,140-144$ & 377.20 & Barren & Cyathidites minor & late Albian \\
\hline $37 \mathrm{R}-4,81-84$ & 393.81 & Barren & $\begin{array}{l}\text { Corollina torosus } \\
\text { Triorites africaensis }\end{array}$ & late Albian \\
\hline
\end{tabular}

black-brown fragments. This probably suggests an influx of terrestrial organic matter from Africa into the deep Ivorian Basin, and possibly from erosion of the marginal ridge to the south. However, there is no evidence to suggest that turbiditic processes transported these organic components into the deep basin. An increase in terrestrially derived organic matter, which is accompanied by relative abundances of Spiniferites spp. and Manumiella seelandica, in our uppermost Maastrichtian sample (159-959D-49R-4, 99-102 cm; $875.69 \mathrm{mbsf}$ ) at Site 959, is probably a reflection of the relative sea-level drop proposed just below the Cretaceous/Paleocene boundary (Haq et al., 1987).

\section{THERMAL MATURATION ANALYSIS}

Three major stages of thermal evolution have been documented for transform margins, namely intracontinental active transform with shear heating effect, continent-ocean active transform with friction and heat conduction, and passive transform margin with heat conduction (Todd and Keen, 1989; Mascle, Lohmann, Clift, et al., 1996). These thermal events are recorded by some of the sediments recovered at the Côte d'Ivoire-Ghana Transform Margin. By integrating TAI values for Cretaceous to Pleistocene sediments from Sites 959 to 962 with $_{\mathrm{m}_{\max }}$ data from Site 959 (Shipboard Scientific Party, 1996b) and clay mineral data (Shipboard Scientific Party, 1996a; Pletsch et al., 1996), Oboh-Ikuenobe et al. (1997) reconstructed the paleothermal history of the study area. Generally, TAI values lower than 2 correspond to vitrinite reflectance values $<0.4 \% \mathrm{VRo}$, and are indicative of an immature thermal stage (Robert, 1988). TAI values between 2 and 3 represent moderate maturity and correspond to the oil-window maturation, whereas values greater than 3 are considered mature to overmature. Some correlation exists between TAI and $\mathrm{T}_{\max }$ data at Site 959 (see Oboh-Ikuenobe et al., 1997). $\mathrm{T}_{\max }$ data indicate a persistent immature level for most samples (mainly those younger than the Campanian) close to the lower limit of the oil window ( $\mathrm{T}_{\max }$ scattering about $375^{\circ}-420^{\circ} \mathrm{C}$ ), although two samples from Unit III occur in the oil window, while Unit V samples are overmature $\left(465^{\circ}-485^{\circ} \mathrm{C}\right)$. A description of the thermal maturation analysis of the tectonic stages represented by Cretaceous to Paleocene sediments is given below.

\section{Intracontinental Transform Stage}

Clay mineral data for Sites 960 to 962 indicate that the basal tectonized siliciclastic units (i.e., Unit V at 959 and 960, and Unit III at 961 and 962) have been affected by high temperatures. The sediments are characterized by large amounts of chlorite and/or highly illitic mixed-layer clay minerals, but lack smectitic mixed-layer and other thermally unstable clay minerals. Moreover, mixed-layer clays are more ordered in the sediments of lithologic Unit III at Site 961 (R $=3$ vs. $\mathrm{R}=0$; Moore and Reynolds, 1989), and this is confirmed by higher TAI values recorded for the unit at this site. The values for the basal units at all the sites are typically greater than 2.5, but Site 961 records are the highest values. These observations indicate that either these sediments reached a higher temperature during burial at Site 961 than at Site 960, or that they were subjected to a high temperature for a longer period of time. The organic matter components in the three lowermost samples from Unit V at Site 959 were so dark that we could not identify any spore or pollen for measurement. These 
Table 5. Characteristics of palynofacies assemblages at Sites 959 through 962.

\begin{tabular}{|c|c|c|}
\hline Palynofacies & Units/subunits & Characteristics \\
\hline \multicolumn{3}{|l|}{ Site 959} \\
\hline 1 & V siliciclastics & $\begin{array}{l}\text { AOM }<15 \% \text {; black debris } 35 \%-39 \% \text {; wood } 37 \%-46 \% \text {; moderately high TAI } \\
\text { values }(2.6-3) \text {. }\end{array}$ \\
\hline 2 & V siliciclastics & AOM $2 \%$; black debris $65 \%$; wood $25.3 \%$; TAI values $>2.5$ \\
\hline 3 & IB nannofossil clay & $\begin{array}{l}\text { AOM } 30 \%-35 \% \text {; marine palynomorphs } 7 \%-15 \% \text {; cuticles } 6 \%-7 \% \text {; wood and } \\
\text { black brown fragments } 12 \%-17 \% \text { each. }\end{array}$ \\
\hline 4 & $\begin{array}{l}\text { IB, IIA, IV nannofossil chalk/clay, diatomite/clay, and sandy limestone, } \\
\text { respectively }\end{array}$ & AOM $43 \%-54 \% ;$ wood $9 \%-13.5 \%$ \\
\hline 5 & $\begin{array}{l}\text { IB, IIA, III nannofossil chalk/clay, diatomite/clay, and black claystone, } \\
\text { respectively }\end{array}$ & $\begin{array}{l}\text { AOM 55\%-65\%; black-brown fragments } 8 \%-12 \% \text {; fairly high TAI values (2-2.5) } \\
\text { in some Unit III claystones. }\end{array}$ \\
\hline 6 & $\begin{array}{l}\text { IIA, IIC, III diatomite/nannofossil clay, porcellanite, and black claystone } \\
\text { respectively }\end{array}$ & $\begin{array}{l}\text { AOM } 65 \%-78 \% \text {; black debris very rare; fairly high TAI values }(2-2.5) \text { in some } \\
\text { Unit III claystones. }\end{array}$ \\
\hline 7 & IIB, IIC, III chert/claystone porcellanite/clay, and black claystone, respectively & $\begin{array}{l}\text { AOM }>78 \% \text {; black debris very rare; fairly high TAI values }(2-2.5) \text { in some Unit } \\
\text { III claystones. }\end{array}$ \\
\hline \multicolumn{3}{|l|}{ Site 960} \\
\hline 1 & VA siliciclastics & AOM 7.5\%; dominated by wood fragments and black debris; TAI 2.5-2.9. \\
\hline 2 & VA, VB siliciclastics & AOM $62 \%-72 \%$; cuticle and wood $>7 \%$; TAI $2.5-2.9$. \\
\hline 3 & III palygorskite claystone & AOM $67 \%-75 \%$. \\
\hline 4 & III, IV, VB palygorskite claystone, limestone, and siliciclastics & $\begin{array}{l}\text { AOM } 73 \%-80 \% \text {; wood } 7 \%-15 \% \text {; much of the AOM in Subunit VB appears to be } \\
\text { terrestrially }\end{array}$ \\
\hline 5 & VA, VB Siliciclastics & $\begin{array}{l}\text { AOM } 81 \%-88 \% \text { mainly terrestrially derived; wood and black debris }<6 \% \text { each; } \\
\text { no marine palynomorphs were found; TAI }>2.5 \text {. }\end{array}$ \\
\hline \multicolumn{3}{|c|}{ 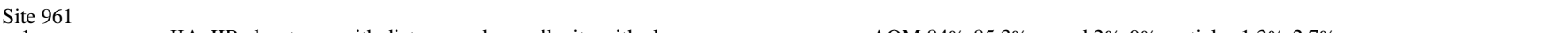 } \\
\hline 1 & IIA, IIB claystones with diatoms and porcellanite with clay & AOM 84\%-85.3\%; wood 2\%-9\%; cuticles $1.3 \%-2.7 \%$ \\
\hline 2 & IIB and III siliciclastics and nannofossil porcelanite & $\begin{array}{l}\text { AOM } 73 \%-80 \% \text {; probably terrestrially derived in Unit III samples; wood } 6 \% \text { - } \\
15.3 \% \text {; cuticles } 2.3 \%-4.7 \% \text {; black debris } 1.3 \%-7 \% \text {. }\end{array}$ \\
\hline 3 & III siliciclastics & AOM $72 \%-75 \% ;$ wood and black debris $7 \%-13 \%$ each; TAI generally $>3$. \\
\hline 4 & III siliciclastics & AOM $61 \%-66 \%$; wood and black debris $10 \%-19 \%$ each; TAI $2.8-3$ \\
\hline 5 & III siliciclastics & AOM $0 \%-36 \%$; wood and black debris $21 \%-53 \%$ each; TAI generally $>3$. \\
\hline \multicolumn{3}{|l|}{ Site 962} \\
\hline 1 & IIB, IIC palygorskite claystone and porcellanite & AOM $94 \%-96 \%$. \\
\hline 2 & IA, IIA, IIC clay, claystone, and porcellanite, respectively & AOM $86 \%-92 \%$ \\
\hline 3 & IA, IIC and III interbedded carbonates and siliciclastics & AOM $74 \%-83 \%$; wood and black debris $<11 \%$. \\
\hline 4 & III clayey dolomitic siltstone & $\begin{array}{l}\text { AOM 58\%-63\%; wood } 4.3 \%-8 \% \text {; black debris } 2.7 \%-5.7 \% \text {; cuticle } 4.3 \%-6.7 \% \text {; } \\
\text { yellow-brown } 8 \%-10 \% \text {; pollen/spores } 4.3 \%-6.7 \% \text {; TAI > } 2.5 \text {. }\end{array}$ \\
\hline
\end{tabular}

Notes: $\mathrm{AOM}=$ amorphous organic matter, TAI = thermal alteration index (modified from Oboh-Ikuenobe et al., 1997).

samples represent an overmature thermal stage. Apatite fission track data of Clift et al. (1995, 1996) suggest peak thermal temperatures $\left(>120^{\circ} \mathrm{C}\right)$ during the Albian. Therefore, the tectonized basal siliciclastic sediments record a thermal anomaly associated with the intracontinental to syntransform basin phase in the region.

\section{Continent-Ocean Transform Stage}

The uplift of the marginal ridge began during the continent-ocean transform stage (latest Albian?/Cenomanian to Turonian) because of the proximity of the hot oceanic lithosphere to the nearby continental margin, and the passage of the oceanic spreading center south of the transform margin (Shipboard Scientific Party, 1996a). Reef deposits at Sites 959 and 960 (Unit IV) mark the maximum uplift of the ridge during the Turonian to early Coniacian. There is no TAI record of any thermal anomaly associated with the spreading center because this event is marked by an unconformity below the reef sediments at the four sites. With the exception of one carbonate sample at Site 959, and one porcellanite sample at Site 962, the reef and other deposits representing this stage of evolution are thermally immature (with TAI values lower than 2).

\section{Passive Transform Stage}

The passive transform margin phase began during the late Coniacian and has continued until the present time. At Site 959, TAI values indicate moderate maturity for black claystones (basal Unit III) of late Coniacian to Campanian age. The presence of phosphatic hardgrounds at this site (Core 159-959D-66R) and at Site 960 (Core 159960C-23X) is indicative of very low sedimentation rates and hiatuses during the late Coniacian to late Santonian, which probably affected the organic matter in the sediments. Clay minerals also indicate a change from illite-bearing assemblages (Coniacian to Santonian) to assemblages that are almost exclusively composed of smectite and minor kaolinite (Campanian to Maastrichtian; Pletsch et al., 1996).

A thermal anomaly of Santonian to Campanian age, which accompanied heavy subsidence, has been reported in the northwestern section of the neighboring Benue Trough and in the Anambra Basin in Nigeria (Allix et al., 1984; Robert, 1988). Although the Benue Trough and the Côte d'Ivoire-Ghana Transform Margin are both linked to the fossil Romanche Fracture Zone, their structural settings are different. We do not have any evidence to link the moderate maturity of the organic matter in our samples to the same thermal anomaly in the Benue Trough and Anambra Basin.

\section{CONCLUSIONS}

Biostratigraphic interpretations of the Upper Cretaceous to Paleocene sediments at Sites 959 to 962 were based largely on the occurrences of dinoflagellate cysts, and to a lesser extent on spores and pollen. Ages were assigned to samples whenever possible, and a summary is given below.

159-959D-67R-1, 10-14 cm, and 68R-1, 16-19 cm, Turonian to early Coniacian.

159-959D-62R-1, 21-24 cm, through 65R-6, 10-13 cm, Santonian.

159-959D-60R-4, 94-96 cm, and 60R-2, 100-104 cm, early Campanian. 
159-959D-58R-1, 2-5 cm, and 59R-2, 45-50 cm, late Campanian.

159-959D-55R-3, 85-88 cm, through 56R-2, 80-82 cm, early Maastrichtian

159-959D-54R-1, 37-39 cm, latest early Maastrichtian to earliest late Maastrichtian.

159-959D-49R-4, 99-102 cm, through 53R-4, 67-70 cm, late Maastrichtian.

159-959D-48R-5, 37-41 cm, Danian.

159-959D-47R-1, 66-69 cm, and 46R-1, 7-12 cm, not older than latest Danian.

The presence of the dinoflagellate cysts Kenleyia spp. in sample 159-959D-49R-4, 99-102 cm (875.69 mbsf), may indicate a condensed Maastrichtian/Danian boundary in this sample. This hypothesis can be proved by analyzing additional samples and specimens of Kenleyia spp.

159-960A-21R-1, 43-48 cm, not younger than early Maastrichtian but not older than Santonian.

159-962B-8H-6, 61-66 cm, not older than late Campanian

159-962B-9H-1, 69-73 cm, Santonian to Campanian.

159-962B-13X-CC, 3-5 cm, not older than late Albian to early Cenomanian?

159-962D-13R-1, 23-23 cm, through 37R-4, 81-84 cm, late Albian

Palynofacies analysis has been used in the reconstruction of the sedimentary environments represented and the clarification of the origin of dispersed organic matter in the sediments. The organic matter is predominantly of marine origin (composed primarily of AOM), and a decrease in AOM is often accompanied by an increase in terrestrially derived organic matter (mostly wood and black debris). At Sites 959 and 960, carbonate and clastic rocks of lithologic Unit IV above the post-Albian unconformity are much richer in AOM and poorer in terrestrial organic matter with respect to the underlying tectonized rocks of lithologic Unit V. The high concentration of black debris and wood just below the unconformity surface may be due to degradation of organic matter during long exposure, oxygenation, and probably erosion of the depositional surface. The higher amounts of terrestrially derived organic matter in the Unit V are related to high input from Africa and possibly Brazil during the syntransform phase. An increase in terrestrial organic matter in the Cretaceous/Paleocene boundary at Site 959 may be related to a drop in sea level.

The organic matter in several of the samples analyzed is thermally immature. TAI values greater than 2.0, which indicate moderate thermal maturity, occur in some black claystones and limestone at Site 959 (Units III and IV), and in the tectonized basal siliciclastic sediments at all the sites (Unit V at Sites 959 and 960, and Unit III at Sites 961 and 962). They correlate well with Rock-Eval pyrolysis and clay mineral data. The tectonized basal siliciclastic sediments typically have values greater than 2.5, with the highest values (up to 3.13 ) occurring at Site 961. These sediments at Site 961 either reached a higher temperature during burial, or they were subjected to a high temperature for a longer period of time. The thermal event in the basal sediments is related to the syntransform phase of the basin.

\section{SYSTEMATICS}

Division DINOFLAGELLATA (Bütschli 1885) Fensome et al., 1993 Subdivision DINOKARYOTA Fensome et al., 1993 Class DINOPHYCEAE Pascher, 1914 Subclass PERIDINIPHYCIDAE Fensome et al., 1993 Order GONYAULACALES Taylor, 1980

Kenleyia sp. A

(Pl. 7, Figs. 4-7)
Description: Cyst proximochorate, body spherical to subspherical with a microreticulate autophragm. One apical and one or two antapical hornlike projections up to $10 \mu \mathrm{m}$ long, with blunt tips. An external and discontinuous layer is discernible forming variable projections of short fibrous processes, and discontinuous lace-like lamellar structures. In two of the four specimens analyzed, the processes are slightly more prominent at each side of the paracingulum. Specimen illustrated in Plate 7, Figure 4, shows a microreticulate autophragm, bearing few nontabular spines and thin, longer fibrous processes $(9 \mu \mathrm{m})$ that have an apparent alignment parallel to the expected location of the paracingulum, which is not clearly expressed. Spine length varies from 2-3 $\mu \mathrm{m}$. Antapical horn has a hair-like projection on its tip and three more on one of its margins. Paracingulum faintly evident. Archeopyle precingular, prominent, isomegaform (Pl. 7, Fig. 5) or eurymegaform (Pl. 7, Fig. 7).

Dimensions: Total length $76.8-83.2 \mu \mathrm{m}$, breadth $60.8-75.2 \mu \mathrm{m}$, length of apical and antapical horns $8-12.8 \mu \mathrm{m}$. Number of specimens measured: 4 .

Comparison: These specimens differ from Kenleyia pachycerata in the absence of two smaller projections on each side of the apical and antapical horns, and in having short and discontinuous ornamentation. Kenleyia leptocerata has accessory apical outgrowths, which are absent in these specimens. The specimens differ from Fibrocysta in having low, poorly delimited fibrous projections or lamellar lace-like structures, rather than more or less distinct and generally long processes.

Occurrence: Sample 159-959D-49R-4, 99-102 cm (875.69 mbsf).

\section{Kenleyia cf. K. lophophora, Cookson and Eisenack, 1965 (Pl. 7, Figs. 8 and 9)}

Description: Cyst proximochorate, body subspherical to ellipsoidal with one apical and one antapical horn-like projections. Autophragm microreticulate, bearing low tuft-like processes or fibrous lamellar structures of variable width. Some of the processes end with short spines or hair-like projections. The tuft-like processes are slightly better developed on either side of the api$\mathrm{cal}$ and antapical horns and on the lateral limits of the paracingulum. The apical horn has a blunt tip and has spines along its margins. Paracingulum indicated by two closely spaced, low, transverse ridges. Archeopyle precingular and large.

Dimensions: Length $99.2 \mu \mathrm{m}$, breadth $75.2 \mu \mathrm{m}$, length of apical and antapical horn $19.2 \mu \mathrm{m}$, height of processes 3-7 $\mu \mathrm{m}$, width of processes 5-20 $\mu \mathrm{m}$. Number of specimens measured: 1 .

Comparison: This specimen differs from Kenleyia lophophora in having an apical horn with spines in its margin and in having less-developed tuft-like projections.

Occurrence: Sample 159-959D-49R-4, 99-102 cm (875.69 mbsf).

\section{ACKNOWLEDGMENTS}

This research was supported by a USSAC Grant to the senior author. Discussions with Peter Clift, Wolfgang Kuhnt, Thomas Pletsch, Javier Helenes, Sarah Damassa, Henk Brinkhuis, and David Pocknall are greatly appreciated. This manuscript benefited greatly from reviews by R. Farley Fleming and Javier Helenes.

\section{REFERENCES}

Allix, P., Legoux, O., and Robert, P., 1984. Essai d'interprétation géodynamique de l'evolution mésozoïque de sous-bassins du Fossé de la Bénoué (Nigéria). Bull. Soc. Geol. Fr., 7:1061-1068.

Below, R., 1981. Dinoflagellaten-Zysten aus dem oberen Hauterive bisunteren Cenoman Südwest-Marokkos. Palaeontographica B, 176:1-145.

, 1984. Aptian to Cenomanian dinoflagellate cysts from the Mazagan Plateau, northwest Africa (Sites 545 and 547, DSDP Leg 79). In Hinz, K., Winterer, E.L., et al., Init. Repts. DSDP, 79: Washington (U.S. Govt. Printing Office), 621-649.

Benson, D.G., 1976. Dinoflagellate taxonomy and stratigraphy at the Cretaceous-Tertiary boundary, Round Bay, Maryland. Tulane Stud. Geol. Paleontol., 12:169-233.

Brenner, G.J., 1963. The Spores and Pollen of the Potomac Group of Maryland. Maryland Dept. Geol., Min. Water Res. Bull., 27.

Brinkhuis, H., and Leereveld, H., 1988. Dinoflagellate cysts from the Cretaceous/Tertiary boundary sequence of El Kef, northwest Tunisia. Rev. Palaeobot. Palynol., 6:5-19. 
Clarke, R.F.A., and Verdier, J.P., 1967. An investigation of microplankton assemblages from the Chalk of the Isle of Wight, England. Verh. K. Nederl. Akad. Wetensch., 24:1-96.

Clift, P.D., Allerton, S., Bouillin, J.P., and ODP Leg 159 Shipboard Scientific Party, 1996. Formation of the Côte d'Ivoire-Ghana Marginal Ridge: transform tectonics versus thermal rejuvenation. Geol. Soc. London Meeting. (Abstract)

Clift, P.D., Bouillin, J.P., Hurford, A.J., and ODP Leg 159 Shipboard Scientific Party, 1995. Apatite fission track dating of sediments from the Ghana-Côte d'Ivoire Transform Margin. Am. Geophys. Union, Ann. Meeting. (Abstract)

de Coninck, J., and Smit, J., 1982. Marine organic-walled microfossils at the Cretaceous-Tertiary boundary in the Barranco del Gredero (S.E. Spain). Geol. Mijnbouw, 61:173-178.

Espitalié, J., Laporte, J.L., Leplat, P., Madec, M., Marquis, F., Paulet, J., and Boutefeu, A., 1977. Méthode rapide de caractérisation des roches mères, de leur potentiel pétrolier et de leur degré d'évolution. Rev. Inst. Fr. Pet., 32:23-42.

Faegri, K., and Iversen, J., 1989. Textbook of Pollen Analysis (4th ed.): Chichester (Wiley).

Fail, J.P., Montadert, L., Delteil, J.R., Valery, P., Patriat, P., and Schlich, R., 1970. Prolongation des zones de fractures de l'océan Atlantique dans le golfe de Guinée. Earth Planet. Sci. Lett., 7:413-419.

Fensome, R.A., Taylor, F.J.R., Norris, G., Sarjeant, W.A.S., Wharthom, D.I., and Williams, G.L., 1993. A classification of living and fossil dinoflagellates. Micropaleontol., Spec. Publ. 7.

Firth, J.V., 1987. Dinoflagellate biostratigraphy of the Maastrichtian to Danian interval in the U. S. Geological Survey Albany core, Georgia, U.S.A. Palynology, 11:199-216.

, 1993. Dinoflagellate assemblages and sea-level fluctuations in the Maastrichtian of southwest Georgia. Rev. Palaeobot. Palynol., 79:179204

Germeraad, J.H., Hopping, C.A., and Müller, J., 1968. Palynology of Tertiary sediments from tropical areas. Rev. Palaeobot. Palynol., 6:189-348.

Habib, D., Eshet, Y., and Van Pelt, R., 1994. Palynology of sedimentary cycles. In Traverse, A. (Ed.), Sedimentation of Organic Particles: Cambridge (Cambridge Univ. Press), 311-335.

Habib, D., and Miller, J.A., 1989. Dinoflagellate species and organic facies evidence of marine transgression and regression in the Atlantic Coastal Plain. Palaeogeogr., Palaeoclimatol., Palaeoecol., 74:23-47.

Hansen, J.M., 1977. Dinoflagellate stratigraphy and echinoid distribution in Upper Maastrichtian and Danian deposits from Denmark. Bull. Geol. Soc. Den., 26:1-26.

Haq, B.U., Hardenbol, J., and Vail, P.R., 1987. Chronology of fluctuating sea levels since the Triassic. Science, 235:1156-1167.

Helby, R., Morgan, R., and Partridge, A.D., 1987. A palynological zonation of the Australian Mesozoic. In Jell, P.A. (Ed.), Studies in Australian Mesozoic Palynology. Mem. Assoc. Australas. Palaeontol., 4:1-94.

Helenes, J., 1984. Dinoflagellates from Cretaceous to Early Tertiary rocks of the Sebastian Vizcaino Basin, Baja California, Mexico. In Frizzell, V.A., Jr. (Ed.), Geology of the Baja California Peninsula. Soc. Econ. Paleontol. Mineral., Pacific Sect., 39:89-106.

Hengreen, G.F.W., 1972. Palynology of Albian-Cenomanian strata of Borehole 1-QS-1-MA, State of Maranhao, Brazil. Pollen Spores, 15:515-555.

Hultberg, S.U., 1985. Dinoflagellate studies of the Upper Maastrichtian and Danian in southern Scandinavia [thesis]. Univ. of Stockholm.

, 1986. Danian dinoflagellate zonation, the C-T boundary and the stratigraphical position of the Fish Clay in southern Scandinavia. J.Micropalaeontol., 5:37-47.

Hultberg, S.U. and Malmgren, B.A., 1987. Quantitative biostratigraphy based on late Maastrichtian dinoflagellates and planktonic foraminifera from southern Scandinavia. Cret. Res., 8:211-228.

Hultberg, S.U. and Malmgren, B.A., 1985. Quantitative biostratigraphy based on Upper Maastrichtian dinoflagellates and planktonic foraminifera from southern Scandinavia. In Hultberg, S.U. (Ed.), Dinoflagellate Studies of the Upper Maastrichtian and Danian in southern Scandinavia. Dept. of Geol., Univ. of Stockholm, 33-35.

Jain, K.P., and Millepied, P., 1973. Cretaceous microplankton from Senegal Basin, West Africa, Part I: Some new genera, species and combinations of dinoflagellates. Palaeobotanist, 20:22-32.

Jaramillo, C., and Yepes, O., 1994. Palinoestratigrafia del Grupo Olini (Coniaciano-Campaniano), Valle Superior del Magdalena, Colombia. In EtayoSerna, F. (Ed.), Estudios Geologicos del Valle Superior del Magdalena.
Univ. Nacional de Colombia-Empresa Colombiana de Petróleos, XVII-1XVII-18.

Jaramillo, C.A., 1995. Dinoflagellate cyst biostratigraphy and palynofacies of the Late Eocene-Early Oligocene in Southern Mississippi and Alabama, U.S. Gulf Coast [M.S. thesis]. Univ. of Missouri-Rolla.

Jardiné, S., and Magloire, L., 1965. Palynologie et stratigraphie du Crétacé des bassins du Sénégal et du Côte d'Ivoire. Mem. Bur. Rech. Geol. Minieres, 32:187-245.

Kemp, E.M., 1970. Aptian and Albian miospores from southern England. Palaeontographica B, 131:73-143.

Kirsch, K.H., 1991. Dinoflagellaten-Zysten aus der Oberkreide des Helvetikums und Nordultrahelvetikums von Oberbayern. Münchner Geowiss. Abh., Reihe A, Geol. Palaeontol., 22:1-306.

Kjellström, G., 1973. Maastrichtian microplankton from the Höllviken Borehole no.1 in Scania, southern Sweden. Sver. Geol. Undersökning, Afhandl. Uppsat., 67:1-59.

Koch, R., and Olsson, R.K., 1977. Dinoflagellate and Planktonic foraminiferal biostratigraphy of the uppermost Cretaceous of New Jersey. $J$. Paleontol., 51:480-491.

Kotova, I.Z., 1978. Spores and pollen from Cretaceous deposits of the eastern North Atlantic Ocean, Deep Sea Drilling Project, Leg 41, Sites 367 and 370. In Perch-Nielsen, K., Supko, P.R., et al., Init. Repts. DSDP, 41 (Pt. 2): Washington (U.S. Govt. Printing Office), 841-881.

Kuhnt, W., Kaminski, M.A., Holbourn, A., DeKlasz, S., Moullade, M., Pletsch, T., and ODP Leg 159 Shipboard Scientific Party, 1996. Cretaceous benthic foraminifera from the Guinea Margin (Leg 159) and the paleoceanography of the Equatorial Atlantic Gateway: preliminary results. European ODP Meeting. (abstract)

Lorente, M.A., 1990. Textural characteristics of organic matter in several subenvironments of the Orinoco upper deltaic plain. Geol. Mijnbouw, 69:263-278.

Marheinecke, U., 1992. Monographie der Dinozysten, Acritarcha und Chlorophyta des Maastrichtium von Hemmoor (Niedersachsen). Palaeontographica $B, 227: 1-173$.

Mascle, J., Lohmann, G.P., Clift, P.D., and Shipboard Scientific Party, 1996. Introduction. In Mascle, J., Lohmann, G.P., Clift, P.D., et al., Proc. ODP, Init. Repts., 159: College Station, TX (Ocean Drilling Program), 5-16.

Moore, D.M., and Reynolds, R.C., Jr., 1989. X-ray Diffraction and the Identification and Analysis of Clay Minerals: Oxford (Oxford Univ. Press).

Oboh, F.E., 1992. Multivariate statistical analyses of palynodebris from the Middle Miocene of the Niger delta and their environmental significance. Palaios, 7:559-573.

Oboh-Ikuenobe, F.E., Yepes, O., and ODP Leg 159 Scientific Party, 1997. Palynofacies analysis of sediments from the Côte d'Ivoire-Ghana Transform Margin: preliminary correlation with some regional events in the Equatorial Atlantic. Palaeogeogr, Palaeoclimatol., Palaeoecol., 129:291. 314

Pletsch, T., Erbacher, J., Kuhnt, W., and ODP Leg 159 Shipboard Scientific Party, 1996. Clay minerals of Cretaceous and Paleogene deposits from the eastern Equatorial Atlantic: preliminary results from ODP Leg 159 (Côte d'Ivoire-Ghana Transform Margin). European ODP Meeting. (abstract)

Rauscher, R., and Doubinger, J., 1982. Les dinokystes du Maestrichtien phosphaté au Maroc. Sci. Geol., 35:97-116.

Robert, P., 1988. Organic Metamorphism and Geothermal History: Dordrecht (D. Reidel).

Salami, M.B., 1990. Palynomorph taxa from the "Lower Coal Measures" deposits (?Campanian-Maastrichtian) of Anambra Trough, southeastern Nigeria. J. Afr. Earth Sci., 11:135-150.

Shipboard Scientific Party, 1996a. Principal results. In Mascle, J., Lohmann, G.P., Clift, P.D., et al., Proc. ODP, Init. Repts., 159: College Station, TX (Ocean Drilling Program), 297-314.

1996b. Site 959. In Mascle, J., Lohmann, G.P., Clift, P.D., et al., Proc. ODP, Init. Repts., 159: College Station, TX (Ocean Drilling Program), 65-150.

, 1996c. Site 960. In Mascle, J., Lohmann, G.P., Clift, P.D., et al., Proc. ODP, Init. Repts., 159: College Station, TX (Ocean Drilling Program), 151-215.

1996d. Site 961. In Mascle, J., Lohmann, G.P., Clift, P.D., et al., Proc. ODP, Init. Repts., 159: College Station, TX (Ocean Drilling Program), 217-249.

, 1996e. Site 962. In Mascle, J., Lohmann, G.P., Clift, P.D., et al., Proc. ODP, Init. Repts., 159: College Station, TX (Ocean Drilling Program), 251-294. 
Soncini, M.J., and Rauscher, R., 1988. Associations de Dinokystes du Maastrichtien-Paléocène phosphaté au Maroc. Bull. Cent. Rech. Expl.-Prod. Elf-Aquitaine, 12:427-450.

SYSTAT 5 for the Macintosh, 1990-92, Version 5.2.1. Copyright, SYSTAT Inc., 603 Main Street, Evanston, Illinois 60202, U.S.A.

Tissot, B.P., and Welte, D.H., 1984. Petroleum Formation and Occurrence (2nd ed.): Heidelberg (Springer-Verlag).

Todd, B.J., and Keen, C.E., 1989. Temperature effects and their geological consequences at transform margins. Can. J. Earth Sci., 26:2591-2603.

Uwins, P.J.R., and Batten, D.J., 1988. Early to mid-Cretaceous palynology of northeast Libya. In El-Arnauti, A., et al. (Eds.), Subsurface Palynostratigraphy of Northeast Libya: 215-257.

van Hoeken-Klinkenberg, P.M.J., 1964. Maastrichtian, Paleocene and Eocene pollen and spores from Nigeria. Leidse Geol. Meded., 38:378.

Williams, G.L., and Bujak, J.P., 1985. Mesozoic and Cenozoic dinoflagellates. In Bolli, H.M, Saunders, J.B., and Perch-Nielsen, K. (Eds.), Plankton Stratigraphy: Cambridge (Cambridge Univ. Press), 847-964.

Williams, G.L., Stover, L.E., and Kidson, E.J., 1993. Morphology and Stratigraphic Ranges of Selected Mesozoic-Cenozoic Dinoflagellate Taxa in the Northern Hemisphere. Pap.-Geol. Surv. Can., 92-10.

Wilson, G.J., 1974. Upper Campanian and Maastrichtian dinoflagellate cysts from the Maastricht region and Denmark [Ph.D. dissert.]. Nottingham Univ.

1978. The dinoflagellate species Isabelia druggii (Stover) and Isabelia seelandica (Lange): their association in the Teurian of Woodside Creek, Marlborough, New Zealand. N. Z. J. Geol. Geophys., 21:75-80.

\section{Date of initial receipt: 16 October 1996 \\ Date of acceptance: 18 March 1997 \\ Ms 159SR-016}

\section{APPENDIX A}

Alphabetical list of phytoplankton species identified in this study. All the references cited can be found in Lentin and Williams (1993).

Achomosphaera cf. A. danica (W. Wetzel, 1952) Sarjeant, 1984

Achomosphaera mariannae (Philipott, 1949) Stover and Evitt, 1978

Achomosphaera ramulifera (Deflandre, 1937) Evitt, 1963

Achomosphaera? ramulifera subsp. gabonensis (Boltenhagen, 1977) Lentin and Williams, 1981

Achomosphaera ramulifera subsp. ramulifera (Deflandre, 1937b) Evitt, 1963

Achomosphaera sagena Davey and Williams, 1966a

Achomosphaera sp. A

Acritarch Forma A

Acritarch Forma B

Alterbidinium? sp.

Alterbidinium varium Kirsch, 1991

Alysogymnium euclaense (Cookson and Eisenak, 1970a) Lentin and Vozzhennikova, 1990

Andalusiella gabonense Stover and Evitt, 1978

Andalusiella sp.

Apteodinium sp.

Areoligera cf. A. senonensis Lejeune-Carpentier, 1938

Areoligera coronata (O. Wetzel, 1933b) Lejeune-Carpentier, 1938

Areoligera lemniscata Stover and Evitt, 1978

Areoligera senonensis Lejeune-Carpentier, 1938

Areoligera sp. A

Areoligera spp.

Batiacasphaera sp.

Canningia senonica Clarke and Verdier, 1967

Canningia sp.

Cerodinium boloniense (Riegel, 1974b) Lentin and Williams, 1989

Cerodinium cf. C. leptodermum (Vozzhennikova, 1963) Lentin and Williams, 1987

Cerodinium diebelii (Alberti, 1959b) Lentin and Williams, 1987

Cerodinium granulostriatum (Jain and Millepied, 1973) Lentin and Williams, 1987

Cerodinium leptodermum (Vozzhennikova, 1963) Lentin and Williams, 1987

Cerodinium spp.

Cerodinium sp. A

Cerodinium speciosum (Alberti, 1959b) Lentin and Williams, 1987

Cerodinium striatum (Drugg, 1967) Lentin and Williams, 1987
"Chytroeisphaeridia everricula" of Wilson, 1974

Chytroeisphaeridia spp.

Circulodinium distinctum (Deflandre and Cookson, 1955) Jansonius, 1986

Circulodinium sp.

Circulodinium sp. A

Cleistosphaeridium cf. C. clavulum (Davey 1969) Below, 1982c

Cleistosphaeridium spp.

Cleistosphaeridium flexuosum Davey et al., 1966b

Cometodinium sp. cf. C.? whitei (Deflandre and Courteville, 1939) Stover and Evitt, 1978

Cordosphaeridium fibrospinosum Davey and Williams, 1966b

Cordosphaeridium exilimurum Davey and Williams, 1966b

Cordosphaeridium inodes (Klumpp, 1953) Eisenack, 1963b emend. Morgenroth, 1968

Cordosphaeridium spp.

Cordosphaeridium sp.

Coronifera oceanica Cookson and Eisenack, 1958 emend. May, 1980

Cribroperidinium cf. C. auctificum (Brideaux, 1971) Stover and Evitt, 1978

Cribroperidinium wetzelii (Lejeune-Carpentier, 1939) Helenes, 1984b

Cyclapophysis monmouthensis

Cyclonephelium? castelcasiense Corradini, 1973

Cyclonephelium cf. C. crassimarginatum Cookson and Eisenack, 1974

Cyclonephelium compactum Deflandre and Cookson, 1955

Cyclonephelium crassimarginatum Cookson and Eisenack, 1974

Cyclonephelium sp. A

Cyclonephelium paucispinum Davey 1969a

Cyclonephelium vannophorum Davey, 1969a

Dinogymnium acuminatum Evitt et. al., 1967

Dinogymnium cretaceum (Deflandre, 1935) Evitt et al., 1967

Dinogymnium longicorne (Vozzhennikova, 1967) Harland, 1973a

Dinogymnium sp.

Dinogymnium undulosum Cookson and Eisenack, 1970a

Dinogymnium westralium (Cookson and Eisenack, 1958) Evitt, Clarke and Verdier, 1967 emend. May, 1977

Diphyes cf. D. colligerum (Deflandre and Cookson, 1955) Cookson, 1965a emend. Goodman and Witmer, 1985

Diphyes colligerum (Deflandre and Cookson, 1955) Cookson, 1965a emend Goodman and Witmer, 1985

Exochosphaeridium bifidum (Clarke and Verdier, 1967) Clarke et al., 1968

Exochosphaeridium phragmites Davey et al., 1966b

Exocosphaeridium sp. A

Exocosphaeridium sp. B

Exophosphaeridium spp.

Fibrocysta bipolaris (Cookson and Eisenack, 1965b) Stover and Evitt, 1978

Fibrocysta cf. F. klumppiae (Corradini, 1973) Stover and Evitt, 1978

Fibrocysta sp. A

Fibrocysta spp.

Fibrocysta cf. F. bipolaris (Cookson and Eisenack, 1965b) Stover and Evitt, 1978

Fibrocysta vectensis (Eaton, 1976) Stover and Evitt, 1978

Florentinia cooksoniae (C. Singh, 1971) Duxbury, 1980

Florentinia ferox (Deflandre, 1937b) Duxbury, 1980

Geiselodinium psilatum Jain and Millepied, 1973

Glaphyrocysta cf. G.divaricata (Williams and Downie, 1966c) Stover and Evitt, 1978

Glaphyrocysta divaricata (Williams and Downie, 1966c) Stover and Evitt, 1978

Glaphyrocysta exuberans (Deflandre and Cookson, 1955) Stover and Evitt, 1978

Glaphyrocysta ordinata (Williams and Downie, 1966c) Stover and Evitt, 1978

Glaphyrocysta perforata Hultberg and Malmgren, 1985.

Glaphyrocysta sp. B

Granodiscus granulatus

Hystrichodinium pulchrum Deflandre, 1935

Hystrichosphaeridium cf. H. tubiferum (Ehrenberg, 1838) Deflandre, 1937b emend. Davey and Williams, 1966b

Hystrichosphaeridium sp.

Hystrichosphaeridium tubiferum (Ehrenberg, 1838) Deflandre, 1937b emend. Davey and Williams, 1966b

Isabelidinium cooksoniae (Alberti, 1959b) Lentin and Williams, 1977a

Kallosphaeridium? sp.

Kallosphaeridium? ringnesiorum (Manum and Cookson, 1964) Helby, 1987b

Kenleyia leptocerata Cookson and Eisenack, 1965b. 
Kenleyia cf. K. lophophora Cookson and Eisenack, 1965b.

Kenleyia sp. A.

Lejeunecysta sp.

Leiosphoeridia sp. A

Leiosphaeridia sp. B

Manumiella raijae (Kjellström, 1973) Bujak and Davies, 1983

Manumiella seelandica (Lange, 1969) Bujak and Davies, 1983 emend. Firth, 1987

Membranilarnacia? sp.

Micrhystridium sp.

Micrhystridium sp. cf. M. castaneoideum Stockmans and Willière, 1969

Odontochitina operculata (O. Wetzel, 1933a) Deflandre and Cookson, 1955

Odontochitina porifera Cookson, 1956

Odontochitina spp.

Oligosphaeridium complex (White, 1842) Davey and Williams, 1966b

Palaeocystodinium australinum (Cookson, 1965b) Lentin and Williams, 1976

Palaeocystodinium benjaminii Drugg, 1967

Palaeocystodinium lidiae (Gorka, 1963) Davey, 1969b

Palaeocystodinium sp.A of Bujak and Davies, 1983

Palaeocystodinium sp. B

Palaeocystodinium sp. C

Palaeocystodinium cf. P. golzowense Alberti, 1961

Palaeocystodinium spp.

Palaeohystrichophora infusorioides Deflandre, 1935

Palaeoperidinium cf. P. pyrophorum (Ehrenberg, 1838) Sarjeant, 1967b

Palaeoperidinium cretaceum Pocock, 1962a

Palambages spp.

Palambages morulosa Wetzel, 1991

Phelodinium gaditanum (Riegel, 1974b) Lentin and Williams, 1981 emend. Riegel and Sarjeant, 1982

Phelodinium sp.

Pierceites pentagona (May, 1980) Habib and Drugg, 1987

Pterospermopsis australiensis Deflandre and Cookson, 1954

Pterospermopsis ginginensis Deflandre and Cookson, 1955

Pterospermopsis spp.

Senegalinium laevigatum (Malloy, 1972) Bujak and Davies, 1983

Senegalinium spp.

Spinidinium? sp.

Spinidinium cf. S.densispinatum Stanley, 1965

Spinidinium? sp. A

Spinidinium sp. B

Spinidinium sp. C

Spiniferites cf. S. lenzii Below, 1982c

Spiniferites cornutus subsp. laevimurus (Davey and Williams, 1966a) Lentin and Williams, 1973.

Spiniferites cornutus subsp. A

Spiniferites fluens (Hansen, 1977) Stover and Williams, 1987

Spiniferites ramosus subsp. ramosus Ehrenberg, 1838

Spiniferites septatus (Cookson and Eisenack, 1967b) McLean, 1971

Spiniferites cf. S.? dentatus (Gocht, 1959) Lentin and Williams, 1973

Spiniferites spp.

Spiniferites supparus (Drugg, 1967) Sarjeant, 1970

Spiniferites twistringiensis Maier, 1959. Fensome et al., 1990a

Spiniferites wetzelii (Deflandre, 1937b) Sarjeant, 1970a

Subtilisphaera?pirnaensis (Alberti, 1959b) Jain and Millepied, 1973

Subtilisphaera sp.

Subtilisphaera zawia Below, 1981a

Systematophora placacantha (Deflandre and Cookson, 1955) Davey et al., 1969 emend. May, 1980

Tanyosphaeridium regulare Davey and Williams, 1966b
Tanyosphaeridium salpinx Norvick, in Norvick and Burger, 1976

Tanyosphaeridium $\mathrm{sp}$.

Tanyosphaeridium variecalamus Davey and Williams, 1966b

Tanyosphaeridium xanthiopyxides (O. Wetzel, 1933b) Stover and Evitt, 1978

Tasmanites $\mathrm{sp}$

Thalassiphora pelagica (Eisenack, 1954b) Eisenack and Gocht, 1960 emend. Benedek and Gocht, 1981a

Trichodinium castanea (Deflandre, 1935) Clarke and Verdier, 1967

Trichodinium cf. T. hirsutum Cookson, 1965b

\section{APPENDIX B}

Alphabetical list of spore and pollen taxa recorded in this study.

Arecipites sp. Brevicolporites sp.

Buttinia andreevi Boltenhagen, 1967

Chenopodipollis sp.Circulina parva Brenner, 1963

Corollina jardinei Herngreen, 1972

Corollina torosus (Reissinger) Klaus 1955 emend. Cornet and Traverse, 1975

Corollina? sp.

Corrugatisporites ivoriensis Jardiné and Magloire, 1965

Cyathidites minor Couper, 1963

Deltoidospora sp.

Dicolpites sp.

Elaterosporites castelaini Jardiné and Magloire, 1965

Ephedripites multicostatus Brenner, 1963

Ephedripites sp. 1

Ephedripites sp. 2

Ephedripites sp. 3

Ephedripites spp.

Foveotricolpites sp.

Foveotriletes margaritae Germeraad, Hopping and Muller, 1968

Granulatisporites sp.

Laevigatosporites gracilis Wilson and Webster, 1946

Leiotriletes spp.

Longapertites vaneendenburgi Germeraad, Hopping and Muller, 1968

Monocolpopollenites sp.

Monosulcites spp.

Multiporopollenites sp. 1

Multiporopollenites sp. 2

Parvisaccites cf. P. radiatus Couper, 1963

Proxapertites? sp.

Retitriporites sp.

Rugulatisporites caperatus van Hoeken-Klinkenberg, 1964

Striamonocolpites $\mathrm{sp}$.

Striatopollis sp.

Toroisporis $\mathrm{sp}$.

Tricolpites reticulominutus Jardiné and Magloire, 1965

Tricolpites sp. 1

Tricolpites sp. 2

Tricolpites sp. 3

Tricolpites sp. 4

Tricolpopollenites spp.

Tricolporopollenites spp.

Trilete spore

Triorites africaensis Jardiné and Magloire, 1965

Triorites cf. T africaensis Jardiné and Magloire, 1965

Triporopollenites $\mathrm{sp}$

Verrutriletes sp. 
Intentionally left blank 

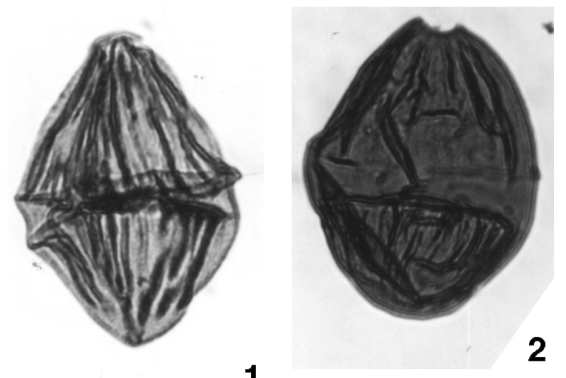

1
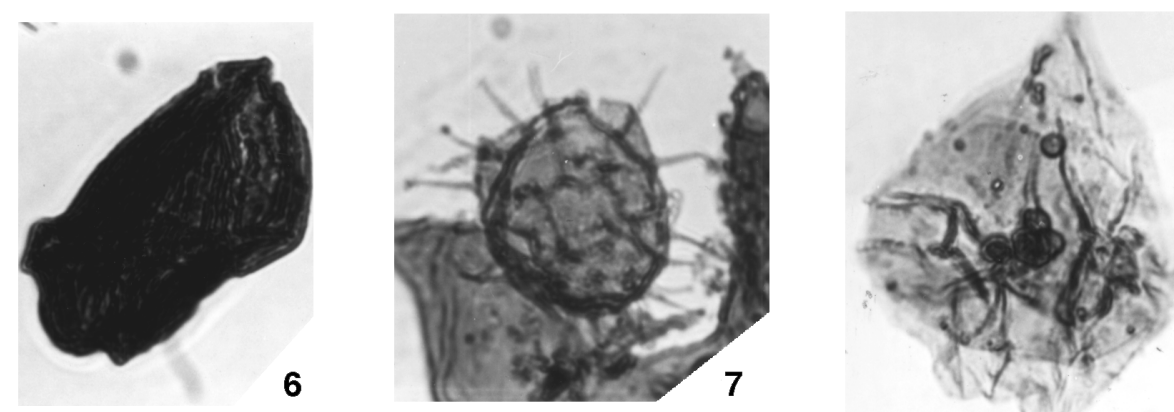

8

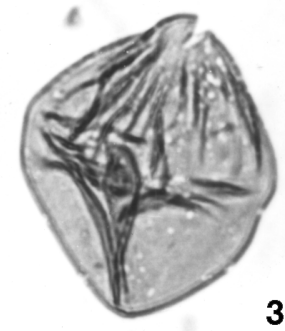

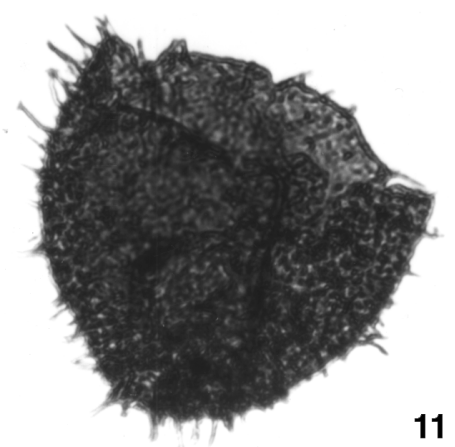
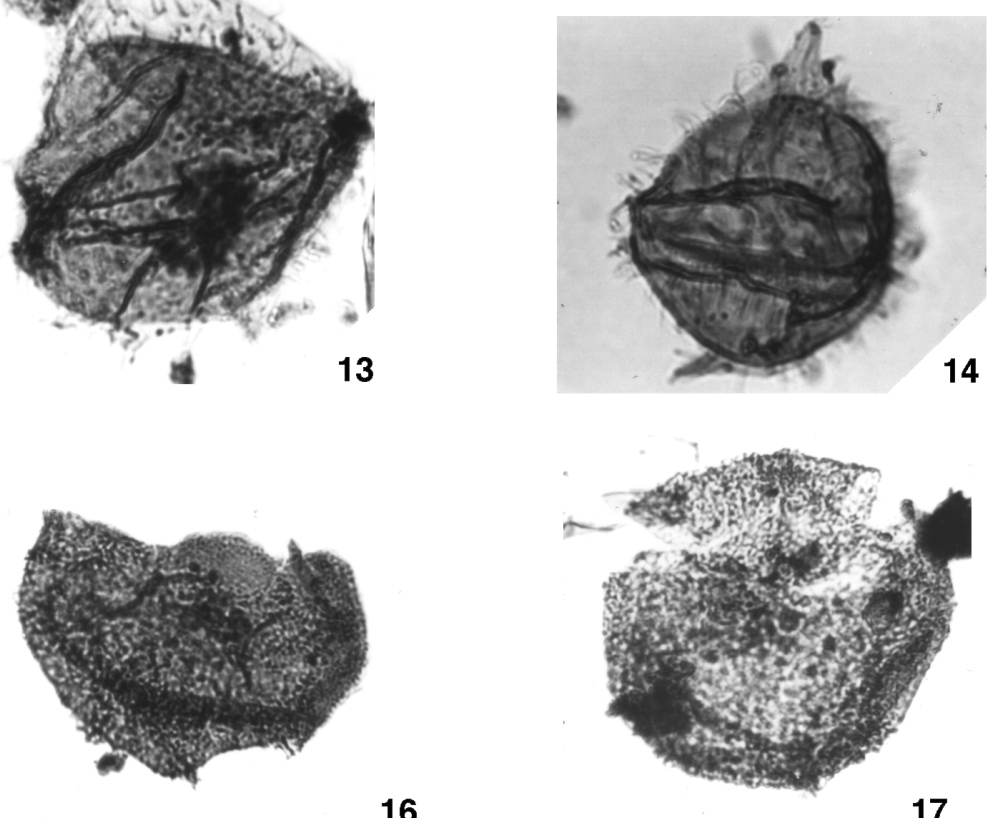

16

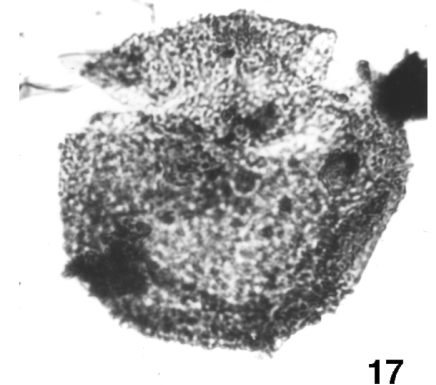

13

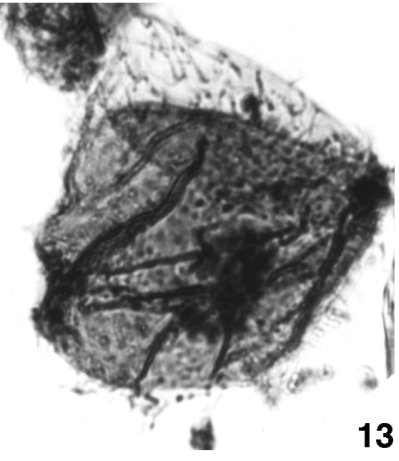

$\bullet$
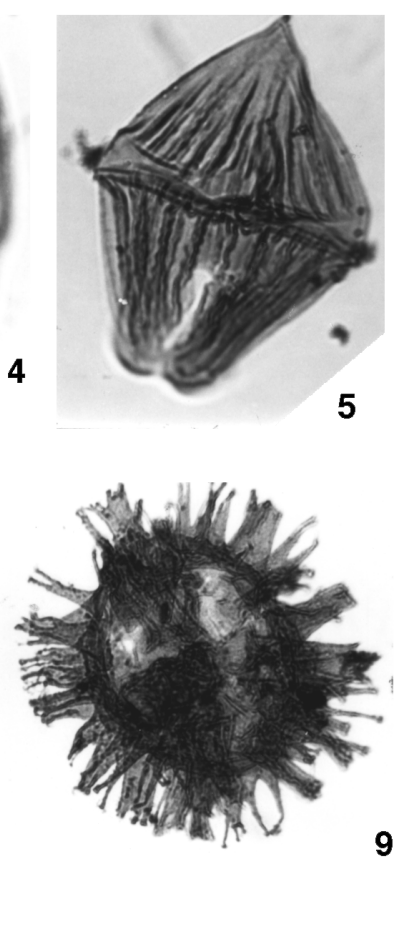
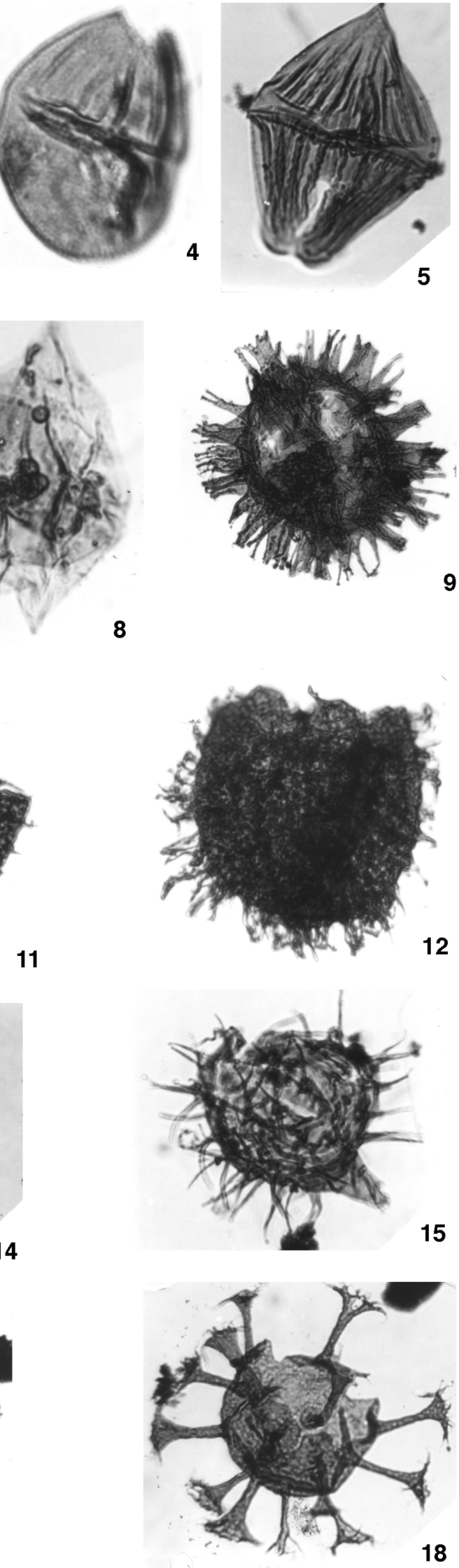
Plate 1. All dinoflagellate cysts and acritarchs illustrated in Plates 1 to 9 are from Hole 959D, unless otherwise stated. All coordinates quoted in Plates 1 to 10 can be located on the Lovins Micro-Slide Field Finder (Catalog No. 7100). 1. Dinogymnium acuminatum Evitt et al., 1967, Sample 159-959D-65R-6, 10-13 cm (1031.7 mbsf), P21 (4, -2.5), length: 56 بm. 2. Dinogymnium cretaceum (Deflandre, 1935) Evitt et al., 1967, Sample 159-959D-67R-1, 10-14 cm (1043.4 mbsf), J10 (-4, -2.5), length: 56 m. 3, 4. Alysogymnium euclaense (Cookson and Eisenak, 1970) Lentin and Vozzhennikova, 1990, Sample 159-959D-56R-2, 80-82 cm (939.70 mbsf), (3) G28 (-3, -4), length: $48 \mu \mathrm{m}$, (4) T10 (5, -3), length: $43.2 \mu \mathrm{m}$. 5. Dinogymnium undulosum Cookson and Eisenack, 1970, Sample 159-959D-49R-4, 99-102 cm (875.69 mbsf), Q20 (-4, -3), length: $78.4 \mu \mathrm{m}$. 6. Dinogymnium westralium (Cookson and Eisenack, 1958) Evitt, et al., 1967, emend. May, 1977, Sample 159-959D-64R-5, 89-93 cm (1021.59 mbsf), T3 (0, 0), length: $56 \mu \mathrm{m}$. 7. Tanyosphaeridium salpinx Norvick, in Norvick and Burger, 1976, Sample 159-959D-67R-1, 10-14 cm (1043.4 mbsf), P33 $(1,2)$, central body: $28.8 \times 24 \mu \mathrm{m}$, processes length: $11.2 \mu \mathrm{m}$. 8. Subtilisphaera zawia Below, 1981, Sample 159-959D-65R-6, 10-13 cm (1031.70 mbsf), J29 (-3, 2), length: 67.2 $\mu$ m. 9. Florentinia ferox (Deflandre, 1937) Duxbury, 1980, Sample 159-959D-64R-5, 89-93 cm (1021.59 mbsf), M9 $(-4,-4)$, total length: $115 \mu \mathrm{m}$. 10. Cyclonephelium vannophorum Davey 1969, antapical view. Note the precingular paraplates and part of the archeopyle suture. Sample 159-959D-67R-1, 10-14 cm (1043.4 mbsf), Q36/Q37, maximum length of the fragment: 60.8 $\mu \mathrm{m}$. 11. Circulodinium distinctum (Deflandre and Cookson, 1955) Jansonius, 1986, Sample 159-959D-64R-5, 89-93 cm (1021.59 mbsf), K33 (-4, -3), archeopyle length: $70.4 \mu \mathrm{m}$. 12. Circulodinium sp. A., Sample 159-959D-64R-5, 89-93 cm (1021.59 mbsf), F4 (-4, -4), archeopyle length: $51.2 \mu$ m. 13, 14. Palaeohystrichophora infusorioides Deflandre, 1935, (13) Sample 159-960A-21R-1, 43-48 cm (184.53 mbsf), D9 (4, -3), length: 52.8 $\mu$ m, (14) 962B-9H-1, 69-73 cm (74.69 mbsf), P12 (-3, -3.5), length: $60.8 \mu \mathrm{m}$. 15. Coronifera oceanica Cookson and Eisenack, 1958 emend. May, 1980, Sample 159-959D-67R-1, 10-14 cm (1043.4 mbsf), G31 (-3, -3), central body breadth: $48 \mu \mathrm{m}$, antapical horn: $16 \mu \mathrm{m} .16$, 17. Canningia senonica Clarke and Verdier, 1967, Sample 159959D-65R-6, 10-13 cm (1031.70 mbsf), (16) F29 $(-4,-4)$, breadth: $56 \mu \mathrm{m},(17) \mathrm{H} 22(2.5,4)$, breath: $56 \mu \mathrm{m}$. 18. Oligosphaeridium complex (White, 1842) Davey and Williams, 1966, Sample 159-959D-64R-5, 89-93 cm (1021.59 mbsf), H19 (3, -1), central body breadth: $54 \mu \mathrm{m}$, length of processes: 24 to $27.2 \mu \mathrm{m}$. 

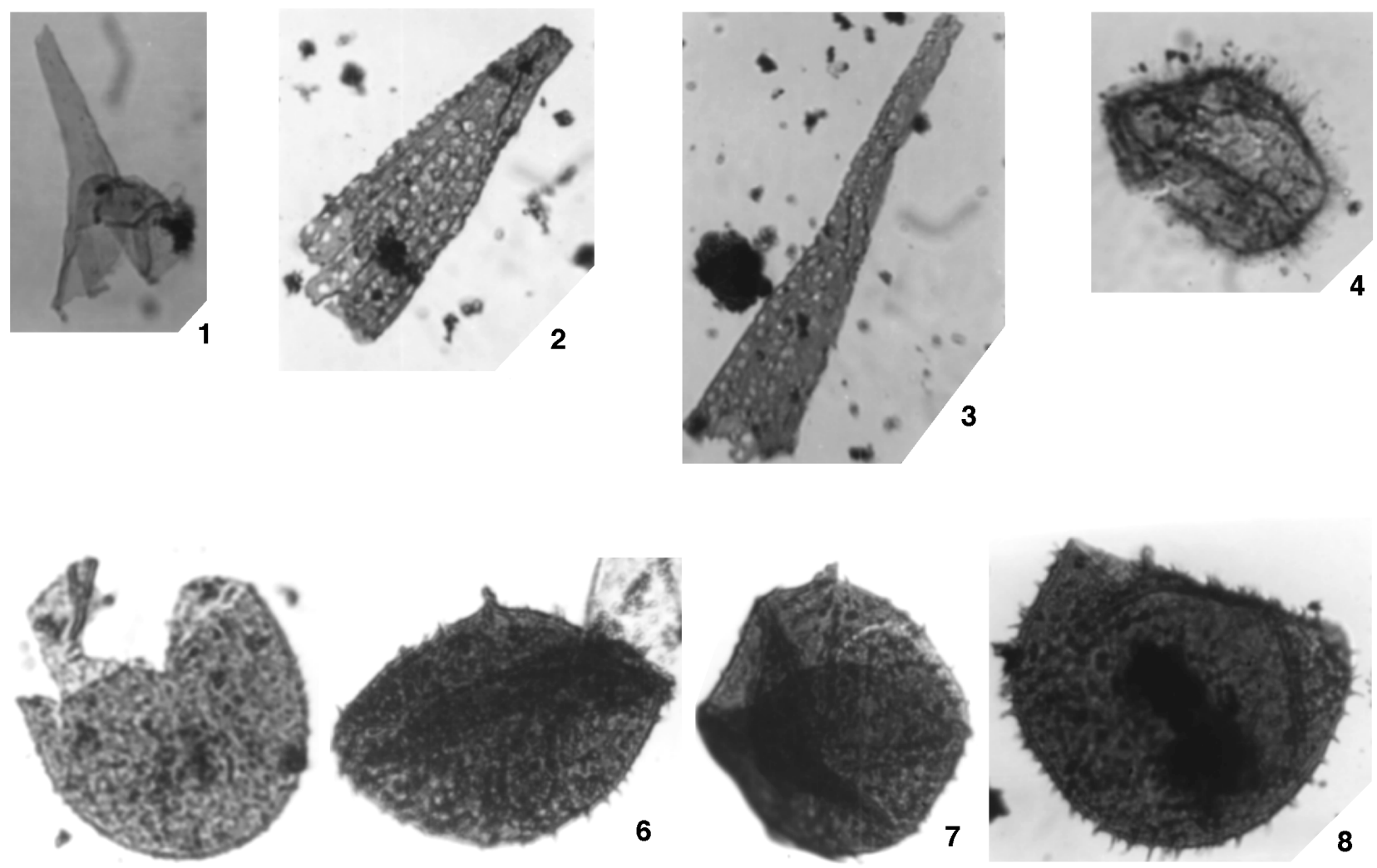

5
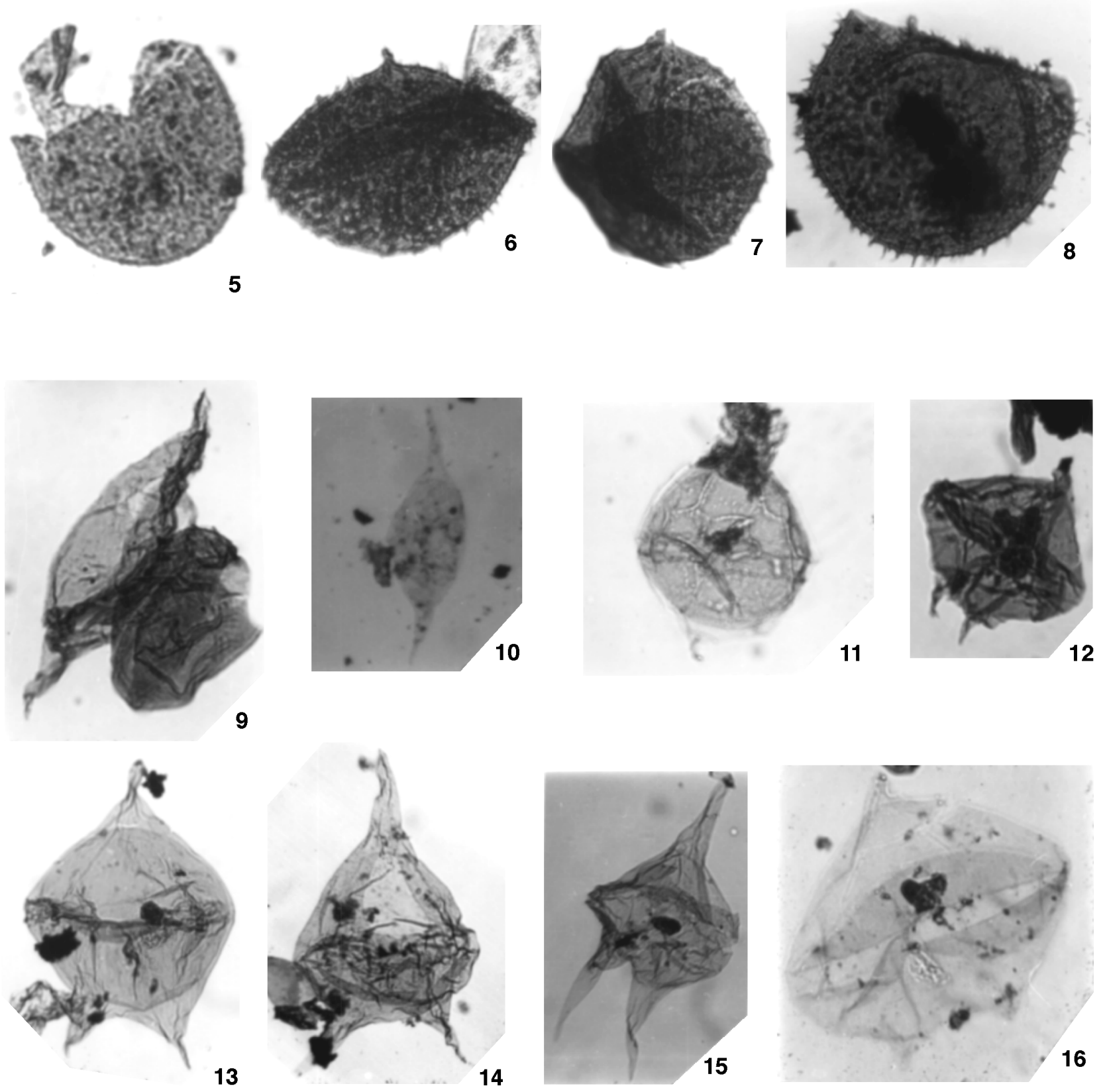
Plate 2. 1. Odontochitina operculata (O. Wetzel, 1933) Deflandre and Cookson, 1955, Sample 159-959D-49R-4, 99-102 cm (875.69 mbsf), A10/A11, length: $65.6 \mu \mathrm{m}$. 2, 3. Odontochitina porifera Cookson, 1956, Sample 159-959D-62R-1, 21-24 cm (995.61 mbsf), (2) M31 (-2.5, 0), length: $84.8 \mu \mathrm{m},(3) \mathrm{C} 7(-2,-1)$, length $113.6 \mu \mathrm{m}$. 4. Cometodinium sp. cf. C.?whitei (Deflandre and Courteville, 1939) Stover and Evitt, 1978, Sample 159-959D-67R-1, 10-14 cm (1043.4 mbsf), E6 (-2.5, 0), breadth: $45 \mu \mathrm{m}$. 5. Kallosphaeridium ?ringnesiorum (Manum and Cookson, 1964) Helby, 1987, Sample 159-959D-62R-1, 21-24 cm (995.61 mbsf), H6 (-1, 3), breadth: $41.6 \mu \mathrm{m}$. 6-8. Trichodinium castanea (Deflandre, 1935) Clarke and Verdier, 1967, Sample 159-959D-60R-2, 100-104 cm (978.6 mbsf), (6) K22 (-4, 5), breadth: $80 \mu \mathrm{m}$, (7) B8 (0, 4), breadth; $64 \mu \mathrm{m}$, (8) S8 (3.5, 4), breadth: 54.4 um. 9. Palaeocystodinium lidiae (Gorka, 1963) Davey, 1969, Sample 159-959D-60R-2, 100-104 cm (978.6 mbsf), H15 (0, 0), length: $115.2 \mu \mathrm{m}$. 10. Palaeocystodinium sp. A of Bujak and Williams, 1983, Sample 159-959D-53R-4, 67-70 cm (912.46 mbsf), P26 (4.5, 4.5), length: $192 \mu \mathrm{m}$. 11. Spinidinium ?cf. S. densispinatum Stanley, 1965, Sample 159-959D-60R-2, 100$104 \mathrm{~cm}$ (978.6 mbsf), B21 (0, 4), length: 65 mm. 12. Geiselodinium psilatum Jain and Millepied, 1973, Sample 159-959D-60R-2, 100-104 cm (978.6 mbsf), M7 $(-1,-3)$, breadth: $56 \mu \mathrm{m}$. 13. Cerodinium boloniense (Riegel, 1974) Lentin and Williams, 1989, Sample 159-959D-59R-2, 45-50 cm (968.45 mbsf), R9/R8, length: $131.2 \mu \mathrm{m}$. 14. Cerodinium obliquipes (Deflandre and Cookson, 1955) Lentin and Williams, 1987, Sample 159-959D-51R-5, 53-56 cm (895.73 mbsf), L23 (-2.5, 4), length: $160 \mu \mathrm{m}$. 15. Cerodinium diebelii (Alberti, 1959) Lentin and Williams, 1987, Sample 159-959D-51R-2, 55-57 cm (891.25 mbsf), H6 (1.5, 1.5), length: $141.6 \mu \mathrm{m}$. 16. Phelodinium gaditanum (Riegel, 1974) Lentin and Williams, 1981 emend. Riegel and Sarjeant, 1982, Sample 159-959D-50R-4, $105-108 \mathrm{~cm}$ (885.45 mbsf), H18 (1, 2.5), breadth: $86.4 \mu \mathrm{m}$. 

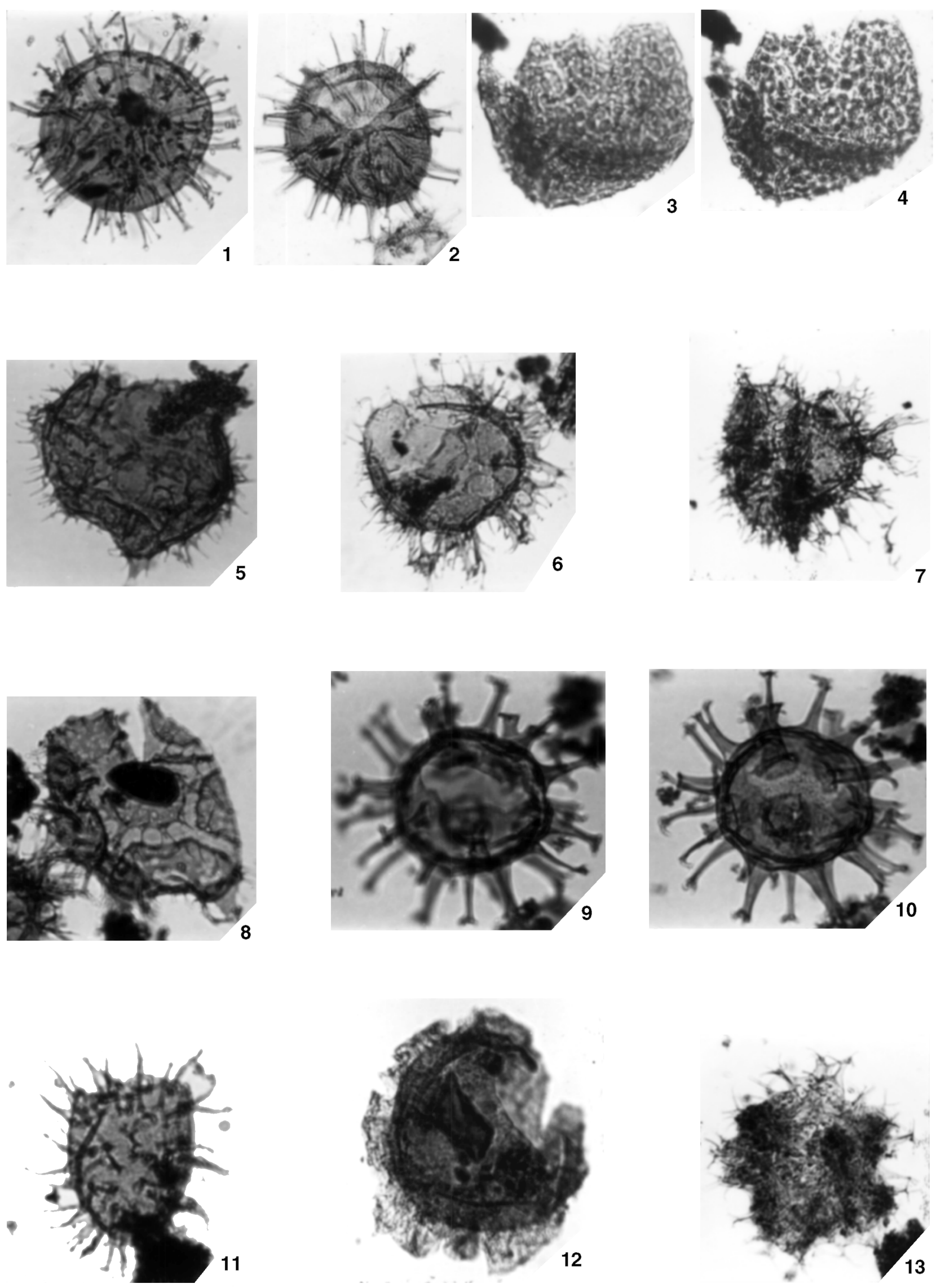
Plate 3. 1, 2. Exochosphaeridium bifidum (Clarke and Verdier, 1967) Clarke et al., 1968, Sample 159-959D-48R-5, $37-41 \mathrm{~cm}(866.97 \mathrm{mbsf})$, L6 (-3, 3), central body diameter: $56 \mu \mathrm{m}$. 3, 4. "Chytroeisphaeridia everricula" of Wilson (1974), Sample 159-959D-59R-2, 45-50 cm (968.45 mbsf), R8 (-2, -1), breadth 75.2 $\mu \mathrm{m}$, (3) high focus, (4) low focus. 5. Areoligera senonensis Lejeune-Carpentier, 1938, Sample 159-959D-50R-4, 105-108 cm (885.45 mbsf), R10 (0, 1), breadth: $59.2 \mu \mathrm{m}$. 6, 7. Areoligera coronata (O. Wetzel, 1933b) Lejeune-Carpentier, 1938, (6) Sample 159-959D-52R-1, 18-20 cm (898.98 mbsf), D5/D4, central body breadth: $51.2 \mu \mathrm{m}$, (7) Sample 159-959D-57R-1, 31-34 cm (947.41 mbsf), A4 (-1, -1$)$, central body breadth: $62.4 \mu \mathrm{m}$. 8. Systematophora placacantha (Deflandre and Cookson, 1955) Davey et al., 1969 emend. 1980, Sample 159-959D-50R-4, 105-108 cm (885.45 mbsf), R11 (0, -3), length: 56 m. 9, 10. Hystrichosphaeridium tubiferum (Ehrenberg, 1838), Sample 159-959D-50R-4, 105-108 cm (885.45 mbsf), (9) high focus, G30 ( -3 , 3), central body diameter: 40 $\mu \mathrm{m}$, length of processes up to $16 \mu \mathrm{m},(10)$ same specimen, low focus. 11. Tanyosphaeridium regulare Davey and Williams, 1966, Sample 159-959D-58R-1, 2-5 $\mathrm{cm}(956.82 \mathrm{mbsf}), \mathrm{G} 19(4,4)$, central body: $35.2 \mu \mathrm{m} \times 27 \mu \mathrm{m}$. 12. Cordosphaeridium fibrospinosu Davey and Williams, 1966, Sample 159-959D-56R-2, 80-82 cm (939.70 mbsf), K23 (4, 3), central body diameter: $75.2 \mu \mathrm{m}$. 13. Spiniferites supparus (Drugg, 1967) Sarjeant, 1970, Sample 159-959D-56R-2, 80-82 cm (939.70 mbsf), G23 (3, 5), length: $80 \mu \mathrm{m}$. 

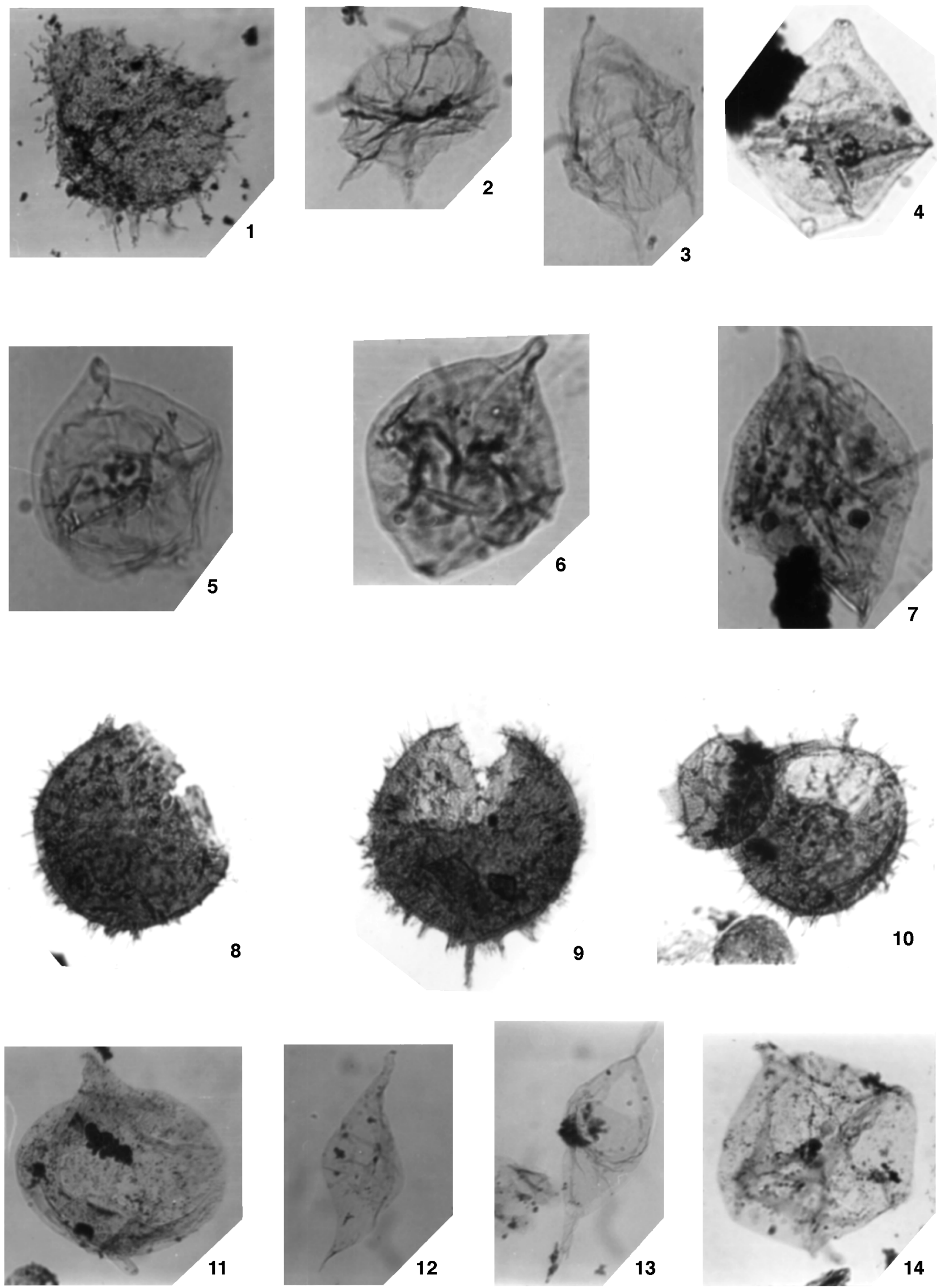
Plate 4. 1. Hystrichodinium pulchrum Deflandre 1935, Sample 159-959D-62R-1, 21-24 cm (995.61 mbsf), B16 (0, 2), length: 70 m. 2, 3. Cerodinium sp. A. Sample 159-959D-50R-1, 105-108 cm (880.95 mbsf), T20 (3, -3), (2) length: $57.6 \mu \mathrm{m}$, (3) length: $72 \mu \mathrm{m} .4$. Alterbidinium varium Kirsch, 1991, Sample 159959D-54R-1, 37-39 cm (918.47 mbsf), K7 (-5, -4), length: 49.6 m. 5-7. Manumiella raijae (Kjellström, 1973) Bujak and Davies, 1983, Sample 159-959D54R-1, 37-39 cm (918.47 mbsf), (5) M30 (1, 0), length: $49.6 \mu \mathrm{m},(6) \mathrm{N} 4(-2,-1)$, length: $57.6 \mu \mathrm{m},(7) \mathrm{U} 34(4,3)$, length: 67.2 $\mu \mathrm{m} .8-10.9$. Trichodinium cf. T. hirsutum Cookson, 1965, Sample 159-959D-52R-1, 18-20 cm (898.98 mbsf), (8) S10 (3, 2.5), length: $96 \mu \mathrm{m},(9)$ D25 (1, -3), central body diameter: $73.6 \mu \mathrm{m} \times$ $78.4 \mu \mathrm{m}$, (10) M31 $(1,1)$, central body diameter: $72 \mu \mathrm{m}$, processes: $6.4 \mu \mathrm{m}-11.2 \mu \mathrm{m}$, apical process: $16 \mu \mathrm{m}$. 11. Andalusiella gabonensis Stover and Evitt, 1978, Sample 159-959D-52R-1, 18-20 cm (898.98 mbsf), A31 (-2, -2.5), length: $115.2 \mu \mathrm{m}$. 12. Palaeocystodinium sp. B, Sample 159-959D-52R-1, 18-20 cm (898.98 mbsf), G24 (-2, -3), length: $121.6 \mu \mathrm{m}$. 13. Palaeocystodinium australinum (Cookson, 1965) Lentin and Williams, 1976, Sample 159-959D-49R-4, 99$102 \mathrm{~cm}(875.69 \mathrm{mbsf})$, C5 (5, 4), length: $168 \mu \mathrm{m}$. 14. Senegalinium laevigatum (Malloy, 1972) Bujak and Davies, 1983, Sample 159-959D-51R-5, 53-56 cm (895.73 mbsf), M31 (2, -4), breadth: $75.2 \mu \mathrm{m}$. 

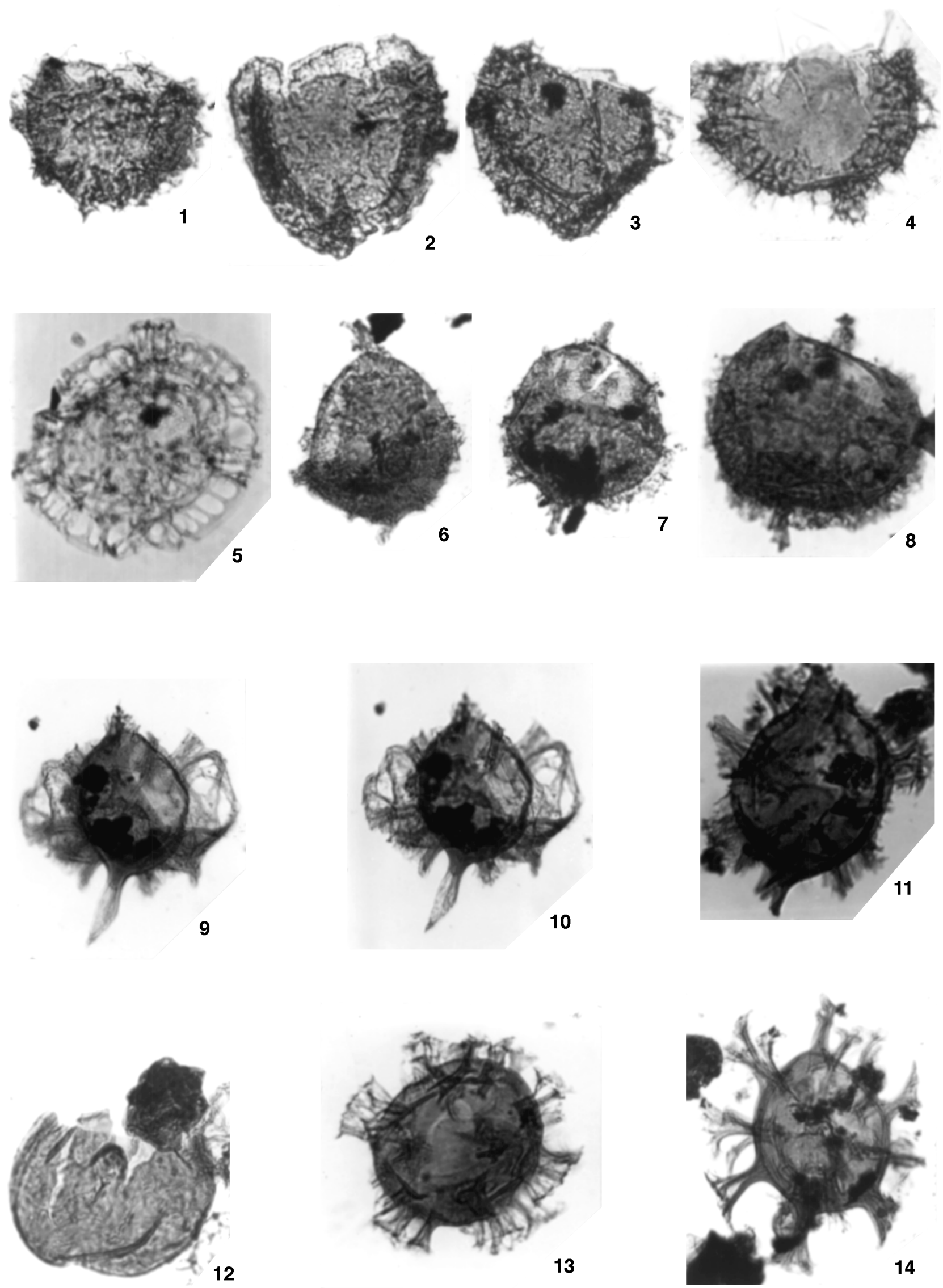
Plate 5. 1. Cyclonephelium crassimarginatum Cookson and Eisenack, 1974, Sample 159-959D-57R-1, $31-34 \mathrm{~cm}$ (947.41 mbsf), 57/58, overall breadth: 75 um. 2. Cyclonephelium compactum Deflandre and Cookson, 1955, Sample 159-959D-51R-5, 53-56 cm (895.73 mbsf), B17 (-4, -4), breadth: 60.8 $\mu$ m. 3. Cyclonephelium cf. C. paucispinum Davey, 1969, Sample 159-959D-51R-5, 53-56 cm (895.73 mbsf), K3 (2, 5), breadth: 67.2 $\mu$ m. 4. Cyclonephelium sp. A., Sample 159-959D-49R-4, 99-102 cm (875.69 mbsf), A2 (5, 5), archeopyle breadth: 64 um. 5. Membranilarnacia?sp. Morgenroth, 1968, Sample 159-959D-51R-5, 53$56 \mathrm{~cm}$ (895.73 mbsf), F14 (-1.5, -1.5), central body: $43.2 \mu \mathrm{m} \times 49.6 \mu \mathrm{m}$. 6-8. Kenleyia leptocerata Cookson and Eisenack, 1965, Sample 159-959D-51R-5, 53-

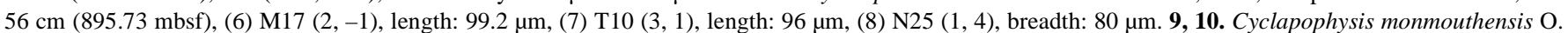
Wetzel, 1933 emend. Sarjeant, 1985, Sample 159-959D-51R-2, 55-57 cm (891.25 mbsf), (9) high focus, F22 (2, 3), length: 120 $\mu \mathrm{m},(10)$ same specimen, low focus. 11. Cordosphaeridium sp. A., Sample 159-959D-50R-4, 105-108 cm (885.45 mbsf), E31 (-2, 2) length: $105.6 \mu \mathrm{m}$. 12. Chytroeisphaeridia sp. A, Sample 159-959D-50R-1, 105-108 cm (880.95 mbsf), C33 (3, 4), breadth: 88 m. 13. Cordosphaeridium exilimurum Davey and Williams, 1966, Sample 159-959D50R-1, 105-108 cm (880.95 mbsf), J30 $(-4,2)$, central body: $64 \mu \mathrm{m} \times 56 \mu \mathrm{m}$, processes up to $19.2 \mu \mathrm{m}$. 14. Cordosphaeridium cf. C. inodes (Klumpp, 1953) Eisenack, 1963 emend. Morgenroth, 1968, Sample 159-959D-50R-4, 105-108 cm (885.45 mbsf), C6 (2, -4), central body $72 \mu \mathrm{m} \times 57.6 \mu \mathrm{m}$. 

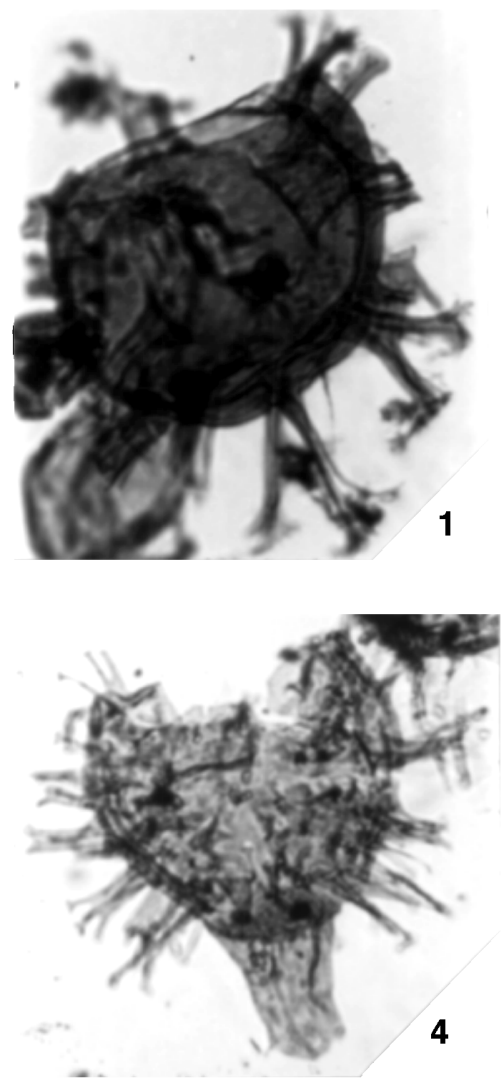
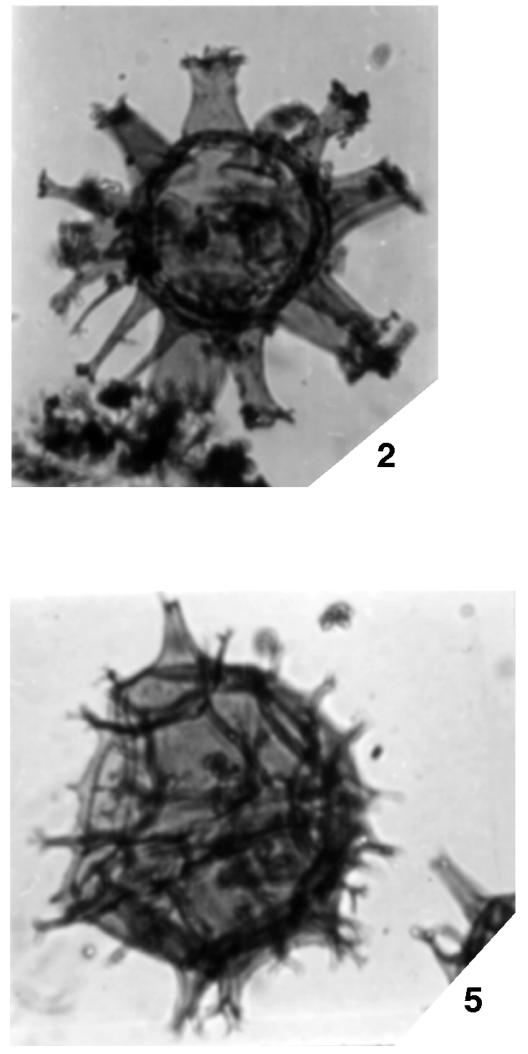
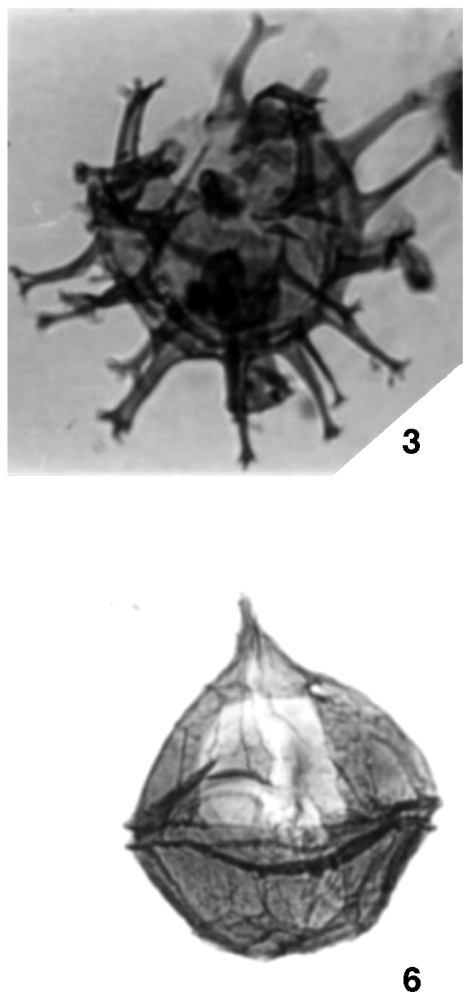
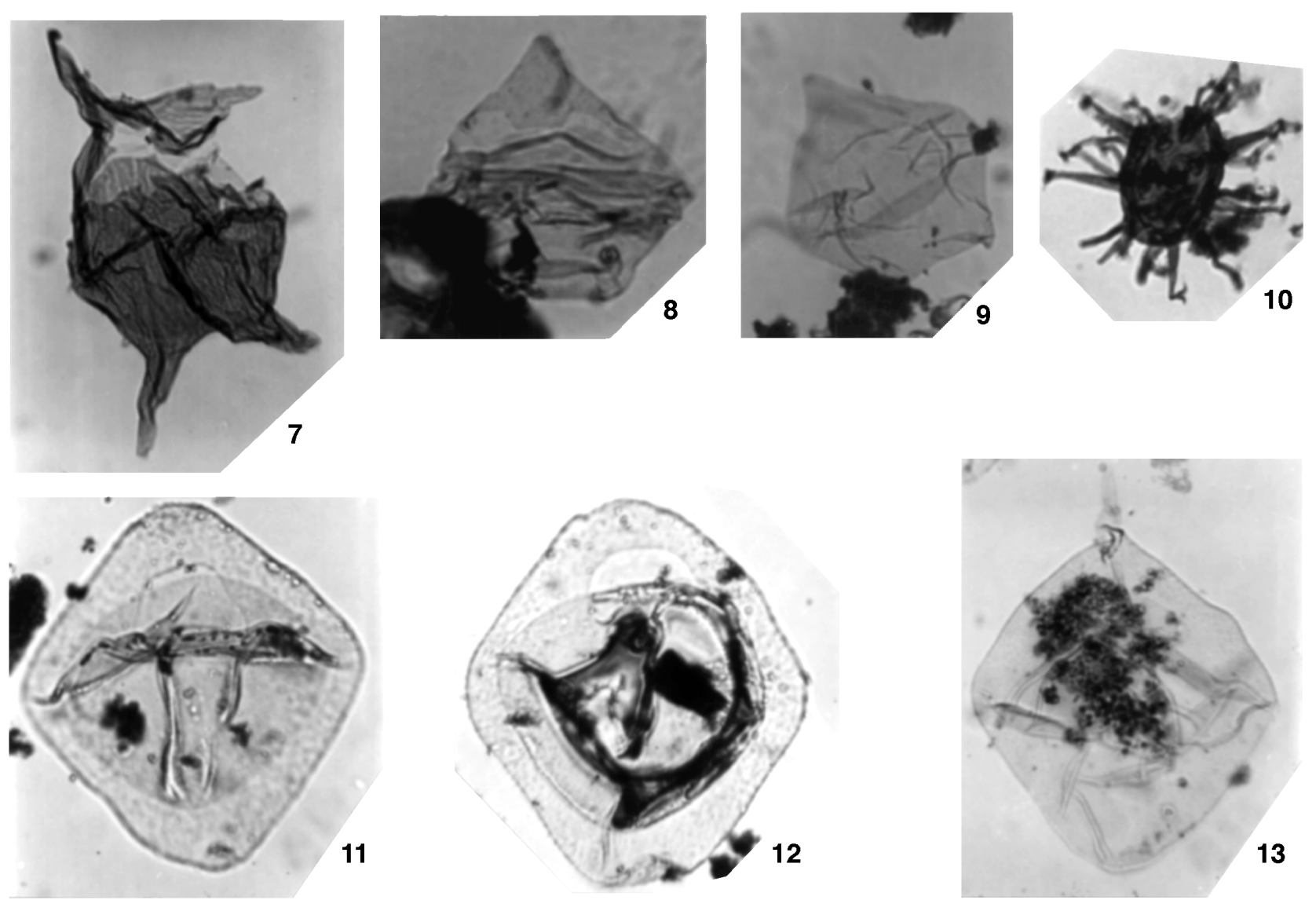
Plate 6. 1. Cordosphaeridium inodes (Klumpp, 1953) Eisenack, 1963 emend. Morgenroth, 1968, Sample 159-959D-50R-4, $105-108$ cm (885.45 mbsf), C19 (3, -4), central body: $73.6 \mu \mathrm{m} \times 64 \mu \mathrm{m}$. 2. Florentinia cooksoniae (C. Singh, 1971) Duxbury, 1980, Sample 159-959D-48R-5, 37-41 cm (866.97 mbsf), L8 (-3, -4), central body diameter: $40 \mu \mathrm{m}$. 3. Diphyes colligerum (Deflandre and Cookson, 1955) Cookson, 1965a emend. Goodman and Witmer, 1985, Sample 159959D-50R-1, 105-108 cm (880.95 mbsf), U30 (1,-1.5), overall breadth: $72 \mu \mathrm{m}$. 4. Diphyes cf. D. colligerum (Deflandre and Cookson, 1955) Cookson, 1965 emend. Goodman and Witmer, 1985, Sample 159-959D-48R-5, 37-41 cm (866.97 mbsf), E18 (0, -3), archeopyle breadth: $48 \mu \mathrm{m} .5$. Spiniferites cornutus subsp. laevimurus (Davey and Williams, 1966) Lentin and Williams, 1973, Sample 159-959D-48R-5, 37-41 cm (866.97 mbsf), Q20 (-4, 3), length: 67.2 m. 6. Cribroperidinium wetzelii (Lejeune-Carpentier, 1939) Helenes, 1984, Sample 159-959D-50R-1, 105-108 cm (880.95 mbsf), D-5/E-5, length: 104 $\mu$ m. 7. Cerodinium striatum (Drugg, 1967) Lentin and Williams, 1987, Sample 159-959D-50R-1, 105-108 cm (880.95 mbsf), B29 (2, -3), length: $84.8 \mu \mathrm{m} .8$. Pierceites pentagona (May, 1980) Habib and Drugg, 1987, Sample 159-959D-49R-4, 99-102 cm (875.69 mbsf), C30/C29, length: $23 \mu \mathrm{m}$. 9. Lejeunecysta sp., Sample 159959D-49R-4, 99-102 cm (875.69 mbsf), A18 (-5, -5), breadth: $51.2 \mu$ m. 10. Hystrichosphaeridium cf. H. tubiferum (Ehrenberg, 1838), Sample 159-959D-49R2, 99-102 cm (872.69 mbsf), K26 (2.5, 1), central body breadth: $24 \mu \mathrm{m}$. 11-13. Manumiella seelandica (Lange, 1969) Bujak and Davies, 1983 emend. Firth, 1987, Sample 159-959D-49R-4, 99-102 cm (875.69 mbsf), (11) J8 (2, 2.5), length: $91.2 \mu \mathrm{m},(12) \mathrm{K} 32$ (-2, -2), length: $96 \mu \mathrm{m},(13) \mathrm{C} 21$ (1.5, 1$)$, length: 120 $\mu \mathrm{m}$. 

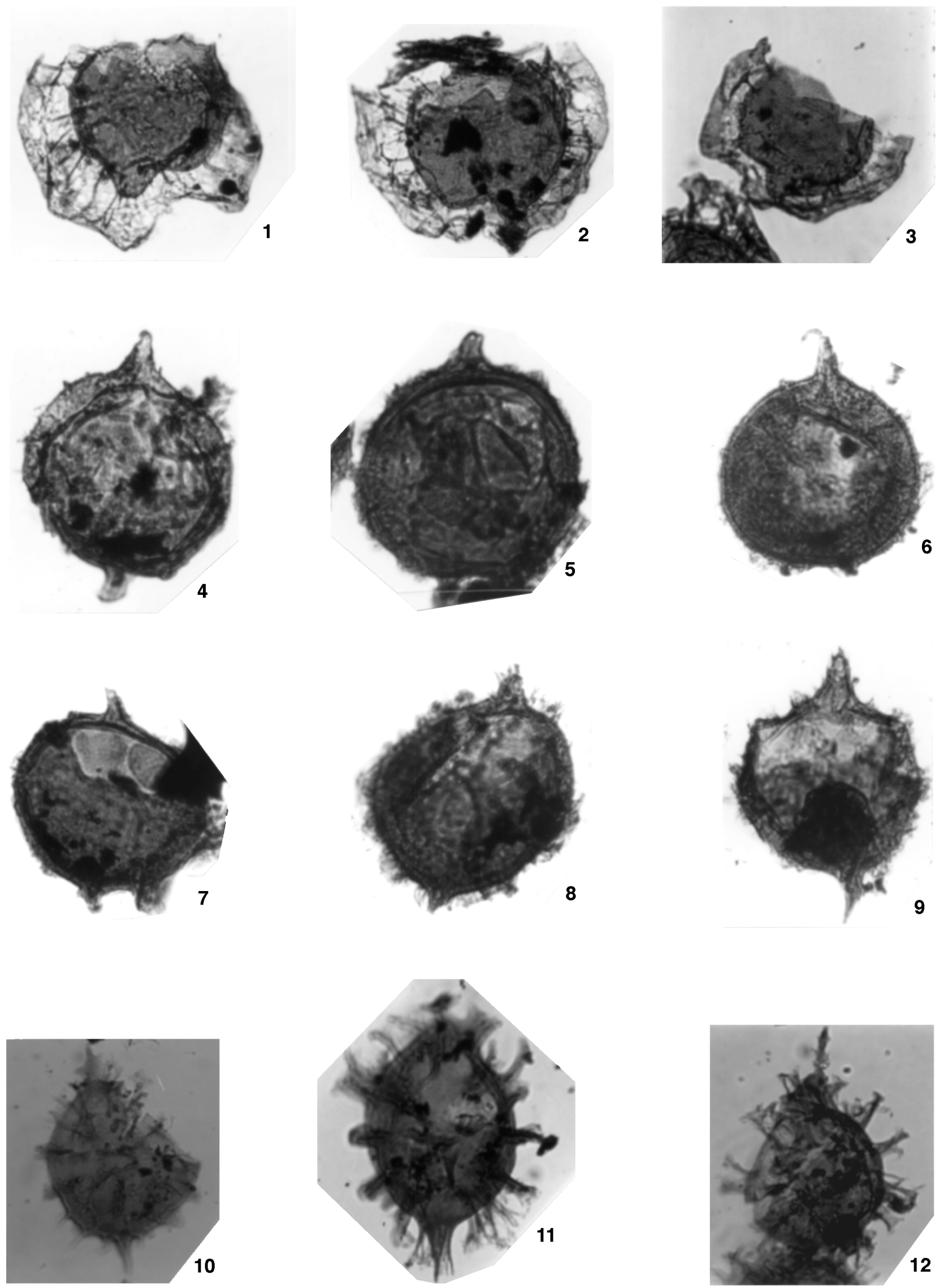
Plate 7. 1-3. Glaphyrocysta perforata Hultberg and Malmgren (1985), Sample 159-959D-49R-4, 99-102 cm (875.69 mbsf), (1) P27 (0, 0), central body breadth: $56 \mu \mathrm{m}$, (2) A25 (-3, -3), central body breadth: $67.2 \mu \mathrm{m}$, (3) F29 (1, 0), central body breadth: 59.2 $\mu \mathrm{m}$. 4-7. Kenleyia sp. A, Sample 159-959D-49R-4, 99-102 cm (875.69 mbsf), (4) L3 (2, 3), length: $78.4 \mu \mathrm{m},(5) \mathrm{G} 12$ (5, 5), length: $76.8 \mu \mathrm{m},(6) \mathrm{S} 4(4,-2)$, length: $83.2 \mu \mathrm{m},(7)$ U2 (4, -2), length: $80 \mu \mathrm{m} .8$, 9. Kenleyia cf. K. lophophora Cookson and Eisenack, 1965, Sample 159-959D-49R-4, 99-102 cm (875.69 mbsf), (8) K33 (-1, -1), length: $92.8 \mu \mathrm{m}$. (9) A24 (0, 4), length: $99.2 \mu \mathrm{m}$. 10, 11. Fibrocysta bipolaris (Cookson and Eisenack, 1965) Stover and Evitt, 1978, Sample 159-959D-48R-5, $37-41 \mathrm{~cm}(866.97 \mathrm{mbsf})$, (10) F13 (0, -4), length: $96 \mu \mathrm{m},(11)$ A32 (-3, 5), length: $92.8 \mu \mathrm{m}$. 12. Fibrocysta cf. F. bipolaris (Cookson and Eisenack, 1965) Stover and Evitt, 1978, Sample 159959D-48R-5, 37-41 cm (866.97 mbsf), F33 (-3, -2), central body breadth: $48 \mu \mathrm{m}$. 

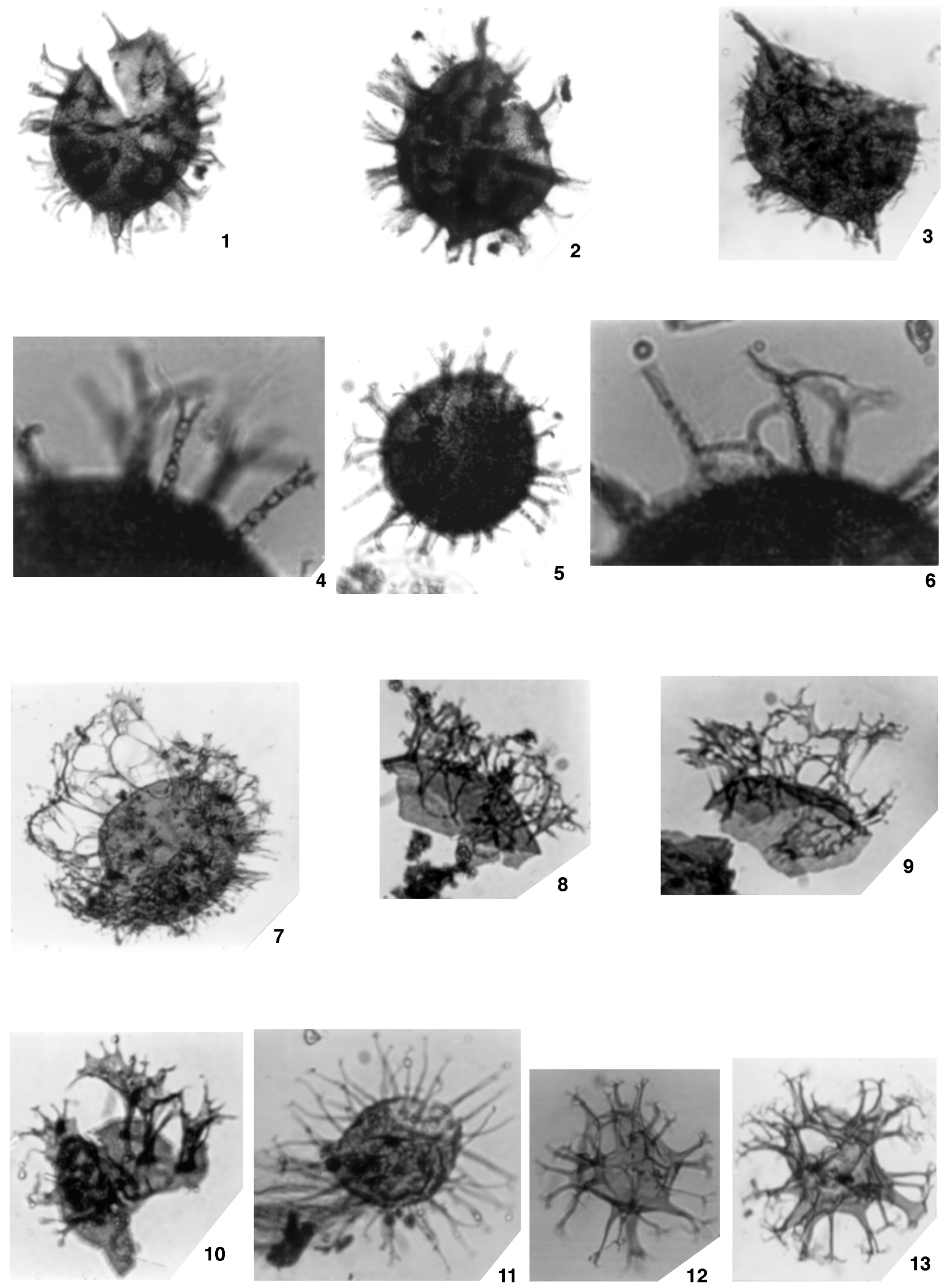
Plate 8. 1, 2. Fibrocysta vectensis (Eaton, 1976) Stover and Evitt, 1978, Sample 159-959D-48R-5, 37-41 cm (866.97 mbsf), (1) D26 (2, 4), length: 64 um, (2) A29 (4, 3), length: $83.2 \mu \mathrm{m}$. 3. Fibrocysta bipolaris (Cookson and Eisenack, 1965) Stover and Evitt, 1978, Sample 159-959D-48R-5, 37-41 cm (866.97 mbsf), C15 (3, 1), length: 100.8 Mm. 4-6. Spiniferites septatus, (Cookson and Eisenack, 1967) McLean, 1971, Sample 159-959D-48R-5, 37-41 cm (866.97 mbsf), (4) F31 $(4,1)$, processes length: 10-14 $\mu \mathrm{m},(5)$ same specimen, overall breadth: $73 \mu \mathrm{m}$, (6) same specimen, processes length: 10-14 $\mu \mathrm{m}$. 7. Glaphyrocysta exuberans (Deflandre and Cookson, 1955) Stover and Evitt, 1978, Sample 159-959D-48R-5, 37-41 cm (866.97 mbsf), central body diameter: 45 um, length of processes up to $25.6 \mu \mathrm{m}$. 8, 9. Glaphyrocysta divaricata (Williams and Downie, 1966) Stover and Evitt, 1978, Sample 159-959D-48R-5, 37-41 cm (866.97 mbsf), (8) D26 $(-4,-2)$, operculum breadth: $43.2 \mu \mathrm{m}$. (9) S31 $(-1,1)$, operculum breadth: $38.4 \mu \mathrm{m}$. 10. Glaphyrocysta ordinata (Williams and Downie, 1966) Stover and Evitt, 1978, Sample 159-959D-48R-5, 37-41 cm (866.97 mbsf), B25 (0, -2), operculum breadth: 36.8 m. 11. Cleistosphaeridium flexuosum Davey et al., 1966, Sample 159-959D-48R-5, 37-41 cm (866.97 mbsf), C18 (-2,-1), central body breadth: 24 m. 12, 13. Spiniferites ramosus subsp. ramosus Ehrenberg, 1838, (12) Sample 159-959D-50R-1, 105-108 cm (880.95 mbsf), C29 (1, -1), overall length: $67.2 \mu \mathrm{m}$, (13) Sample 159-959D-49R-4, 99-102 cm (875.69 mbsf), P1 $(1,-2)$, total length: $72 \mu \mathrm{m}$. 

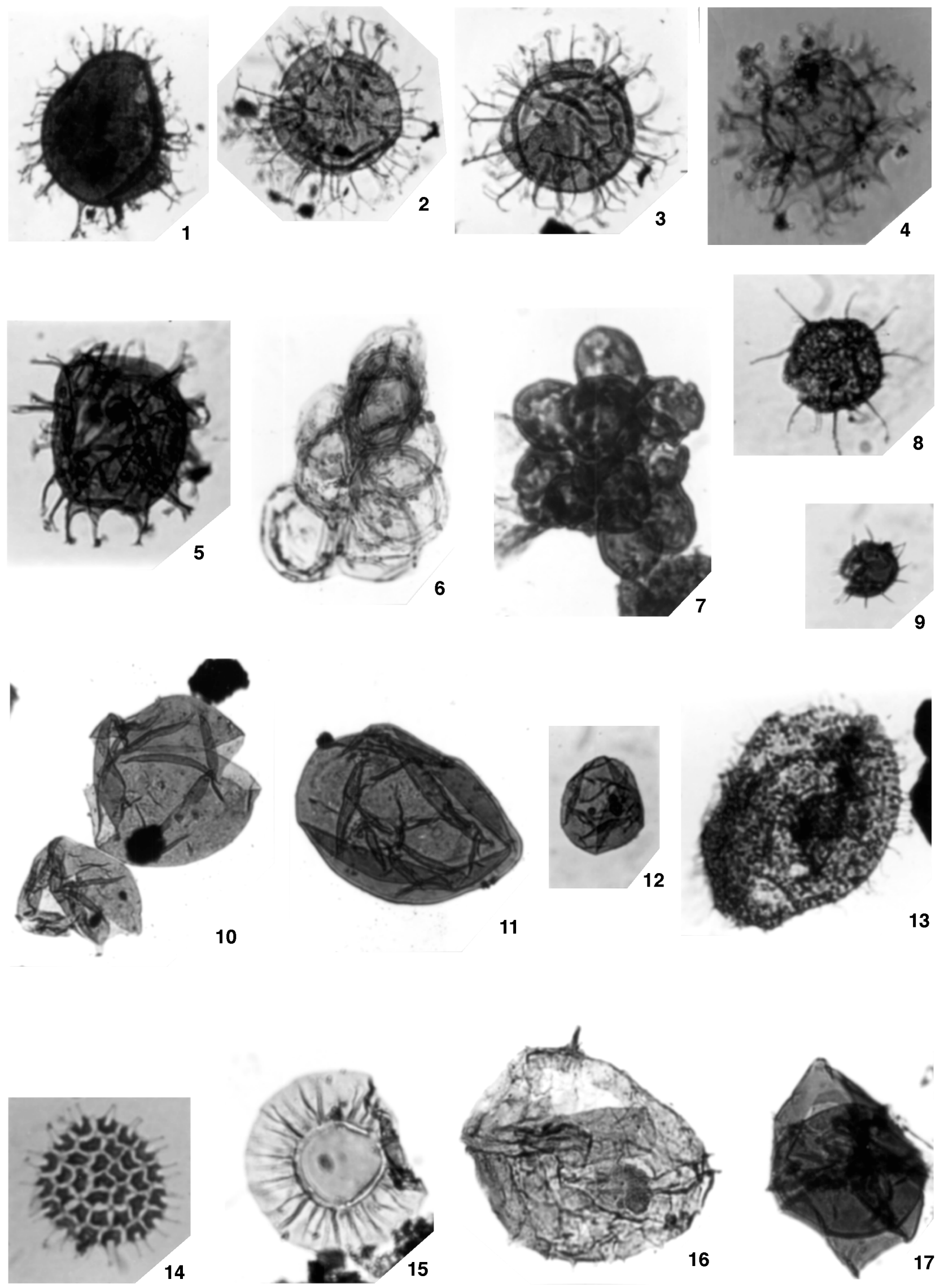
Plate 9. All specimens are from Hole 959D except Figures 16 (Hole 962D) and 17 (Hole 960A). 1. Spiniferites fluens (Hansen, 1977) Stover and Williams, 1987, Sample 159-959D-54R-1, 37-39 cm (918.47 mbsf), N20 (0, 3), central body length: $52.8 \mu \mathrm{m}$. 2, 3. Spiniferites cf. S. lenzii Below, 1982c, Sample 159959D-51R-2, 55-57 cm (891.25 mbsf), (2) M7 (0, 0), overall length: $70.4 \mu \mathrm{m}$, (3) M6 (1, 1), overall length: $75 \mu \mathrm{m} .4$. Spiniferites wetzelii (Deflandre, 1937b) Sarjeant, 1970a, Sample 159-959D-48R-5, 37-41 cm (866.97 mbsf), E33 (3.5, 3), central body breadth: $30.4 \mu \mathrm{m}$. 5. Spiniferites twistringiensis Maier, 1959 emend. Fensome et al., 1990, Sample 159-959D-67R-1, 10-14 cm (1043.4 mbsf), C12 (-4, 5), central body length: 44.8 um. 6. Palambages morulosa Wetzel, 1961. Sample 159-959D-49R-4, 99-102 cm (875.69 mbsf), F2 (-4, -2.5), average diameter of one cell in the colony: $33.6 \mu \mathrm{m}$. 7. Palambages sp., Sample 159959D-52R-01, 18-20 cm (898.98 mbsf), B34 (-2.5, 0), average diameter of one cell in the colony: $16 \mu \mathrm{m} .8$ 8, 9. Micrhystridium sp. (8) Sample 159-959D-64R5, 89-93 cm (1021.59 mbsf), M28 ( $-4,1)$, central body diameter: $20.8 \mu \mathrm{m}$, (9) Sample 159-959D-67R-1, 10-14 cm (1043.4 mbsf), M24 (-1, -3.5$)$, central body diameter: $15 \mu \mathrm{m}$. 10, 11. Leiosphoeridia sp. A, Sample 159-959D-64R-5, 89-93 cm (1021.59 mbsf), (10) K6 (-3, -4), diameter $44.8 \times 51.2 \mu \mathrm{m},(11) \mathrm{J} 21$ (1, 4), diameter: $81.6 \times 56 \mu \mathrm{m}$. 12. Leiosphaeridia sp. B., Sample 159-959D-64R-5, 89-93 cm (1021.59 mbsf), L30 (5,-5), diameter: $35.2 \mu \mathrm{m} \times 28.8 \mu \mathrm{m}$. 13. Acritarch forma A., Sample 159-959D-64R-5, 89-93 cm (1021.59 mbsf), H14/J14, length: 87.5 um. 14. Pediastrum? sp., Sample 159-960A-41R-2, 18-21 cm (352.68 mbsf), H30 (3, 5), diameter: $30.4 \mu \mathrm{m}$. length of processes: $4.8 \mu \mathrm{m}$. 15. Pterospermopsis australiensis Deflandre and Cookson, 1954, Sample 159-959D-65R-6, $10-13 \mathrm{~cm}$ (1031.70 mbsf), K34 (-3, -3), diameter: $50 \mu \mathrm{m}$. 16. Cribroperidinium cf. C. auctificum (Brideaux, 1971) Stover and Evitt, 1978, Sample 159-962D27R-1, 80-83 cm (312.10 mbsf), J15 (-2, 4), length: 84.8 um. 17. Isabelidinium cooksoniae (Alberti, 1959) Lentin and Williams, 1977, Sample 159-960A-21R$1,43-48 \mathrm{~cm}$ (184.53 mbsf), C13 (5, -5), length: $81.6 \mu \mathrm{m}$. 

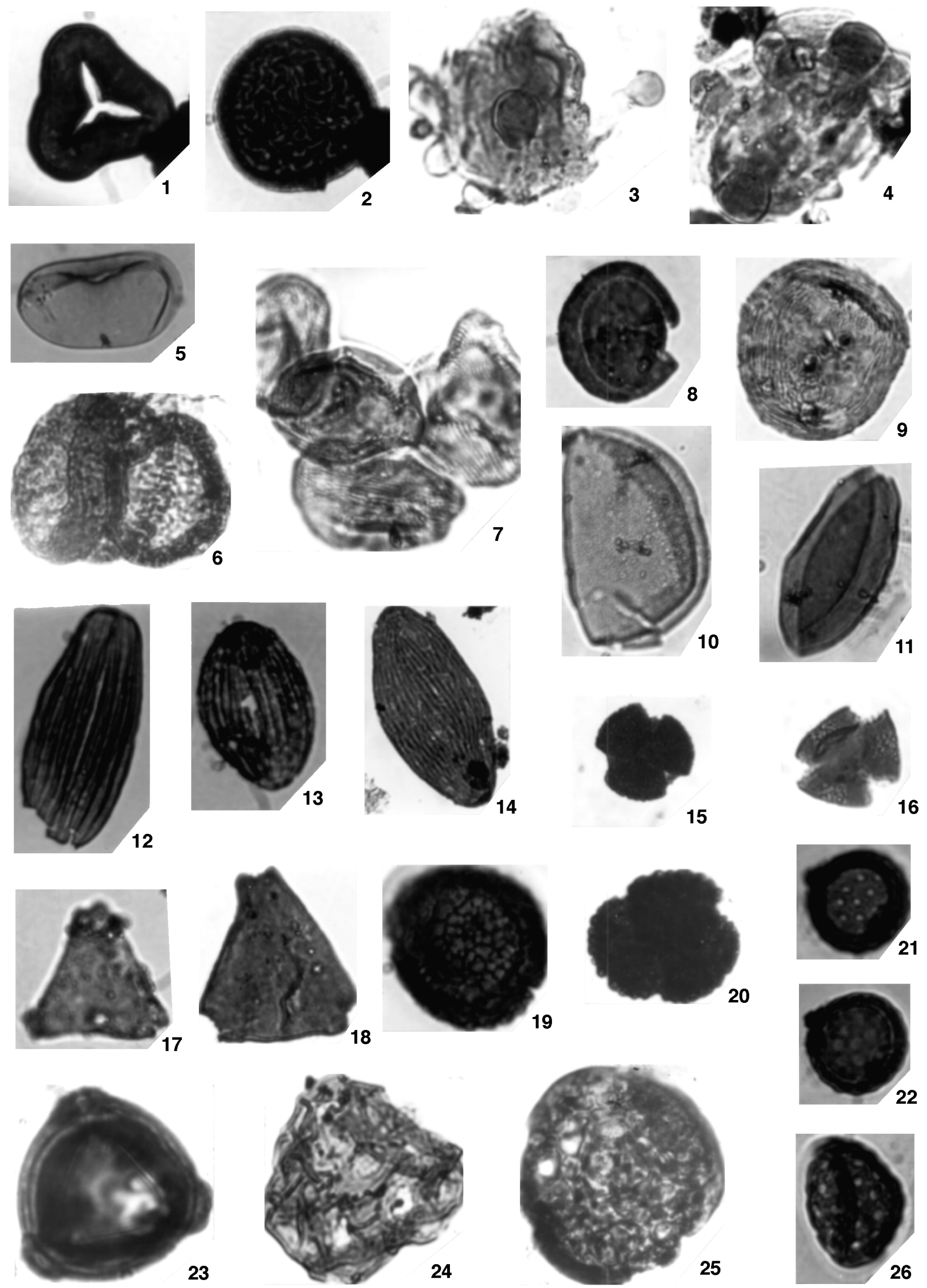
Plate 10. Selected sporomorphs from Sites 959 to 962 . Sizes quoted represent the maximum diameter or length of each specimen, unless otherwise stated. 1. Cyathidites minor Couper, 1963, Sample 159-961B-12R-1, 68-71 cm, M32/N32, size $32 \mu \mathrm{m}$. 2. Rugulatisporites caperatus van Hoeken-Klinkenberg, 1964, Sample 159-959D-60R-4, 94-96 cm, C23/C24, size 36.8 m. 3, 4. Elaterosporites castelaini Jardiné and Magloire, 1965, (3) Sample 159-962D-24R-2, 41-45 cm, L13 (0.0), size $44.8 \mu \mathrm{m}$ (central body), (4) Sample 159-962D-31R-2, 89-92 cm, J20 (-1, 3), 54 um. 5. Laevigatosporites gracilis Wilson and Webster, 1946, Sample 159-959D-48R-5, 37-41 cm, N24/N25, $64 \mu \mathrm{m}$. 6. Parvisaccites cf. P. radiatus Brenner, 1963, Sample 159-959D-49R-4, 99-102 cm, A25 (3, 2), 51.2 $\mu \mathrm{m}$. 7. Corollina torosus (Reissinger) Klaus 1955 emend. Cornet and Traverse, 1975, one tetrad, Sample 159-962D-37R-4, 81-84 cm, G6 (0, 3), 25.6 um (lowermost grain). 8. Circulina parva Brenner, 1963, Sample 159-962D-24R-2, 41-45 cm, G29 (-4, 4), $32 \mu \mathrm{m}$. 9. Corollina jardinei Herngreen, 1972, Sample 159962D-31R-2, 89-92 cm, E16 (-2, 2), $40 \mu \mathrm{m}$. 10. Longapertites vaneendenburgi Germeraad, Hopping and Muller, 1968, Sample 159-959D-48R-5, 37-41 cm, P31 $(-3,5), 60.8 \mu \mathrm{m}$. 11. Monosulcites sp. Sample 159-959D-49R-4, 99-102 cm, R4 (3, 2), $44.8 \mu \mathrm{m}$. 12. Ephedripites multicostatus Brenner, 1963, Sample

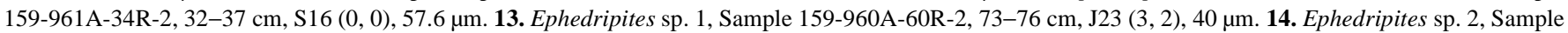
159-962D-24R-2, 41-45 cm, E34 (4, -2), 128 m. 15. Tricolpites reticulominutus Jardiné and Magloire, 1965, Sample 159-959D-67R-1, 10-14 cm, E6 (2, 4), $16 \mu \mathrm{m}$. 16. Tricolpites sp. 1. Sample 159-959D-67R-1, 10-14 cm, A3 (2, -4), $28.8 \mu \mathrm{m}$. 17. Triorites africaensis Jardiné and Magloire, 1965, Sample 159-962D-

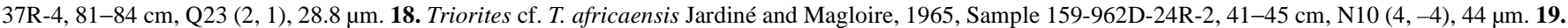
Proxapertites sp. Sample 159-959D-64R-5, 89-93 cm, T10 (1, 3), $38.4 \mu \mathrm{m}$. 20. Tricolpites sp. 2. Sample 159-959D-67R-1, 10-14 cm, C25 (4, -4), $36.8 \mu \mathrm{m} .21$, 22. Chenopodipollis sp. Sample 159-960A-21R-1, $43-48 \mathrm{~cm}$, H26/H27, $24 \mu \mathrm{m}$; (21) low focus, (22) high focus. 23. Brevicolporites sp. Sample 159-960A-59R-

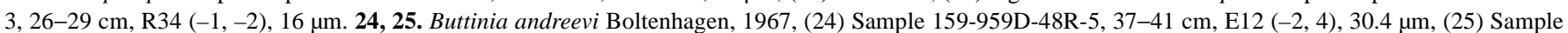
159-960A-53R-2, 29-32 cm, poorly preserved specimen, U17 (3, -4), $56 \mu$ m. 26. Multiporopollenites sp. Sample 159-962B-8H-6, 61-66 cm, A22, 28.8 $\mu \mathrm{m}$. 

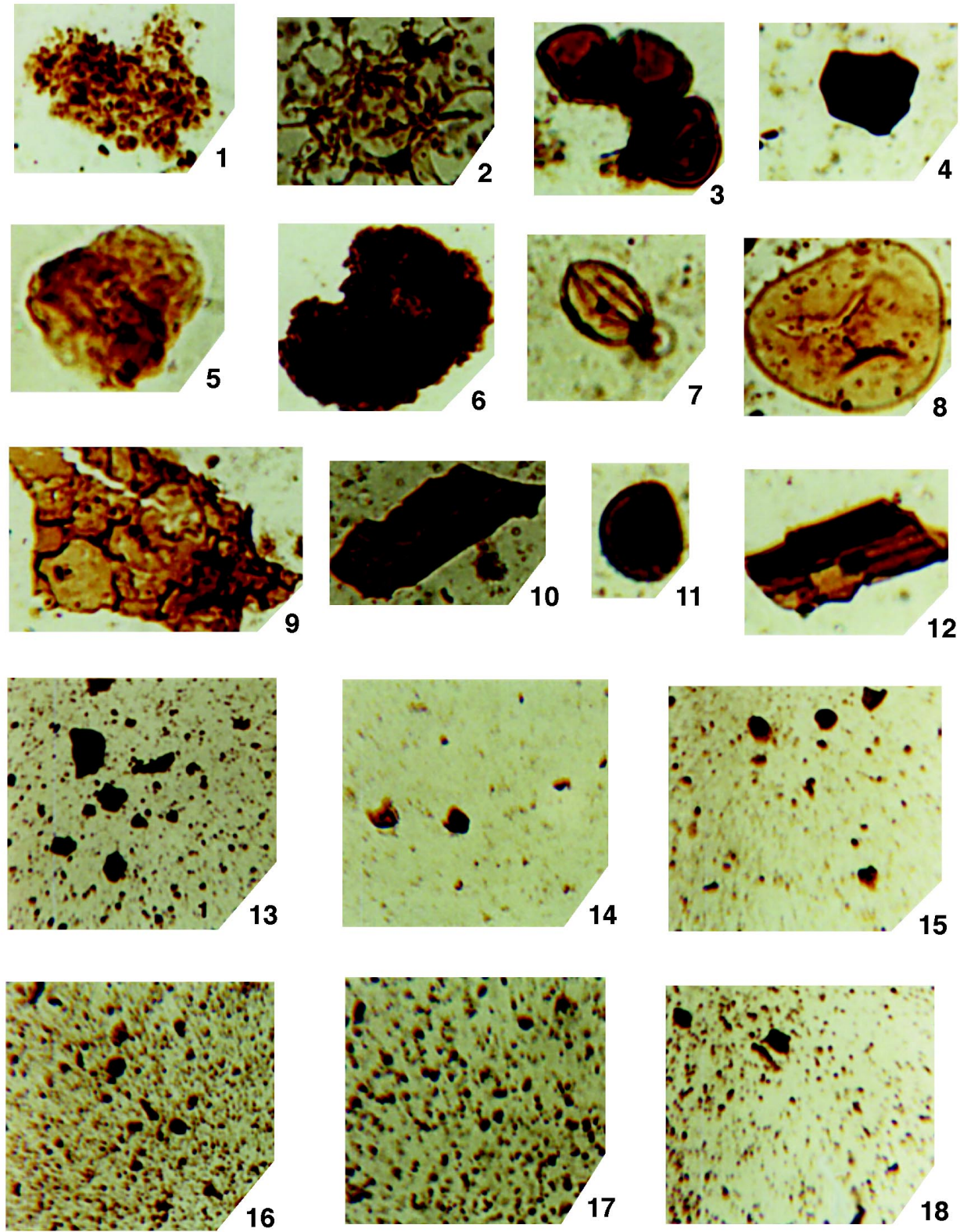

Plate 11. Some dispersed organic components used in the classification scheme (1-12), and selected palynofacies assemblages from Site 959 (13-17) and 960 (18). 1. Amorphous organic matter, Sample 159-959A-33X-2, 143-146 cm. 2. Dinoflagellate cyst, Sample 159-959D-44R-2, 4-6 cm. 3. Microforaminiferal test lining, Sample 159-959A-22X-2, 40-43 cm. 4. Black debris, Sample 159-959A-8H-2, 30-35 cm. 5. Yellow-brown fragment, Sample 159-959A-22X-2, 40-43 cm. 6. Black-brown fragment, Sample 159-959A-8H-2, 30-35 cm. 7. Tricolpate pollen, Sample 159-959A-22X-2, 40-43 cm. 8. Trilete spore, Sample 159-959A21X-3, 115-117 cm. 9. Cuticle, Sample 159-959A-19H-3, 119-124 cm. 10. Plant tissue, Sample 959A-8H-2, 30-35 cm. 11. Fungal spore, Sample 159-959A22X-2, 40-43 cm. 12. Wood, Sample 159-959A-8H-2, 30-35 cm. 13. Palynofacies Assemblage 1, Site 959 (note predominance of black debris and wood, AOM $<15 \%$ in tectonized Unit V siliciclastics), TAI values 2.6-3.0, Sample 159-959D-76R-2, 49-53 cm. 14. Palynofacies Assemblage 3, Site 959, AOM 30\%-35\% marine palynomorphs 7\%-15\%, wood and black-brown fragments $12 \%-17 \%$ each, TAI values <2.0, Sample 159-959A-22X-2, 40-43 cm. 15. Palynofacies Assemblage 4, Site 959, AOM 43\%-54\%, wood 9\%-13\%, TAI values <2.0, Sample 159-959A-18H-1, 137-142 cm. 16. Palynofacies Assemblage 6, Site 959, AOM 65\%-78\%, very rare black debris, TAI values 2.0-2.5 in some Unit III claystones, Sample 159-959D-28R-1, 121-124 cm. 17. Palynofacies Assemblage 7, Site 959, Similar to assemblage 6 except that AOM >78\%, Sample 159-959D-60R-4, 94-96 cm. 18. Palynofacies Assemblage 5, Site 960, wood and black debris $21 \%-53 \%$, AOM 0\%-36\% most of which is terrestrially derived in tectonized Unit V siliciclastics, TAI values 2.5-2.9, Sample 159-960A-59R-3, 26-29 cm. 